\title{
Overview of the Quality and Completeness of Resource Assessment Data for the APEC Region
}

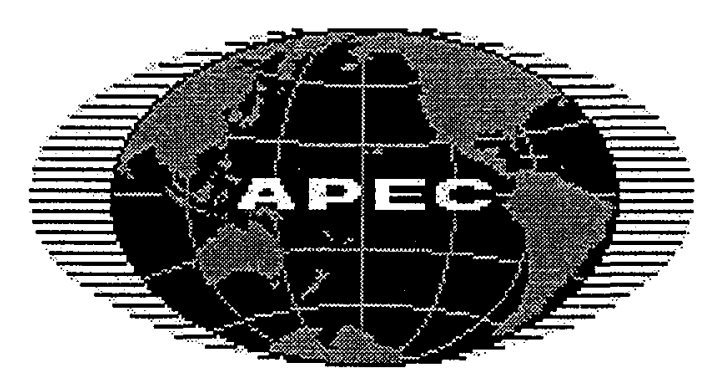

\section{ASIA-PACIFIC Economic Cooperation \\ Expert Group on New and Renewable Energy Technologies}

\author{
Prepared by: \\ David S. Renné \\ Stephen Pilasky \\ National Renewable Energy Laboratory \\ 1617 Cole Boulevard \\ Golden, Colorado 80401-3393 U.S.A. \\ February, 1998
}


Overview of the Quality and Completeness of Resource Assessment Data for the APEC Region

February, 1998

APEC \#98-RE-01.1 


\section{Table of Contents}

Table of Contents .......................................................................................................... i

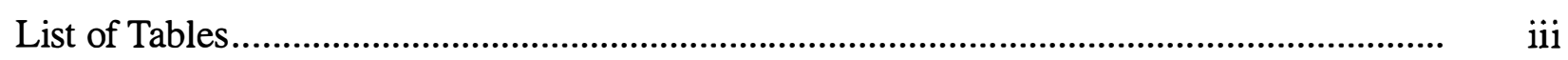

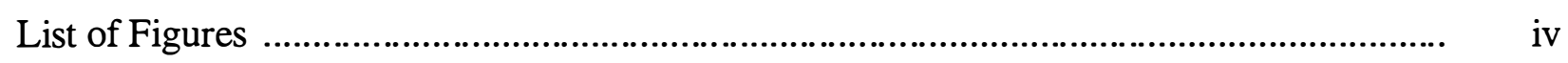

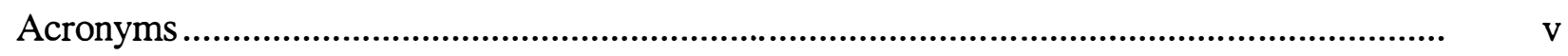

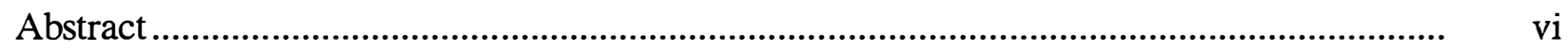

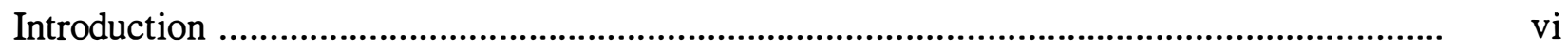

Factors Controlling Renewable Energy Resources.............................................................. vii

Climate and Atmospheric Processes .................................................................... vii

Influence of Topography and Shape of Land Mass ................................................... viii

The Value of Resource Assessment.................................................................................. ix

Approaches to Renewable Energy Resource Assessment...................................................... ix

Wind Resources .......................................................................................... ix

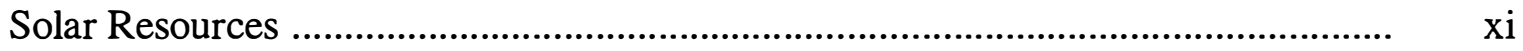

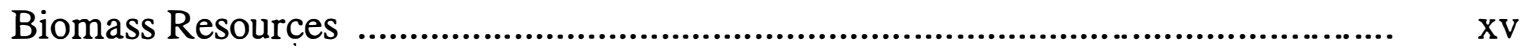

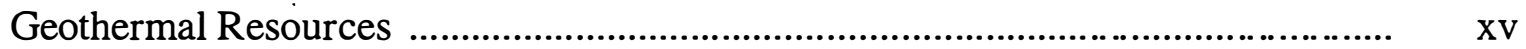

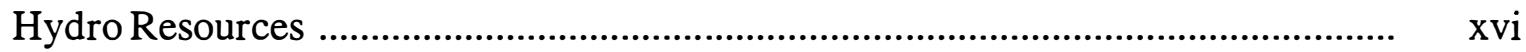

Status of Renewable Energy Resource Assessment in the APEC Region ............................ xvi

Recommendations for Improving Renewable Energy Resource Information in the

APEC Region ................................................................................................................... x xvii

References for this Section ................................................................................. xviii

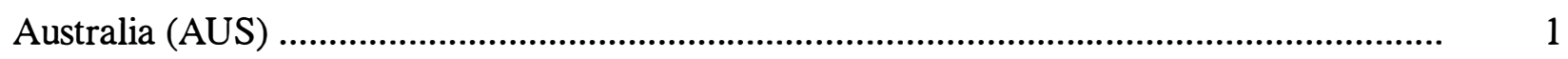

Brunei Darussalam (BD)................................................................................................

Canada (CDA) ........................................................................................................ 10

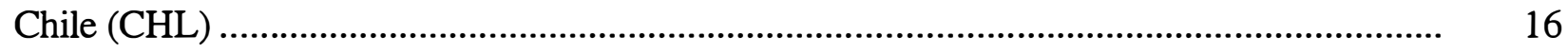

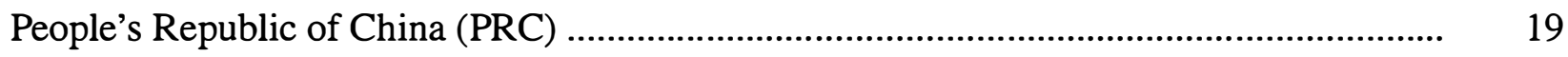

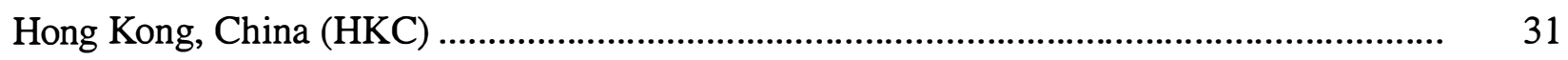

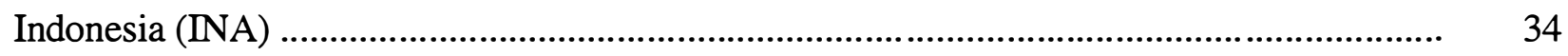

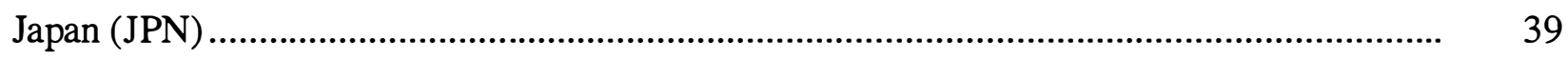

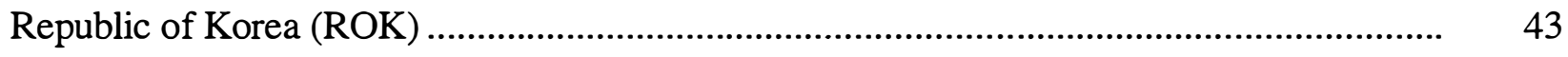




\section{Table of Contents (concluded)}

Malaysia (MAS),....................................................................................................... 46

Mexico (MEX) ........................................................................................................

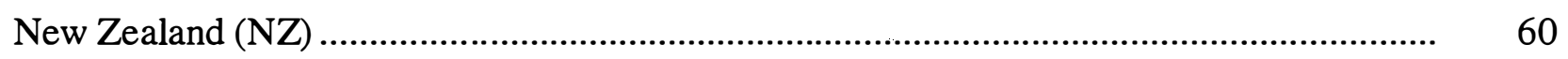

Papua New Guinea (PNG) .......................................................................................... 63

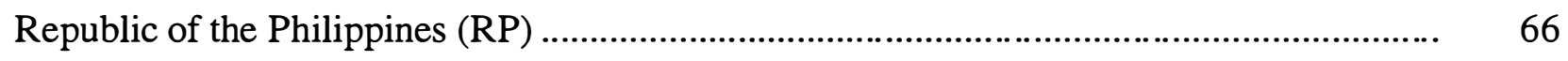

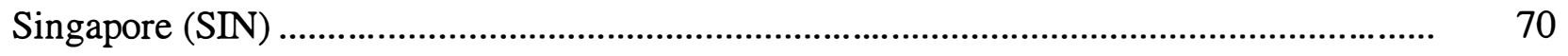

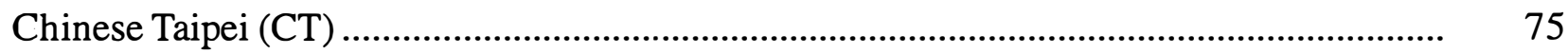

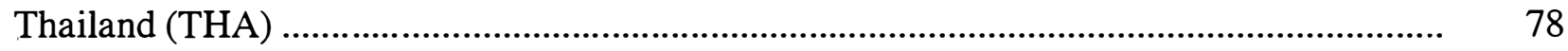

The United States of America (US) .................................................................................. 82

Appencix A: Bibliography …………………………....................................................... A-1

Appendix B: Summary Content of Bibliography Citations .................................................. B-1 


\section{List of Tables}

Table 1: Number of sites for each APEC economy that have solar radiation data available on the WRDC's World Wide Web home page (http://wrdc-mgo.nrel.gov) during at least part of the 30-year period $(1964$ - 1994)

Table 2: Number of recent publications identified for providing renewable resource assessment information in selected APEC economies.

xvii

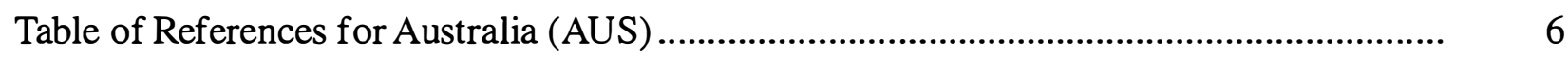

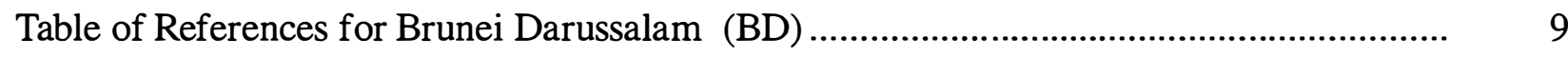

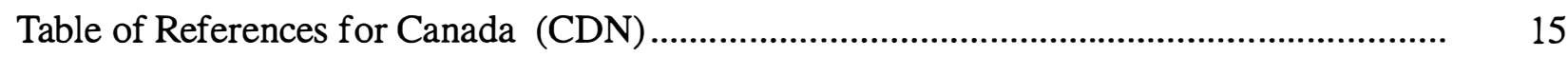

Table of References for Chile (CHL) ..................................................................... 18

Table of References for the People's Republic of China (PRC) ................................... 30

Table of References for Hong Kong, China (HKC)...................................................

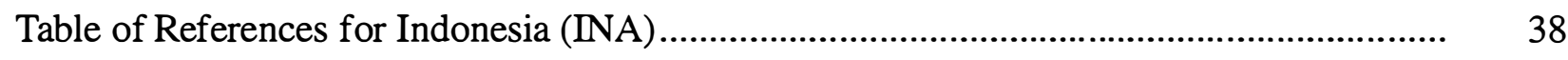

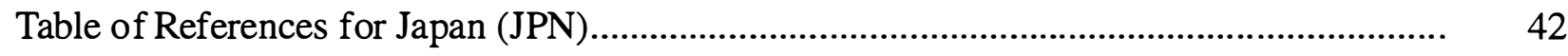

Table of References for the Republic of Korea (ROK) .................................................

Table of References for Malaysia (MAS) .............................................................

Table of References for Mexico (MEX) ............................................................. 59

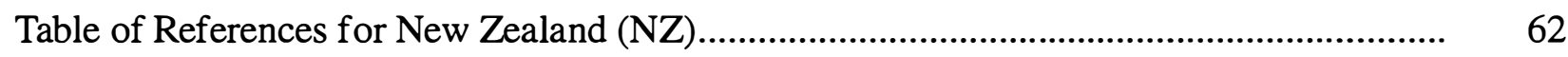

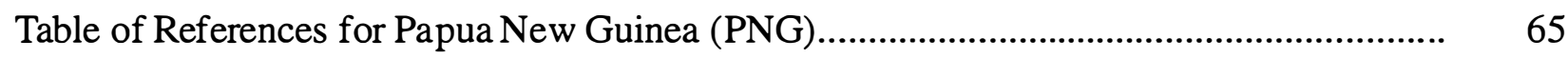

Table of References for the Republic of the Philippines (RP) .......................................... 69

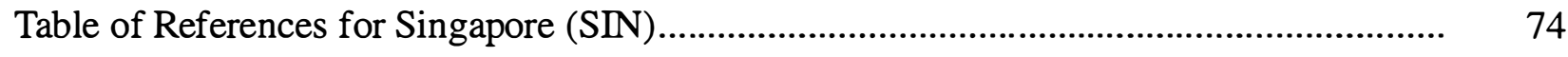

Table of References for Chinese Taipei (CT) .......................................................... 77

Table of References for Thailand (THA) .........................................................

Table of References for the United States of America (US) …..................................... 87 


\section{List of Figures}

Figure 1: Schematic showing the value of resource assessment in evaluating project performance 


\section{Acronyms}

$\begin{array}{ll}\text { AES } & \text { Atmospheric Environmental Service } \\ \text { APEC } & \text { Asia-Pacific Economic Cooperation } \\ \text { BOE } & \text { barrels of oil equivalent } \\ \text { CRIEPI } & \text { Central Research Institute of the Electric Power Industry } \\ \text { CWEEDS } & \text { Canadian Weather Energy and Engineering Data Sets } \\ \text { FERC } & \text { Federal Energy Regulatory Commission } \\ \text { HDR } & \text { hot dry rock } \\ \text { IRR } & \text { internal rate of return } \\ \text { ITCZ } & \text { Intertropical Convergence Zone } \\ \text { JMA } & \text { Japan Meteorological Agency } \\ \text { LNG } & \text { liquefied natural gas } \\ \text { LPG } & \text { liquefied petroleum gas } \\ \text { MSW } & \text { municipal solid waste } \\ \text { NES } & \text { Nonconventional Energy Sector } \\ \text { NREL } & \text { National Renewable Energy Laboratory } \\ \text { NSRDB } & \text { National Solar Radiation Data Base } \\ \text { PV } & \text { photovoltaic } \\ \text { RDF } & \text { refuse-derived fuel } \\ \text { SOLMET } & \text { solar meteorological (database) } \\ \text { SOLRAD } & \text { solar radiation (database) } \\ \text { WMO } & \text { World Meteorological Organization } \\ \text { WRDC } & \text { World Radiation Data Center } \\ \text { WTG } & \text { wind turbine generator }\end{array}$




\title{
Overview of the Quality and Completeness of Resource Assessment Data for the APEC Region
}

\begin{abstract}
The availability of information and data on the renewable energy resources (solar, wind, biomass, geothermal, and hydro) for renewable energy technologies is a critical element in the successful implementation of these technologies. This paper presents a comprehensive summary of published information on these resources for each of 18 Asia-Pacific Economic Cooperation (APEC) economies. In the introductory sections, a discussion of the quality and completeness of this information is presented, along with recommendations on steps that need to be taken to facilitate the further development and deployment of renewable energy technologies throughout the APEC region. These sections are then followed by economy-specific reviews, and a complete bibliography and summary description for each citation. The major results of this survey are that a basis for understanding renewable energy resources is currently available for essentially all the economies, although there is a significant need to apply improved and updated resource assessment techniques in most. For example, most wind resource assessments rely on data collected at national weather stations, which often results in underestimates of the true potential wind resource within an economy. As a second example, solar resource assessments in most economies rely on an analysis of very simple sunshine record data, which results in large uncertainties in accurately quantifying the resource. National surveys of biomass, geothermal, and hydro resources are often lacking; in most cases, resources for these technologies were discussed for site-specific studies only. Thus, the major recommendations in this paper are to: (1) upgrade current or install new wind and solar measurement systems at key "benchmark" locations to provide accurate, representative information on these resources; (2) apply advanced wind and solar resource assessment tools that rely on data quality assessment procedures, the use of satellite data, and models, and that can reliably interpolate the data collected at the benchmark sites; (3) conduct national surveys of biomass, geothermal, and hydro resources uniformly and consistently; and (4) establish a centralized data center that provides ready access to the most upto-date and validated renewable resource data in all APEC economies.
\end{abstract}

\section{Introduction}

The assessment of renewable energy resources involves the process of determining the potential and accessible supply of energy (wind, solar, biomass, geothermal, and hydro) available to various renewable technologies, such as wind electric, solar thermal electric, solar photovoltaic (PV), biomass (including biomass electric and alternative fuels), geothermal, and hydro and mini-hydro systems. The assessment must take into consideration the quantity and spatial and temporal characteristics of these resources, and must be able to support evaluation of grid-connected and off-grid energy conversion technologies.

Certain characteristics about renewable technologies make the assessment of energy resources available to them unique compared with conventional energy resources (for example, coal, oil, natural gas). For one, wind and solar technologies must be located at the sites where the energy supply is most favorable (technically and economically); the resource cannot be "transported" to the technology for conversion. For another, the energy source available to these technologies typically varies from time to time, and can vary from one year to the next, so that at some time the supply may not be adequate to operate the technology. And finally, the supply of renewable energy to the technology is governed by natural factors, and generally cannot be reduced or enhanced, whereas the supply of fixed stock resources available to a technology can be controlled by factors such as mining and transport rates (this supply does not necessarily apply to biomass 
resources, which generally must be transported to a conversion facility, or to hydro resources, where the energy resource can be stored for later conversion).

Because of the temporal and spatial variability of renewable energy resources, the assessment methodologies must account not only for evaluations of data sources in regions where data is available, but also for estimates of the resource over regions and time periods where there is no data. Thus, a complete evaluation of renewable energy resources involves not only a study of the suitable data sets, but also the application of techniques to extrapolate available data or to estimate resources over regions where data is limited or lacking. After reviewing the factors that influence renewable energy resources, general approaches for conducting these assessments are presented, with particular emphasis on applying the assessment techniques in the APEC economies. Recommended approaches for improving this information are presented. Finally, a summary of the information on renewable energy resources for each economy based on the literature review is presented, followed by a complete bibliography and an appendix that highlights the nature of information included in each citation.

\section{Factors Controlling Renewable Energy Resources}

The amount and characteristic of all renewable energy resources are determined to a large extent by the climate, topography, and other natural features of a region. The influence of these features on renewable energy resources in the APEC region is described in this section.

\section{Climate and Atmospheric Processes}

The 18 economies of the APEC region included in this study (Australia; Brunei Darussalam; Canada; Chile; People's Republic of China; Hong Kong, China; Indonesia; Japan; Republic of Korea; Malaysia; Mexico; New Zealand; Papua New Guinea; Republic of the Philippines; Singapore; Chinese Taipei; Thailand; and the United States of America) encompass a large geographic region around the Pacific rim that includes a wide range of climatological and topographic features, and spans both the northern and southern hemispheres. Climatic regimes include virtually all possibilities, such as arctic, temperate, subtropical, tropical, maritime, and continental. As a result of this diversity, the availability of renewable energy resources is highly variable in the APEC region. Some generalizations about the potential renewable energy supply for various climatic regimes around the region are provided here. These generalizations, nevertheless, do not forego the need to conduct actual assessments of resources for specific regions using available data and advanced assessment techniques.

The general circulation of the atmosphere and large-scale currents in the Pacific Ocean are the predominant climatic features that control the availability of wind, solar, biomass, and hydro resources in the APEC region. The subtropical regions, which generally extend from $10^{\circ}$ to $35^{\circ}$ latitude, are dominated by a large anticyclonic (high-pressure) system, particularly over the eastern Pacific Ocean in both the northern and southern hemispheres. These anticyclonic features are particularly strong during the summer months over the eastern part of the ocean, where water temperatures are much cooler than adjacent land temperatures, but can generally be found throughout the subtropical latitude belts. The climate associated with these subtropical highpressure systems generally consists of sunny skies and relatively light winds, disturbed only occasionally by westward-moving cyclones passing through the region. These high-pressure systems are a primary reason why deserts occur over much of the western portion of subtropical land masses on the eastern side of the ocean (for example, the Mojave desert in the United States and Antofagasta desert in Chile), where some of the best solar resources generally occur, but where biomass resources are limited. 
On the equatorial side of these high pressure systems are the persistent westward-flowing "trade winds." These result in ideal wind resources over many subtropical regions, particularly on the western side of the ocean, such as in the Philippines, Indonesia, and northern New Zealand.

Closer to the equator, the outflow from these large-scale anticyclonic systems converges, causing rising warm air and, consequently, frequent clouds and heavy rainfall. This band of cloudiness and rainfall is known as the Intertropical Convergence Zone (ITCZ). Along with the anticyclonic systems, the ITCZ migrates northward and southward with the seasons, resulting in the familiar wet and dry monsoonal climate of many tropical regions, particularly on the west side of the Pacific Ocean. In these equatorial regions, solar resources are abundant for part of the year. Wind resources are typically low, although good resources can be found in local areas such as along shorelines, and surveys should be conducted. Because of the warm, moist climate, most of the world's tropical rain forests are in this region, and therefore biomass resources are most abundant. Most APEC members that lie in the tropical regions extending approximately from $20^{\circ} \mathrm{S}$ to $20^{\circ} \mathrm{N}$ have strong monsoonal climates, particularly on the west side of the Pacific Ocean.

On the mid-latitude side of the subtropical anticyclones $\left(30^{\circ}\right.$ to $\left.50^{\circ}\right)$, the warm outflowing air meets the colder air moving equatorward from the arctic and subarctic regions, resulting in the highly variable climate that is so characteristic of the temperate, mid-latitude zone. This region is characterized by frequent storms moving west to east, particularly during December, January, and February, and strong seasonal variability in climate. Thus, wind, solar, biomass, and hydro resources can all be abundant during certain seasons. Wind resources can be very good in arctic regions.

\section{Influence of Topography and Shape of Land Mass}

In all cases, local topography and the proximity to large bodies of water will significantly influence the availability of wind, solar, biomass, and hydro resources. Even in moist tropical belts, localized deserts can be found because of topographic characteristics; abundant rainfall can occur in portions of the normally arid subtropical regions, again because of topography or landsea contrasts. The geology and topography also dictate optimal locations for geothermal resources.

The unique relationships among the location of APEC members with respect to the Pacific Ocean are major factors in determining optimum locations of wind, solar, hydro, biomass, and geothermal resources. The large-scale weather patterns result in a northward-moving warm water current on the west side of the Pacific Ocean, and a flow of cooler water toward the equator on the east side. These currents result in strong land-sea temperature contrasts on both sides of the Pacific, which influence climate and thus the availability of certain renewable resources in specific regions. For example, the relatively cool water in the subtropical eastern Pacific acts to suppress cloudiness and rainfall, accentuating the desert-like characteristics of the west coasts of North and South America. The relatively warm currents on the mid-latitude western Pacific contrast with the cold air flowing off the Asian land mass, resulting in frequent storms in the mid-latitude regions, such as eastern China, Korea, and Japan. Further inland, however, the climate of APEC regions such as central and western China, central Australia, and central United States and Canada, is more "continental" in nature, resulting in large regions of potentially excellent solar and wind resources.

Topographic features such as mountain ranges, ridge crests, and shorelines can significantly alter the regional characteristics of solar and wind resources, and the distribution of rainfall that affects hydro and biomass resources. Ridge crests can greatly accelerate wind flow and enhance cloudiness on the upwind side. Local winds can be quite strong where land-sea contrasts occur, 
even in regions where the general wind flow is light. Thus, a major challenge in assessing renewable energy resources is to take into consideration these localized features and how they influence weather patterns, since actual data in these regions is often lacking.

Because of the active seismicity of the Pacific region, numerous geothermal wells have been identified, and untapped geothermal resources are likely to be plentiful.

\section{The Value of Resource Assessment}

Proper assessment of renewable energy resources can go a long way toward advancing and accelerating the deployment of renewable technologies. Figure 1 shows a hypothetical relationship between the expected resource at a site and the internal rate of return (IRR) of a renewable project. The figure indicates two critical factors on the importance of an accurate knowledge of the renewable resource at a proposed site or region. One factor is related to the uncertainty in the true knowledge of the resource. If there are no on-site measurements at the proposed project site, the estimate of the resource can easily deviate by $\pm 10 \%$ or more of the true value. The figure shows that, if this is the uncertainty of the resource at this proposed project site, the lower estimated value would actually be below the "hurdle rate" (the minimum IRR the investors must earn from a project) of this project. By being able to demonstrate that the resource uncertainty is only $\pm 5 \%$, either through on-site monitoring or through more improved resource estimation techniques, the proposed project will always be above the hurdle rate, and the confidence of the investors will be enhanced. A second critical factor that can be seen from the figure is that the process of "prospecting" for better resource sites offers a greater and greater IRR on the project.

Another important factor is the interannual variability of the resource. Again, we can refer to Figure 1 to see how the resource variability from year to year affects the IRR of a project. Because average annual wind and solar resources can vary by $\pm 10 \%$ from year to year, in some years the resource may fall below the level necessary to maintain the "hurdle rate." For example, a significant natural event, such as the eruption of Mount Penatubo in the Philippines in 1991, can have a significant impact on solar resources for several years throughout many parts of the APEC region. These are important considerations for investors to take into account when evaluating the long-term cash flow and viability of a renewable energy project. This also shows how important the proper, long-term evaluation of the resource is to project planning, and therefore to the success of the renewable energy industry.

\section{Approaches to Renewable Energy Resource Assessment}

The approaches used to assess renewable energy resources differ depending on the technology, and can depend on specific types of technologies within each category. Thus, in this section we outline the general approach that is typically taken for each of the technology categories.

\section{Wind Resources}

Because wind resources are so highly variable, even in specific locations where there is complex terrain or other unique geographic features, the assessment of these resources is probably the most complex and challenging of all the renewable technologies. The approach for large-scale regional wind resource assessment has generally been as follows in most APEC economies where assessments have been conducted: 


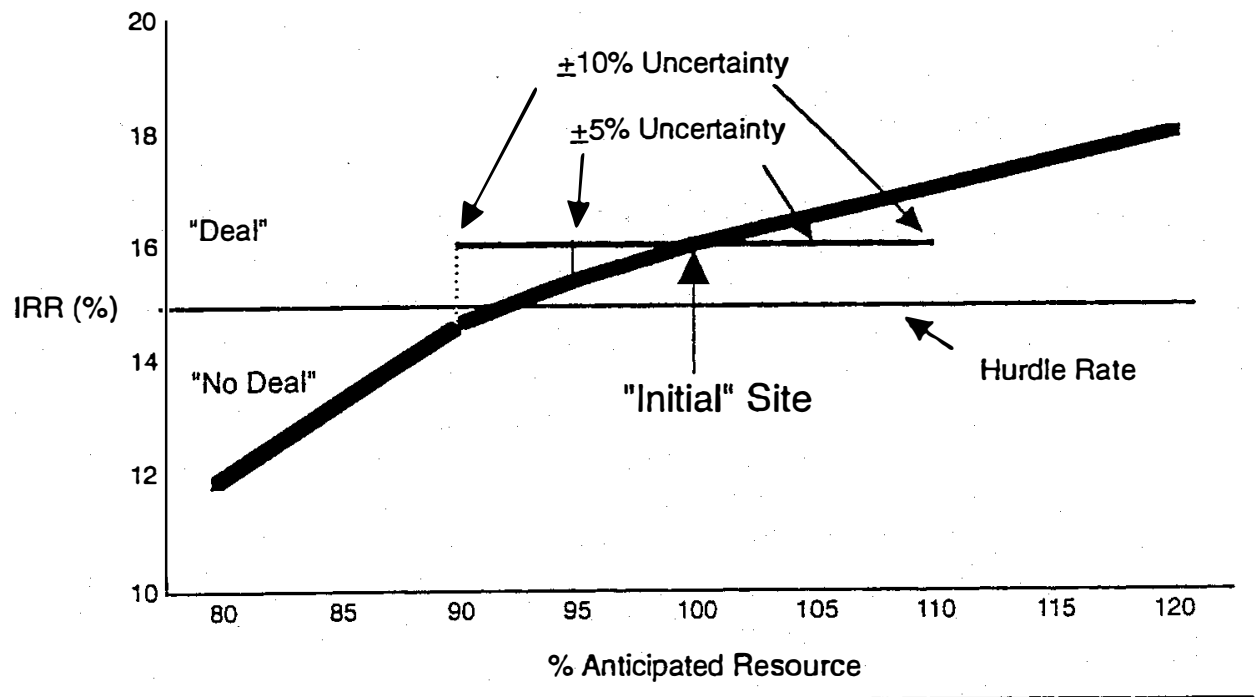

(IRR = Internal Rate of Return)

\section{Figure 1: Schematic showing the value of resource assessment in evaluating project performance}

- Gather available meteorological data, usually from weather and climatological stations typically operated by national meteorological services in individual APEC economies.

- $\quad$ Because wind speeds generally increase with height, make appropriate adjustments to the data, which is usually collected at heights of approximately $10 \mathrm{~m}$ above the ground, to the height of the hub of typical modern-day wind machines (10-40 $\mathrm{m}$ or more).

- $\quad$ Convert the frequency distribution of the hourly wind speed values (or, conversely, if only long-term mean wind speeds are available, apply a mathematical approximation to the wind speed distribution, such as a Weibull distribution) into an average wind power or wind power class, as described in [1].

- Display the monthly or annual wind power values or classes on maps of the region.

This approach results in the most basic wind resource assessment for a region; however, although this approach offers useful first-order approximations, significant uncertainties and misrepresentations of the true extent and nature of the resource could result if no further analytical techniques are taken. This is due to several factors:

1. Most weather observing stations are located near populated regions, which are not necessarily in the best wind resource regions. This factor would generally result in an underestimate of the true level of wind resources and their location in a region. 
2. Because these weather stations are near populated regions, the wind measuring device (anemometer), which may have at one time been installed in a relatively open space, may be influenced by nearby buildings or vegetation. This would invariably result in lower wind speed observations over time and no longer be representative of the true wind speed in the region.

3. The quality of data could have deteriorated for other reasons, such as poor anemometer maintenance, resulting in incorrect (and generally lower) wind speed observations over time.

4. Certain topographic features or coastal regions can significantly enhance wind speeds that are not being monitored at the wind stations or captured adequately in the height adjustments, and therefore be entirely missed in the regional assessments.

5. Other data sources, such as wind measurements above the ground obtained from weather balloons, satellite-derived estimates of winds over open water surfaces, and special wind measurements not archived by the meteorological services, are not included in the surveys.

6. Advanced techniques, such as wind mapping over complex terrain, or inclusion of indicators of good resources that could result in the identification of regions of high wind resources that would be missed using available data sets, have not been applied.

\section{Solar Resources}

Three components make up solar resource information: global horizontal solar radiation, diffuse, and direct normal solar radiation. Global horizontal solar radiation is a measure of the total radiation of the sun and sky falling on a surface horizontal to the earth's surface. This category of solar energy is used as the basis for assessing the energy available to solar collectors such as PV systems. Diffuse radiation is that portion of the global horizontal that is attributed only to the sky and clouds, with the contribution from the sun removed. Along with global horizontal radiation, diffuse radiation is relatively easy to measure. The direct normal resource is a measure of the energy directly from the sun falling on a surface that is always oriented toward the sun. This information is important for solar collectors used in certain solar thermal systems where the radiation from the sun is of primary importance, but is a difficult measure to make directly.

The assessment of solar resources usually begins with the same approach as the assessment of wind resources: the evaluation of solar radiation data collected at national meteorological services in individual economies. However, unlike wind resources, global horizontal solar radiation is generally measured in only a few locations within an economy, although most economies in the APEC region maintain at least a limited network of these measurements. Because of the difficulty of measuring direct normal resources, quality measurements of this parameter are even scarcer (in cases where diffuse measurements are also made, the direct normal resource can be calculated from the global horizontal and diffuse measurements). Although global horizontal solar resources do not experience the spatial variability that is characteristic of wind resources, the limited number of solar measurements adds considerably to the uncertainty of the resulting assessment. In addition, direct normal radiation is much more site-specific than global horizontal. Thus, there are many challenges in conducting a quality solar resource assessment.

Because the primary influence on solar radiation at the earth's surface (other than the diurnal cycle) is cloud cover, many efforts have been made to convert cloud cover information into solar 
resource estimates. Hourly or 3-hourly cloud cover observations are generally taken at most firstorder national meteorological service stations, so the coverage of this information is far more extensive than for actual solar measurements. In additional, many stations throughout the world have employed various instruments to measure sunshine duration. For example, one commonly used instrument, the Campbell-Stokes radiometer, measures the number of direct sunshine hours in a day by focusing the solar beam through a glass ball onto a strip of paper. The focused beam burns through the paper when the sun is not obscured by clouds. At the end of each day, the weather observer uses a special ruler to relate the length of the burn marks to the number of hours during the day that direct sunlight occurred. Empirical relationships have been developed to convert this information into estimates of the daily total global horizontal solar resource.

Most solar assessments that have been conducted in the APEC region, as well as in most of the rest of the world, have relied on cloud cover or sunshine duration as a basis for the assessment. The little available data is used primarily to verify the empirical methods used to develop the estimates from the cloud cover data or sunshine records. In the United States, for example, the National Solar Radiation Data Base (NSRDB) that was recently completed by the National Renewable Energy Laboratory (NREL) [2] consists of approximately $95 \%$ modeled data using the cloud cover observations from 239 weather service stations throughout this economy. Only about 50 of these stations ever conducted actual solar global horizontal or diffuse measurements, and even then, only for a portion of the 30-year period that the database covers. Far fewer stations actually took direct normal measurements during any part of this time period.

These shortcomings have recently spawned a number of efforts to convert data collected from weather satellites to surface solar radiation estimates. A number of techniques have resulted, particularly making use of the geostationary weather satellites that surround the earth. A review of these approaches is beyond the scope of this paper. However, regional solar resource surveys use satellite data for the APEC region. For example, the National Aeronautics and Space Administration Langley Research Center located in the United States has produced a worldwide surface radiation budget data set for the period 1985-1988 as part of the World Climate Research Program [3]. This data set includes surface daily total and monthly averages of the daily total global horizontal solar resource on grid squares approximately $280 \mathrm{~km}^{2}$ to a side. The length of the data set is currently being extended to 8 years. This information allows for a more consistent regional survey of solar resources than is possible by converting sunshine records or cloud cover observations. However, it is difficult to develop direct normal resource estimates from this type of information.

Another advanced assessment approach is to develop models of surface solar resources (all three components) from cloud cover data measured directly from satellites. Recently a 20-year database of worldwide cloud cover data reported on a 3-hourly basis, known as the Real Time Nephanalysis [4] was made available in the United States. Daily summaries of this information are also available for a 10-year period. This database actually represents a merging of satellite cloud cover measurements with surface cloud cover observations. Efforts are currently underway at NREL to develop monthly average daily total solar resource information on a $40-\mathrm{km}$ grid for any location on earth using this data set [5].

Although approaches using satellite data offer a promising way for upgrading solar resource assessments based on the few surface measurements and the conversion of cloud cover or sunshine records to estimated values, they have not yet been rigorously applied to any of the APEC members or to the region as a whole. However, there are two comprehensive sources of solar information for the APEC region. One is the worldwide survey of solar resources based on a literature review of solar resource assessments that generally relied on sunshine records, published by the University of Massachusetts at Lowell in the United States [6]. The other is the 
worldwide solar radiation data base accessible through the World Radiation Data Center (WRDC) in St. Petersburg, Russia [7].

The WRDC, an office of the Main Geophysical Observatory in St. Petersburg, Russia, was established in the 1960s by the World Meteorological Organization (WMO) as an archive and distributor of solar radiation data collected by national meteorological services and other agencies throughout the world. As stated earlier, most economies maintain some level of solar radiation monitoring, where direct measurements of the global horizontal solar resource (and in some cases the direct normal and/or the diffuse components) are collected at one or more locations, usually at a national meteorological service office. Under the auspices of the WMO, many of these stations have been voluntarily submitting copies of this data to the WRDC for archive and eventual dissemination. Thus the WRDC has become a central archive for daily total and, in a few cases, hourly solar radiation for as many as 1100 stations around the world (the current number is around 700). The WRDC staff performs additional quality assessments of the data received from the national services, and periodically (typically, every 3 months), publishes the solar data, and distributes the reports to subscribers around the world.

In recent years, funding constraints have prevented the WRDC from maintaining all the quality assessment, archival, and information dissemination functions, and it fell behind in report distribution. Then in 1992 several U.S. government agencies offered technical assistance to the WRDC, and in 1993 NREL, under sponsorship of the U.S. Department of Energy and with technical assistance from the WMO, worked with WRDC staff to install an updated computer system in its offices, and establish an internet link so the data archives could be placed on the World Wide Web home page for access to anyone with an internet link and a web browser. This assistance also allows the WRDC to resume the publication and distribution of the data reports.

Approximately 18 years of data from the 30 -year data archive are currently available on the World Wide Web home page (http://wrdc-mgo.nrel.gov). Table 1 provides a list of APEC economies that have at least one data station on this electronic archive, and the number of stations available for each economy. By accessing this home page, users can also determine the latitude, longitude, elevation, and years of record for each station, and pull up monthly lists of the daily total global horizontal solar radiation for each station.

Two important points to note here are: (1) many of the national solar resource surveys available in the literature may have already included the data from some of these stations for at least part of the period of record in their assessments; and (2) many additional solar measurement data sets may be available within each economy that were never submitted to the WRDC archives. 
Table 1: Number of sites for each APEC economy that have solar radiation data available on the WRDC's World Wide Web home page (http://wrdc-mgo.nrel.gov) during at least part of the 30-year period (1964-1994)

\begin{tabular}{|l|c|}
\hline \multicolumn{1}{|c|}{ APEC Economy } & Number of Sites \\
\hline \hline Australia & 79 \\
\hline Brunei Darussalam & 1 \\
\hline Canada & 60 \\
\hline Chile & 73 \\
\hline People's Republic of China & 10 \\
\hline Hong Kong, China & 1 \\
\hline Indonesia & $5^{\mathrm{a}}$ \\
\hline Japan & 18 \\
\hline Republic of Korea & 4 \\
\hline Malaysia & 5 \\
\hline Mexico & 4 \\
\hline New Zealand & 9 \\
\hline Papua New Guinea & 3 \\
\hline Republic of the Philippines & 1 \\
\hline Singapore & 1 \\
\hline Chinese Taipei & 0 \\
\hline Thailand & 4 \\
\hline United States of America & $66^{\mathrm{b}}$ \\
\hline
\end{tabular}

a. Including Dilli Airport on East Timor

b. Including a station on Honolulu, Hawaiian Islands.

There are several advantages of using this source to assess the solar resources in a specific region. One, because all the data collected by the national services generally follows WMO internationally accepted guidelines and calibration procedures, and because all data is quality assessed at the WRDC and within the host economy, the quality of the information is generally acceptable. Another is that, in cases where national solar resource assessments have not yet been 
conducted or have not included data from measurement stations, the access to this data has now been made much easier through the World Wide Web home page.

\section{Biomass Resources}

Biomass is the most complex of the renewable energy resources, and its assessment is generally the most difficult. This is due to the multiple sources of biomass being considered for energy conversion, including energy crops (trees, corn, algae, etc.), standing crops grown for other purposes, such as forests, forest litter and standing waste, crop residues, waste materials from mills, animal manure, and municipal solid waste (MSW). Individual attention to each of these categories is necessary for proper assessment. The resource to be assessed is usually specifically related to the conversion technology.

The assessment of these resources is further complicated by the fact that there is little consensus on how much of the energy contained in the material is actually available for energy conversion. This is because there is competition for many of these materials for other uses, such as food and clothing, or for use of the waste material to replenish the soil.

Efforts to inventory various categories of biomass energy resources have been attempted, usually within certain locales. Oftentimes, national statistical databases are used to extrapolate field surveys or inventories to some form of national assessment. For example, measures of crop residue available for biomass energy follow a two-step process. First, residue factors must be determined, by comparing crop weights with residue weights. Then, estimates of the total resource are determined by multiplying the residue factors with production statistics, which are generally available through government ministries. The most basic level of biomass resource assessment in a given economy generally uses these national statistiçs in association with production factors available in the literature. More advanced techniques of ten follow a procedure of developing in situ production factors within the economy, and applying statistics to these factors.

\section{Geothermal Resources}

Geothermal resources occur in a variety of geologic environments, most commonly in regions of volcanic activity or geologic faults. The assessment of geothermal resources can be a costly and timely process, it involves a number of complex tests. Identifying specific reservoirs that represent a potential energy supply (based on the volume and depth of water, and water temperature, pressure, and chemical characteristics) can significantly add to these costs.

Generally, the assessment of geothermal resources follows two major steps. First, regions of potential geothermal activity must be identified. This is generally done through observations of surface phenomena such as geysers and outcrops. Use of aircraft photography or satellite imagery, thermal infrared scanners, resistivity and magnetotelluric surveys, and knowledge of subsurface geology, can also help identify regions of potential geothermal activity.

Second, exploratory drilling of promising areas is generally required. Data from these wells is analyzed to determine the depth, chemistry, temperature, and pressure of the water or steam, or both. For example, shallow temperature-gradient holes might be drilled in a promising region to better characterize any thermal anomaly. Stratigraphic test holes might be drilled in those areas thought to have the greatest potential. Test wells might even be used to test the potential yield of a promising reservoir. 


\section{Hydro Resources}

Hydropower resources, at least for large-scale projects, have been surveyed throughout most of the APEC region. These surveys fundamentally involve the conversion of streamflow data and run-of-river characteristics into the total hydraulic head for a given watershed. In many cases, however, these surveys may not be adequate for, or may not have focused on, potential mini-hydropower projects, so further assessment is generally required here.

The major issues associated with hydropower assessments are not only the physical characteristics of the watershed and the availability of streamflow data, but also the policy and institutional issues within an economy that could limit future hydropower development. Increasing awareness of the environmental issues, loss of agricultural production, and displacement of populations places significant constraints on large-scale hydropower development throughout much of the world. These issues may not be as restrictive for mini-hydro development, however.

\section{Status of Renewable Energy Resource Assessment in the APEC Region}

For this report, a survey of renewable energy resource assessment studies in the APEC region was conducted, using electronic library search techniques as well as interviews with in-economy experts. The electronic search has yielded an abundant list of publications on renewable energy resources, as shown in Table 2. In some cases, the reports provide results of research at specific sites or regions within an economy; on the other hand, reports are also being identified that give a multi-national perspective on potential renewable energy supply. The remaining sections of this report provide a summary of the findings in this library search for each APEC economy. Appendix A provides the complete bibliography of publications resulting from this search. Appendix B provides a synopsis of the type of information available in each publication.

Some further explanation of the information provided for each economy in the following sections is provided here. A referencing scheme has been established in which reports for each technology within each economy are referenced according to the economy (initial abbreviation) and the technology (W for wind, $\mathrm{S}$ for solar, $\mathrm{B}$ for biomass, $\mathrm{G}$ for geothermal, and $\mathrm{H}$ for hydro). In some cases, the reports are more general, and are designated as an $\mathrm{N}$ for general. A reference table is provided at the end of each economy's summary; the complete reference can be found in Appendix A. A few references are listed in Appendix A that are not actually cited anywhere in the text, because the information is either redundant to other references, or did not exactly fit into the scope of this paper.

In each economy write-up, several adjustments were made to the original references. First, to the extent possible, units are converted to commonly used metric units. In the case of solar resources, for example, units were converted to $\mathrm{kWh} / \mathrm{m}^{2}$-day and to $\mathrm{W} / \mathrm{m}^{2}$, to the extent possible. However, when figures, taken from the original reports, are reproduced (to give the reader a better indication of the type of information available for each economy), the original units are shown, along with a conversion factor in the figure caption.

In many cases key information about the measurement systems used in a citation is not available. For example, the height of the anemometer for wind energy surveys is often not listed. Only when this information is available is it indicated in the text; that is, if the anemometer height is not provided in the summary sections, this is because it was not listed in the original reference.

If no reference to a particular technology was found for a given economy, no discussion regarding that technology is provided here. 
Table 2: Number of recent publications identified for providing renewable resource assessment information in the 18 APEC economies.

\begin{tabular}{|l|c|c|c|c|c|c|}
\hline \multicolumn{1}{|c|}{ APEC Economy } & Wind & Solar & Biomass & Geothermal & Hydro & General \\
\hline \hline Australia & 4 & 5 & 2 & 2 & 1 & 5 \\
\hline Brunei Darussalam & 0 & 3 & 0 & 0 & 1 & 4 \\
\hline Canada & 2 & 8 & 3 & 2 & 3 & 7 \\
\hline Chile & 4 & 5 & 0 & 0 & 0 & 1 \\
\hline People's Republic of China & 10 & 10 & 1 & 1 & 0 & 7 \\
\hline Hong Kong, China & 0 & 6 & 0 & 0 & 0 & 1 \\
\hline Indonesia & 2 & 1 & 1 & 3 & 0 & 4 \\
\hline Japan & 10 & 6 & 0 & 7 & 0 & 4 \\
\hline Republic of Korea & 1 & 3 & 0 & 1 & 0 & 5 \\
\hline Malaysia & 2 & 5 & 0 & 0 & 1 & 1 \\
\hline Mexico & 1 & 9 & 0 & 3 & 0 & 3 \\
\hline New Zealand & 4 & 1 & 3 & 1 & 1 & 0 \\
\hline Papua New Guinea & 0 & 3 & 0 & 0 & 3 & 2 \\
\hline Republic of the Philippines & 0 & 0 & 2 & 7 & 0 & 1 \\
\hline Singapore & 0 & 5 & 1 & 0 & 1 & 1 \\
\hline Chinese Taipei & 1 & 1 & 1 & 1 & 2 & 3 \\
\hline Thailand & 2 & 8 & 1 & 0 & 3 & 7 \\
\hline United States of America & 4 & 11 & 7 & 2 & 6 & 2 \\
\hline Southeast Asia Region & 0 & 1 & 0 & 0 & 0 & 3 \\
\hline & & & & & & \\
\hline
\end{tabular}

\section{Recommendations for Improving Renewable Energy Resource Information in the APEC Region}

The information included in this paper indicates that an abundant supply of renewable energy resources is available throughout the APEC region, and that useful "first order" assessments of this potential energy resource have already been conducted for most technologies for virtually all APEC economies. However, many studies of renewable energy resources in the APEC region are limited by poor-quality data or lack of data altogether, and by limited use of more advanced techniques for estimating resources where there is no data. For example:

- Wind data is generally available only through national weather service offices, which are not necessarily located in the windiest regions of an economy. Many of the windier regions have no measurements available at all. Furthermore, there are occasions when the instruments used to collect the available data are subject to poor exposure because of 
nearby growth of vegetation or installation of buildings. In some instances, the instruments are not properly maintained or calibrated, which can result in degradation of the measurements over time.

- $\quad$ Much of the solar data is derived from an empirical formula, known as the Angstrom relation, applied to an extensive network of sunshine recorders throughout the region. These empirical relationships are subject to large errors, and are applied inconsistently throughout the region. Only on rare occasions were high-quality solar measurements identified using modern, calibrated equipment.

In addition, there is a wide disparity in the approach used to assess resources across the economies, and a lack of a centralized source of this information, which can make access to much of the information difficult. As a result, four major recommendations arise from this survey to improve the quality and completeness of renewable energy resource information in the APEC region:

1. Upgrade measurement systems: "Benchmark" solar and wind measurement sites should be established in representative regions within each economy using equipment that can be calibrated to international standards and that collects data in a format that specifically applies to renewaitle technologies, such as wind measurements on tall towers, to gather data at typical machine hub heights.

2. Use advanced wind and solar assessment techniques: Recently, models have been developed that can estimate wind and solar resources reliably where there are no actual measurements. These models, especially when coupled with data collected at the "benchmark" measurement stations, can greatly improve the assessment and reliability of the spatial distribution of solar and wind resources. For example, recent developments in satellite data analysis techniques can be applied to greatly improve the assessment of solar resources throughout the region.

3. Improve national biomass, geothermal, and hydro surveys: The literature review conducted for this study indicates that reliable national surveys of these three renewable energy resources can be limited or difficult to find. There may be some national survey information, particularly for hydro resources already in wide use in many economies, but it did not show up in the electronic library search. Development of and access to this survey information is needed throughout the APEC region; specifically, agreement as to how these surveys are conducted should be reached by all member economies, so that uniform and comparable surveys result.

4. Establish a centralized data center: Easy access to renewable resource information is critical if the use of these technologies is to be advanced. We recommend that a centralized data $\%$ nter be established by APEC that facilitates access to all published renewable energy data by all economies. As an example of such a data center, NREL has established an electronic renewable resource data center, available on the World Wide Web (http://redc.nrel.gov), that will eventually contain all relevant renewable resource data for the United States in a format that can be easily accessed by users logging in to the site. Such a centralized data source should be established by APEC for all member economies.

\section{References for this Section}

1. Elliot, D.L.; C.G. Holladay; W.R. Barchet; H.P. Foote; W.F. Sandusky. 1987. "Wind Energy Resource Atlas of the United States," DOE/CH10094-4, DE86004442 UC 
Category 60, Solar Technical Information Program, Solar Energy Research Institute (now NREL), Golden, CO, 80401, U.S.A.

2. NSRDB Volume 1, 1992: Users Manual: National Solar Radiation Data Base (1961 1990), Version 1.0. Prepared by the National Renewable Energy Laboratory, Golden, CO 80401, U.S.A.

3. Whitlcok, C.H., et al., 1993: WCRP Surface Radiation Budget Shortwave Data Product Description, Version 1.1. NASA Technical Memorandum 107747, NASA Langley Research Center, Hampton, Virginia 23681, U.S.A. Available on CD_ROM from the Langley DAAC User and Data Services Office, NASA Langley Research Center, Mail Stop 157B, Hampton, VA 23681-0001, U.S.A.

4. Real Time Nephanalysis Data Base. Available from the National Climatic Data Center, 151 Patton Ave., Asheville, NC, 28801-5001, U.S.A.

5. Maxwell, E.L.; R.L. George; E.H. Brady, 1996: Estimating Worldwide Solar Radiation Resources on a $40 \mathrm{~km}$ Grid. Proceedings of the 1996 Annual Conference, Asheville, North Carolina, U.S.A., 13-18 April. American Solar Energy Society, 2400 Central Avenue, Suite G-1, Boulder CO 80301, U.S.A., pp. 235-240.

6. University of Lowell Photovoltaic Program. 1991: International Solar Irradiation Database, Version 1.0. University of Lowell Research Foundation, Lowell MA 01854, U.S.A.

7. Tsvetkov, A.; S. Wilcox; D. Renné; M. Pulscak, 1995: International Solar Resource Data at the World Radiation Data Center. Proceedings of the 1995 Annual Conference, Minneapolis, Minnesota, U.S.A., 15-20 July, 1995, American Solar Energy Society, 2400 Central Avenue, Suite G-1, Boulder CO 80301, U.S.A., pp. 216-219. 


\section{Australia (AUS)}

\section{Overview of Australia's Energy Production}

Energy demand is growing in Australia at an annual rate of $2 \%$ (AUS-B1). Ninety percent of total electric energy is produced by thermal power plants, most of them coal-burning. A large coal-burning power plant (Loy Yang B) and a 2000-MW thermal power facility at the Latrobe surface mine (200 km from Melbourne) are under construction. The remaining $10 \%$ is supplied by hydroelectric power stations. Some $30 \%$ of generated electricity is consumed by the private sector (AUS-N1).

There is a 200-year reserve of economically recoverable resources of coal and a 40-year reserve of natural gas. Approximately $70 \%$ of Australian coal and $30 \%$ of natural gas is currently exported. Renewable sources of energy supply $6 \%$ of Australia's total energy needs. Most of this comes from large-scale hydro and biomass (AUS-N5).

\section{Wind Resources}

The development of Australian wind energy has been limited by a lack of knowledge of the available hub-height wind resource, and no national wind resource surveys were identified in this study. Conventional wind monitoring at places such as airport stations generally underestimate the wind speeds at typical wind turbine hub height. To correct for this problem, the WA $\mathrm{S}$ model, a numerical method for extrapolating site-specific wind data, developed by Riso national Laboratory in Denmark, has been applied to specific areas in Australia (AUS-W 1). For example, the wind energy potential in the Swan coastal plain of Western Australia is dominated by the sea breeze circulation and topographic influence. Sea breezes are common in the June, July, and August climate, but only under otherwise weak synoptic flows can they be a significant source of energy. However, mesoscale topographic effects are significant under all synoptic conditions (AUS-W3).

To measure wind energy in the non-coastal area of Sydney, a location at Lindfield, Sydney's northern suburb, was selected (AUS-W4). A Gill four-bladed helicoidal propeller anemometer bivane was mounted at $10 \mathrm{~m}$ height. The data collection period ran from December 1982 to August 1985. The following table provides summarized wind velocities at this location:

\begin{tabular}{|l|c|}
\hline \multicolumn{1}{|c|}{ Season } & Mean Velocity \\
\hline \hline June, July, August & $2.6 \mathrm{~ms}^{-1}$ \\
\hline September, October, November & $1.6 \mathrm{~ms}^{-1}$ \\
\hline December, January, February & $1.4 \mathrm{~ms}^{-1}$ \\
\hline March, April, May & $2.2 \mathrm{~ms}^{-1}$ \\
\hline
\end{tabular}

The observed wind speeds were lower at night and highest from November to March. These speeds were much lower than $6 \mathrm{~ms}^{-1}$, which is considered a minimum hub-height wind speed for 
wind energy production. Thus, it was concluded that this non-coastal area of Sydney is not suitable for wind energy use.

\section{Solar Resources}

About $4 \%$ of households in Australia rely on solar energy to supply many of their hot water needs. In rural areas, solar power supply systems are being used to meet the electricity needs of thousands of telecommunication installations, water pumps, and isolated houses (AUS-N5).

The Australian network for monitoring global solar radiation consists of 22 stations (13 of which have the capability to measure diffuse). In 1992 this network consisted of different types of systems, all of which are now considered obsolete (AUS-S1). Quality control required manual input, which contributed to substantial costs in operating the network. The network is now undergoing renovation. Plans include:

- $\quad$ Replacing the current instruments with more modern equipment

- Quality control

- Increasing interpretation capability.

Estimates of monthly mean values of daily total solar radiation in Australia from sunshine records have been made using the Angstrom formula (AUS-S2):

$$
\mathrm{H} / \mathrm{H}_{\mathrm{O}}=\mathrm{a}+\mathrm{bn} / \mathrm{N}
$$

where:

$\mathrm{H}$ is the total radiation received at earth's surface

$\mathrm{H}_{\mathrm{O}}$ is the radiation received on a horizontal surface at the top of atmosphere

$\mathrm{n}$ is the measured total duration of sunshine (in hours)

$\mathrm{N}$ is the maximum possible number of sunshine hours

$\mathrm{a}, \mathrm{b}$ are regression coefficients

The $\mathrm{a}$ and $\mathrm{b}$ values were derived by Haunam (AUS-S2) from 458 monthly observations obtained at six Australian stations, ranging from 3 to 10 years. Thus, for this study, (1) becomes:

$$
\mathrm{H} / \mathrm{H}_{\mathrm{o}}=0.26+0.50 \mathrm{n} / \mathrm{N}
$$

Haunam then used this equation to calculate the total the total surface radiation for stations equipped with Campbell-Stokes sunshine recorders. Nix and Kalma have applied Haunam's formula to estimate total annual solar radiation for 33 stations in Northern Australia stations and Papua New Guinea (AUS-S2).

For Australia, between $20^{\circ}$ and $43^{\circ} \mathrm{S}$ latitudes, Spencer (IN-S1) developed a model for estimating the diffuse fraction of global radiation, correlating hourly diffuse radiation $\left(\mathrm{H}_{d} / \mathrm{H}\right)$ with hourly clearness index $\mathrm{K}_{\mathrm{T}}$ :

$$
\begin{aligned}
& \mathrm{H}_{\mathrm{d}} / \mathrm{H}=0.585+0.00775 \mathrm{LAT}\left(\text { for } 0<\mathrm{K}_{\mathrm{T}}<0.35\right) \\
& \left.\mathrm{H}_{\mathrm{d}} / \mathrm{H}=0.94+0.0118 \mathrm{LAT}-(1.185+0.0135 \mathrm{LAT}) \mathrm{K}_{\mathrm{T}} \text { for } 0.35<\mathrm{K}_{\mathrm{T}}<0.75\right) \\
& \mathrm{H}_{\mathrm{d}} / \mathrm{H}=0.0513-0.00167 \mathrm{LAT}\left(\text { for } \mathrm{K}_{\mathrm{T}}>0.75\right)
\end{aligned}
$$


where:

LAT is the modulus of latitude, degrees,

$\mathrm{H}$ is the hourly total radiation on a horizontal surface,

$\mathrm{H}_{\mathrm{d}}$ is the hourly diffuse radiation incident on a horizontal surface

Overall, Australian solar energy resources are considered favorable. In Darwin, for example, only $8 \%$ of the days have less than $4.17 \mathrm{kWh} / \mathrm{m}^{2}$ irradiation; $25 \%$ of the days have irradiation greater than $6.95 \mathrm{kWh} / \mathrm{m}^{2}$. Even during the monsoon season, which lasts from December to March, more than $30 \%$ of the days have irradiation greater than $6.95 \mathrm{kWh} / \mathrm{m}^{2}$ (INA-S1).

Uncertainties in measured solar radiation data are as follows (AUS-S5):

Direct Solar: $3 \%$ or $10 \mathrm{Wm}^{2}$

Diffuse Solar: $4 \%$ or $5 \mathrm{Wm}^{2}$

Global Solar (derived): $4 \%$ or $15 \mathrm{Wm}^{2}$

The three locations with the highest yearly average global horizontal solar irradiation are (SE-S1):

\begin{tabular}{|l|c|}
\hline \multicolumn{1}{|c|}{ Location } & Yearly Average Radiation \\
\hline \hline Kajabbi & $6.15 \mathrm{kWhm}^{2}{ }^{2}$ day- $^{1}$ \\
\hline Port Headland & $6.14 \mathrm{kWhm}^{-2}{ }^{2}$ day- $^{1}$ \\
\hline Broome & $6.98 \mathrm{kWhm-}{ }^{2}$ day- $^{1}$ \\
\hline
\end{tabular}

The table on the following page shows other locations throughout Australia, showing values calculated for a Typical Meteorological Year (TMY) and the long-term average (AU-S4):

\section{Biomass Resources}

The most promising biomass-based energy systems in Australia are:

- $\quad$ Liquid fuels from food-processing wastes and lignocellulose,

- $\quad$ Heat and electricity production from a number of waste streams, including municipal solid waste and other forms of waste (AUS-B2).

Bagasse from sugar cane is used as source of heat and electricity at sugar mills and supplies $2 \%$ of the economy's primary energy. Furthermore, biomass could be used to meet one-third of Australia's current demand for oil and supply 5\% of the electricity (AUS-N5). Biomass can be converted to both energy and to ethanol, which can be used as a transportation fuel (AUS-B1). 


\begin{tabular}{|c|c|c|c|c|}
\hline \multirow[b]{2}{*}{ Location } & \multicolumn{2}{|c|}{ TMY } & \multicolumn{2}{|c|}{ Average } \\
\hline & $\mathrm{MJ} / \mathrm{m}$ & $\mathrm{kWh} / \mathrm{m}^{2}$ & $\mathrm{MJ} / \mathrm{m}$ & $\mathrm{kWh} / \mathrm{m}^{2}$ \\
\hline Hobart & 13.5 & 3.75 & 13.7 & 3.80 \\
\hline Rockhampton & 19.0 & 5.28 & 19.0 & 5.28 \\
\hline Melbourne & 14.5 & 4.03 & 14.6 & 4.05 \\
\hline Perth & 18.8 & 5.22 & 18.3 & 5.08 \\
\hline Alice Springs & 21.9 & 6.08 & 22.2 & 6.17 \\
\hline Sydney & 16.7 & 4.64 & 16.9 & 4.69 \\
\hline Mildura & 18.5 & 5.14 & 18.6 & 5.18 \\
\hline Wagga Wagga & 17.8 & 4.95 & 17.9 & 4.97 \\
\hline Oodnadatta & 21.3 & 5.92 & 21.3 & 5.92 \\
\hline Mt. Gambier & 15.3 & 4.25 & 14.9 & 3.88 \\
\hline Darwin & 21.7 & 6.03 & 21.7 & 6.03 \\
\hline Albany & 15.7 & 4.36 & 15.5 & 4.31 \\
\hline Williamtown & 17.4 & 4.84 & 17.4 & 4.84 \\
\hline Laverton & 15.5 & 4.30 & 15.3 & 4.17 \\
\hline Geraldton & 21.2 & 5.89 & 20.9 & 5.81 \\
\hline Forrest & 20.0 & 5.56 & 20.0 & 5.56 \\
\hline Halls Creek & 22.3 & 6.19 & 22.3 & 6.19 \\
\hline Longreach & 21.8 & 6.06 & 22.0 & 6.11 \\
\hline Canberra & 17.6 & 4.89 & 17.4 & 4.84 \\
\hline Brisbane & 17.8 & 4.95 & 17.5 & 4.86 \\
\hline Adelaide & 18.3 & 5.08 & 17.8 & 4.95 \\
\hline
\end{tabular}

\section{Geothermal Resources}

Natural geothermal hot springs and hot artesian bores have already been developed for recreational and therapeutic purposes in Australia. A district heating system at Portland, Otway Basin of Western Victoria, has proved reliable, servicing $18,990 \mathrm{~m}^{2}$ of building area. There are plans to expand its capacity for manufacturing uses. A geothermal well provides hot water for 
Traralgon's (Gippsland Basin of Eastern Victoria) paper manufacture. There is a 4-year production trial from water aquifers going on at Birdsville, Queensland (AUS-G1).

Hot dry rock (HDR) geothermal energy is a clean, feasible option for Australia. This resource is abundant because of the thermal blanketing effect of sedimentary basins and plenty of heat-producing basement rocks. Because of the favorable reservoir horizontal and sub-horizontal orientation with minimum leakage of water, and ease of drilling through sedimentary basins to the basement, which allows to keep the costs low, it can be exploited efficiently. Since, like fossil fuels, it is based upon geotechnology, conversion could be made without disrupting the present industry. HDR reservoirs are likely to be found in central Australia; there is a confirmed important location at Cooper Basin. Thus, these locations are convenient for remote power generation. An experimental facility is proposed to be built in Sydney Basin near Muswellbrook (AUS-G1, AUS-G2).

\section{Hydro Resources}

No general discussion on the country-wide hydro resources was identified in the literature. However, the Ord River in Western Australia has considerable hydro potential (AUS-H2). More than 10 attempts by various organizations to install a commercially viable hydropower station failed. Finally, Halcrow Water Power Ltd. developed a \$75 million, 30-MW hydro scheme in Kanunurra at the foot of Lake Argyle, for which the company was recognized with the 1996 Engineering Excellence Award. The construction of a partially submerged in-water power station took 18 months. 
Table of References for Australia (see key following table for abbreviation and resource codes):

\begin{tabular}{|c|c|c|c|c|c|c|}
\hline Type of Analysis & Wind & Solar & Biomass & Geothermal & Hydro & General \\
\hline Site-Specific Analysis & $\begin{array}{l}\text { AUS-W3 } \\
\text { AUS-W4 }\end{array}$ & & & AUS-G1 & AUS-H2 & \\
\hline $\begin{array}{l}\text { Country-Wide } \\
\text { Surveys }\end{array}$ & & & & & & \\
\hline Country-Wide Maps & & AUS-S2 & & & & \\
\hline $\begin{array}{l}\text { Modeled Data } \\
\text { Sources }\end{array}$ & & $\begin{array}{l}\text { AUS-S2 } \\
\text { INA-S1 }\end{array}$ & & & & \\
\hline $\begin{array}{l}\text { Measured Data } \\
\text { Sources }\end{array}$ & AUS-W4 & $\begin{array}{l}\text { AUS-S2 } \\
\text { AUS-S4 } \\
\text { AUS-S5 } \\
\text { INA-S1 } \\
\text { SE-S1 }\end{array}$ & & & & $\begin{array}{l}\text { AUS-N1 } \\
\text { AUS-N5 }\end{array}$ \\
\hline $\begin{array}{l}\text { Technology or } \\
\text { Economic } \\
\text { Assessment Only }\end{array}$ & AUS-W1 & $\begin{array}{l}\text { AUS-S1 } \\
\text { AUS-N5 }\end{array}$ & $\begin{array}{l}\text { AUS-B1 } \\
\text { AUS-B2 }\end{array}$ & AUS-G2 & & \\
\hline
\end{tabular}

Key:

Abbreviations

Australia $=$ AUS

Indonesia $=$ INA

South East Asia Region = SE

\section{$\underline{\text { Resources }}$}

Wind $=\mathrm{W}$

Solar $=$ S

Biomass $=\mathrm{B}$

Geothermal $=\mathrm{G}$

Hydro $=\mathrm{H}$

General $=$ N 


\section{Brunei Darussalam (BD)}

\section{Overview of Brunei Darussalam's Energy Production}

This member economy is located on the Island of Borneo. Brunei covers an area $5,765 \mathrm{~km}^{2}$ (BD-N1). Of this total, $79 \%$ is forest and woodland. Permanent crops, arable land, meadows, and pastures take up approximately $1 \%$ each; the remaining $18 \%$ is allocated to other uses (BD-N2). Rice paddy and cassava manioc are Brunei's principal crops, each yielding 1,000 tonnes in 1994. Total roundwood removal in 1995 amounted to 389,800 metric tons. Brunei excels in fossil fuel production as the following table shows (BD-N1):

\begin{tabular}{|l|c|c|}
\hline \multicolumn{1}{|c|}{ Type of Fuel } & Amount & Year \\
\hline \hline Crude petroleum & $8,900,000$ tonne & 1995 \\
\hline Natural gasoline & 47,000 tonnes & 1993 \\
\hline Natural gas & 11,185 million $\mathrm{m}^{3}$ & 1995 \\
\hline
\end{tabular}

Petroleum production peaked at 240,000 barrels a day in 1979 , then leveled out to 140,000 barrels a day by the late 1980s. Almost all natural gas is liquefied and exported to Japan. Brunei is the world's fourth largest exporter of liquefied natural gass (LNG). In 1989 natural gas production was about $877,000 \mathrm{ft}^{3} /$ day. A small amount of it is used for domestic power generation. At current production rates, oil reserves are sufficient for at least the next 20 years; natural gas for more than 30 years (BD-N4).

Brunei has the second highest (after Singapore) energy consumption per capita in the Asean region. The following table shows Brunei's energy consumption levels compared with a few of its Asean neighbors (SE-N3):

\begin{tabular}{|l|c|}
\hline \multicolumn{1}{|c|}{ Country } & $\begin{array}{c}\text { Energy Consumption per capita (tons } \\
\text { of oil equivalent (toe)) }\end{array}$ \\
\hline \hline Brunei & 3.80 \\
\hline Indonesia & 0.23 \\
\hline Malaysia & 0.78 \\
\hline Philippines & 0.38 \\
\hline Singapore & 4.46 \\
\hline Thailand & 0.33 \\
\hline
\end{tabular}


The climate is tropical-hot, humid, and rainy (BD-N2). Coastal rainfall totals up to $254 \mathrm{~cm}$ annually and in the interior, annual rainfall totals of $508 \mathrm{~cm}$ are recorded. Average daily temperatures range from $24^{\circ} \mathrm{C}$ to $30^{\circ} \mathrm{C}$, with extremes ranging from $20^{\circ} \mathrm{C}$ to $35^{\circ} \mathrm{C}(\mathrm{BD}-\mathrm{N} 3)$.

Two stations, Anduki and Seria, took weather measurements for 12 years. The average annual temperature at Anduki was $27.5^{\circ} \mathrm{C}$; the temperature for the Seria station was not available (BD-S3).

\section{Wind Resources}

The yearly average wind velocity in neighboring Malaysia ranges from $3.6 \mathrm{~m} / \mathrm{s}$ to $5.6 \mathrm{~m} / \mathrm{s}$, so it can be inferred that Brunei's conditions are similar to Malaysia (SE-N1).

\section{Solar Resources}

Information from neighboring Malaysia is used to assess solar resources for this member economy. Most available solar radiation estimates for Malaysia use an Angstrom-type regression equation such as shown in equation (1) under Australia.

The most significant problem with equation (1) is that the regression coefficients a and b vary depending on the amount of rainfall (MAS-S4). Malaysia's solar radiation in June ranges from 4.64 to $5.22 \mathrm{kWh} / \mathrm{m}^{2}$ day, and in December from 4.06 to $4.64 \mathrm{kWh} / \mathrm{m}^{2}$ (SE-N1). Given Brunei's proximity to Malaysia, it can be inferred that Brunei's conditions are similar.

To estimate monthly average daily diffuse solar radiation, the two universal methods of Iqbal and Gopinathan can be applied. Data was obtained for a 5-year period. Iqbal's method as applied to Brunei/ Muara resulted in the relation:

where:

$$
\mathrm{H}_{\mathrm{d}} / \mathrm{H}_{\mathrm{o}}=-0.263+1.592\left(\mathrm{~S} / \mathrm{S}_{\mathrm{o}}\right)-1.216(\mathrm{n} / \mathrm{N})
$$

$\mathrm{H}_{\mathrm{d}}=$ monthly average daily diffuse radiation

$\mathrm{H}_{\mathrm{O}}=$ extraterrestrial radiation on horizontal surface

$\mathrm{n}=$ average daily value of bright sunshine

$\mathrm{N}=$ maximum possible sunshine hours (day-length)

The Gopinathan correlation takes into account the clearness index $\mathrm{K}_{\mathrm{T}}$, so for Brunei/ Muara:

where:

$$
\mathrm{H}_{\mathrm{d}} / \mathrm{H}=1 / 752-4.223 \mathrm{~K}_{\mathrm{T}}+1.532(\mathrm{n} / \mathrm{N})
$$

$$
\begin{aligned}
& \mathrm{K}_{\mathrm{T}}=\mathrm{H} / \mathrm{H}_{\mathrm{O}}, \\
& \mathrm{H}=\text { global solar radiation } \\
& \mathrm{H}_{\mathrm{d}}=\text { monthly average daily diffuse radiation, } \\
& \mathrm{H}_{\mathrm{O}}=\text { extraterrestrial radiation on horizontal surface, } \\
& \mathrm{n}=\text { average daily value of bright sunshine, } \\
& \mathrm{N}=\text { maximum possible sunshine hours (day-length) }
\end{aligned}
$$

Equation (7) is somewhat more accurate than equation (6), as it yields a smaller root-mean-square error. The estimated values of diffuse radiation are approximately the same for four stations in Brunei because the difference in latitude is less than $1^{\circ}$ (BD-S1). 
Table of References for Brunei Darussalam (see key following table for abbreviation and resource codes):

\begin{tabular}{|l|c|c|c|c|c|c|}
\hline \multicolumn{1}{|c|}{ Type of Analysis } & Wind & Solar & Biomass & Geothermal & Hydro & General \\
\hline \hline $\begin{array}{l}\text { Site-Specific } \\
\text { Analysis }\end{array}$ & & & & & & \\
\hline $\begin{array}{l}\text { Country-Wide } \\
\text { Surveys }\end{array}$ & & & & & & $\begin{array}{c}\text { BD-N1 } \\
\text { BD-N3 }\end{array}$ \\
\hline $\begin{array}{l}\text { Country-Wide } \\
\text { Maps }\end{array}$ & & & & & & BD-N3 \\
\hline $\begin{array}{l}\text { Modeled Data } \\
\text { Sources }\end{array}$ & & BD-S1 & & & & \\
\hline $\begin{array}{l}\text { Measured Data } \\
\text { Sources }\end{array}$ & SE-N1 & BD-S1 & & & & BD-N1 \\
& & SE-N1 & & & & BD-N2 \\
& & & & & & BD-N3 \\
& & & & & BD-S3 \\
Sechnology or & BD-S2 & & & & & \\
$\begin{array}{l}\text { Economic } \\
\text { Assessment Only }\end{array}$ & & & & & & \\
\hline
\end{tabular}

Key:

$\underline{\text { Abbreviations }}$

Brunei $=\mathrm{BD}$

South East Asia Region $=$ SE

Malaysia $=$ MAS $\underline{\text { Resources }}$

Wind $=\mathrm{W}$

Solar $=\mathrm{S}$

Biomass $=\mathrm{B}$

Geothermal = G

Hydro $=\mathrm{H}$

General $=\mathrm{N}$ 


\section{Canada (CDA)}

\section{Overview of Canada'sEnergy Production}

In 1994, the primary energy supply of Canada, 9,918 peta-joules (PJ) was derived from the following resources:

- $\quad$ Refined petroleum products: $33 \%$

- Natural gas: $26 \%$

- $\quad$ Renewables (including hydro): $17 \%$

- Nuclear power: $11 \%$

- Coal: $10 \%$

- $\quad$ Liquefied petroleum products: $3 \%$

As can be seen from this list, the share of renewables is fairly large (CDA-N5). This category consists of large-scale hydroelectricity $(1,145 \mathrm{PJ}$, or $60 \%)$, small-scale hydroelectricity (28 PJ), industrial biomass (456 PJ), and residential biomass (100 PJ).

At present, up to 2,000 MW of small hydro capacity are installed (plus, another 9,000 MW have been identified) and 1,400 MW of biomass are planned to be developed by the year 2010 (CDA-N5, CDA-N3). By then, most renewable energy technologies, except PV, are expected to be cost competitive. If a $\$ 0.02 / \mathrm{kWh}$ social/environmental premium is included in estimations, the renewable capacity that can be expected to be installed increases from 4,600 MW to more than 16,500 MW (CDA-N3).

\section{Wind Energy Resources}

Using current wind turbine technology, electricity in Canada can be generated from wind at costs that can compete with thermal power stations. For example, a wind farm consisting of 100 bonus 450-kW turbines at Cape Race can produce more than $94,670 \mathrm{MW}$ annually at a cost of \$0.0572/ $\mathrm{kWh}$. The energy potential at Cape Race appears to be the highest at 40,267 MWh/yr, followed by Battle Harbour at 38,871 MWh/yr and Twillingate at 35,525 MWh/yr (CDA-W1). The following table demonstrates a potential electrical output from a bonus $450 \mathrm{~kW}$ at various wind speeds at Cape Race (CDA-W1):

\begin{tabular}{|l|c|c|c|c|c|c|c|c|}
\hline Speed $(\mathrm{m} / \mathrm{s})$ & 4 & 5 & 6 & 7 & 8 & 9 & 10 & 11 \\
\hline MWh produced & 7.2 & 24.9 & 158.7 & 253.2 & 192.9 & 221.1 & 109.2 & 29.4 \\
\hline
\end{tabular}

In Quebec, a 100-MW wind energy power plant is planned; in Ontario $125 \mathrm{MW}$ of renewable electricity has been added to the grid. Current installed capacity of wind power plants is about 23 $\mathrm{MW}$, most of it concentrated in Alberta. Another $130 \mathrm{MW}$ are planned during the next 2 years in Ontario and Quebec (CDA-N5). 


\section{Solar Resources}

The Atmospheric Environmental Service (AES) of Canada measured solar radiation incident on a horizontal surface on an hourly basis for 50 sites and archived this data between 1967 and 1976 (CDA-S2). To estimate solar radiation and its components (diffuse, direct beam, and ground reflected) on horizontal and tilted surfaces, AES has implemented computer simulation models for 129 sites. The models used were:

- $\quad$ MAC3 (uses hourly archived meteorological elements as an input)

- WON (uses hourly total cloud opacity and global solar radiation (RF1) and diffuse (RF2) if available)

- Interpolation (uses linear interpolation to fill gaps of up to 2 hours if the data is missing)

- $\quad$ HAY (for tilted surfaces, uses hourly values of albedo and sky diffuse and direct solar radiation on a horizontal surface as an input).

A study conducted in 1992 found that the Perez method for modeling solar irradiance outperforms the MAC3 and WON models (CDA-S7).

The following table shows solar radiation measurements from four stations throughout Canada for 9 years (CDA-S6):

\begin{tabular}{|l|c|c|c|c|}
\hline \multirow{4}{*}{ Station Location } & \multicolumn{3}{|c|}{ Mean Measured Radiation $\left(\mathrm{kWh} / \mathrm{m}^{2}\right)$} \\
\cline { 2 - 5 } & Hourly & Daily & Hourly & Daily \\
\hline \hline Charlottetown & 0.288 & 3.462 & -- & -- \\
\hline Goose Bay & 0.242 & 2.873 & 0.149 & 1.512 \\
\hline Toronto & 0.207 & 3.665 & 0.144 & 1.698 \\
\hline Winnipeg & 0.305 & 3.655 & -- & -- \\
\hline
\end{tabular}

The highest yearly averaged global horizontal irradiation is observed at the following locations (SE-S1):

\begin{tabular}{|l|r|}
\hline \multicolumn{1}{|c|}{ Location } & Yearly Average Radiation \\
\hline \hline Lethbridge & $4.03 \mathrm{kWhm}-{ }^{2}$ day- ${ }^{1}$ \\
\hline Suffield & $3.94 \mathrm{kWhm}^{2}{ }^{2}$ day- ${ }^{1}$ \\
\hline Winnipeg & $3.85 \mathrm{kWhm-}-{ }^{2}$ day- ${ }^{1}$ \\
\hline
\end{tabular}


The world's largest solar collector, with a total area of $10,000 \mathrm{~m}^{2}$, has been installed near Montreal. Overall, 20,000 PV systems are installed in Canada, with a generating capacity of 1.5 to $3.0 \mathrm{MW}$, which is growing at $30 \%$ annually (CDA-N5).

The Canadian Weather Energy and Engineering Data Sets (CWEEDS) include measurements of solar global horizontal irradiance from 35 of 143 CWEEDS stations. Direct normal irradiance is estimated from global horizontal irradiance. Diffuse horizontal irradiance is measured at five locations (CDA-S3, CDA-S7). This database shows that the maximum daily solar radiation on a horizontal surface generally occurs in July. For a south-facing surface, as the tilt level increases, the monthly distributions become bimodal, and the maxima move from early June, July, April, to March, April, May, and September, October, November. For the south-facing vertical surface, the maxima occur in February and October, with the February maxima being higher due to less cloudiness and more frequent snow cover, resulting in higher mean surface albedo (reflection). The annual incident solar radiation is maximized on the south-facing surface. For each surface orientation, the maximum solar radiation amount occurs in the southern prairies during January. The location of the maximum moves northward in late December, January, and February and early March, April, and May through Manitoba and Northwestern Ontario, then, through the Keewatin district of the northwest Territories to the high Arctic islands in May. By August, the maximum is once again in the southern prairies. The seasonal minima occur on leeward shores of large bodies of water, such as shores of the Great Lakes and west coast of Newfoundland, where cold Arctic winds sweep over the open water (CDA-S2).

In 1983, aerosols in the atmosphere (which formed as a result of 1982 El Chichon eruption in Mexico), caused strong reduction in direct beam and diffuse radiation (CDA-N3). The effects of this eruption were investigated in detail by John Garrison in 1994. The study focused on the period between 1965 and 1984 and included data from stations in Edmonton, Montreal, Port Hardy, Toronto, and Winnipeg. The results show that in 1984 there was still an excess amount of volcanic aerosols in the atmosphere. Sulfur dioxide $\left(\mathrm{SO}_{2}\right)$, formed as a result of volcanic eruption, is converted to sulfuric acid-water aerosols in the stratosphere. These acids tend to scatter solar radiation, which changes some of the direct radiation into diffuse radiation. Thus, direct beam radiation and collection by highly concentrating tracking collectors are significantly reduced (CDA-S9).

\section{Biomass Resources}

The biomass resource potential is such that some $25 \%$ of the economy's sustainable energy requirement can come from Canadian forests. Currently, biomass provides $5 \%$ of Canada's energy, largely generated from pulp and paper and related forest product industries. MSW accounts for 100-150 PJ, but only a few municipalities employ combustion techniques in energy-from-waste plants (CDA-N5).

Lignocellulosic materials are abundant, low-cost renewable biomass resources that can be converted to a variety of fuels and chemicals. A part of the mandate of the Alternative Energy Division of Energy Mines and Resources Canada is to fund research that targets the development and commercialization of conversion process (CDA-B2, CDA-B3).

\section{Hydro Resources}

Canada has substantial hydro resource potential (CDA-H3). The costs of routine operations and maintenance are stable and the overall cost of generating hydropower is low (CDA-H1). 


\section{Geothermal Resources}

Groundwater can be used a source of heat energy. Even though ground source heat pumps require a fairly high initial investment compared to air source systems, they have much higher energy efficiency. This technology is becoming more widespread in Canada. For example, Carleton University in Ottawa uses it for building heat. The city of Moose Jaw is developing a similar system for a public swimming pool and recreational facility (CDA-H4).

\section{Renewable Energy Resources for Specific Provinces}

Alberta

Alberta has abundant wind resource; baseline long-term average wind speed at $30 \mathrm{~m}$ height is about $6 \mathrm{~m} / \mathrm{s}$ and power density is about $400 \mathrm{~W} / \mathrm{m}$ (CDA-W2). The first Canadian wind energy power plant was built here (CDA-N5).

\section{British Columbia (BC)}

From 1978 to 1983, demonstrations and research projects that dealt with renewable energy were sponsored, but between 1983 and 1989, there was little provincial governmental activity with respect to renewable energy. Since 1989 there has been an interest in developing geothermal and small hydro resources. However, as of 1993, no detailed programs or policies have been put in place to promote renewables. Hydroelectric power supplies $85 \%$ of the province's total electrical needs. Solar energy is used in niche markets (CDA-N1). Wind power is successfully used in dozens of small cities (CDA-N1).

The British Columbia coast shows minimum incident solar radiation amounts for any surface orientation during every month because of cloudiness, which is common for coastlines (CDA-S2).

There are 15 volcanic centers and 60 hot springs available for exploiting geothermal energy. Most high-grade geothermal prospects in British Columbia are located along three volcanic belts in the southwestern region of the province. More than $800 \mathrm{MWe}$ can be generated from several known prospects. There are significant low-grade geothermal resources in several provincial regions. Market uses for geothermal energy include electrical generation, other direct heat uses, and recreation (CDA-G2).

The recent Resource-Smart program aims to obtain additional hydroelectric energy from generation, transmission, and distribution facilities, and for expanding the generation capability at Aberfeldie station, a 5-MW plant in southeastern British Columbia. The program is cost-effective, and envisions an additional 25-MW capacity powerhouse to be built (CDA-G1, CDA-H2). Furthermore, plans for hydropower for this decade include upgrade and rehabilitation work, stabilizing the routine operation costs, and keeping the overall hydropower generating costs low (CDA-H1). 


\section{Saskatchewan}

Coal-fired electricity-generation stations produce $70-75 \%$ of the province's power requirements, yet Saskatchewan has more than 1,200 MW of wind-generated electricity potential.

Saskatchewan has the highest availability of solar radiation resources in Canada. The average solar radiation on a horizontal surface is approximately $3.89 \mathrm{kWh} / \mathrm{m}^{2}$ per day in the southern part of the province. On a monthly basis, the solar radiation varies from $1.11 \mathrm{kWh} / \mathrm{m}^{2}$ per day in December, January, and February to $6.67 \mathrm{kWh} / \mathrm{m}^{2}$ per day in June, July, and August. By tilting the collector surface to an angle approximately equal to latitude, solar radiation values over the year are more even with annual values, ranging from $3.22 \mathrm{kWhm}^{-} \mathrm{day}_{-}{ }^{1}$ to $5.95 \mathrm{kWhm}-{ }^{2} \mathrm{day}-{ }^{1}$. A tilted collector, thus, maximizes the year-round supply of radiation.

Solar water heaters are competitive in Saskatchewan. They are used to heat residential swimming pools and provide domestic hot water during June, July, and August. In December, January, and February, when the demand for electricity peaks, the PV systems' capability is quite limited, but they perform much better in June, July, and August. Unfortunately, no solar technology is currently being manufactured in Saskatchewan. But many distributors of PV systems serve mainly the off-grid water-pumping and other markets.

Sustainable production rates for crop residues and forages, sources of biomass power, have been estimated at about 4,500,000 tonnes/yr. Rates for waste wood, logging residues, and fire kill are about 10,135,000 tonnes/yr. For municipal solid waste the rates are only 150,000 tonnes/yr.

The "best case" scenario for Saskatchewan's geothermal resources is using its low-grade geothermal potential for warming water used for heating buildings. However, it is expensive because of required deep drilling.

Hydro resources are used on a relatively large scale in Saskatchewan. There are seven hydroelectric plants with rated capacity of $847 \mathrm{MW}$, which is $30 \%$ of Sask Power's total electricity generation capacity. The remaining undeveloped capacity is estimated at 1,700 MW. This potential is distributed as follows:

- $\quad$ Saskatchewan River, $950 \mathrm{MW}$

- Churchill River, 450 MW

- Lake Athabosca drainage area, $300 \mathrm{MW}$.

A survey of potential small-head hydro sites in Saskatchewan has identified $150 \mathrm{MW}$ of potential capacity that can be developed in a cost-competitive way. The facilities can range from 1 to 50 MW at the Churchill and Fond-du-Lac river systems.

\section{Nova Scotia, Springhill}

Many abandoned mines have been successfully used to produce geothermal energy (CDA-G1). A demonstration of a geothermal heating system is under evaluation (CDA-H4). 
Table of References for Canada (see key following table for abbreviation and resource codes):

\begin{tabular}{|c|c|c|c|c|c|c|}
\hline Type of Analysis & Wind & Solar & Biomass & Geothermal & Hydro & General \\
\hline $\begin{array}{l}\text { Site-Specific } \\
\text { Analysis }\end{array}$ & $\begin{array}{l}\text { CDA-W2 } \\
\text { CDA-W1 } \\
\text { CDA-N6 }\end{array}$ & $\begin{array}{l}\text { CDA-S4 } \\
\text { CDA-N6 }\end{array}$ & CDA-N6 & $\begin{array}{l}\text { CDA-G1 } \\
\text { CDA-G2 } \\
\text { CDA-N6 } \\
\text { CDA-H4 }\end{array}$ & $\begin{array}{l}\text { CDA-N1 } \\
\text { CDA-N6 }\end{array}$ & $\begin{array}{l}\text { CDA-N1 } \\
\text { CDA-N6 }\end{array}$ \\
\hline $\begin{array}{l}\text { Country-Wide } \\
\text { Surveys }\end{array}$ & & & & & & $\begin{array}{l}\text { CDA-S9 } \\
\text { CDA-N3 }\end{array}$ \\
\hline Country-Wide Maps & & $\begin{array}{l}\text { CDA-S2 } \\
\text { CDA-S6 } \\
\text { CDA-S8 }\end{array}$ & & & & \\
\hline $\begin{array}{l}\text { Modeled Data } \\
\text { Sources }\end{array}$ & CDA-W1 & $\begin{array}{l}\text { CDA-S2 } \\
\text { CDA-S6 } \\
\text { CDA-S7 }\end{array}$ & & & & \\
\hline $\begin{array}{l}\text { Measured Data } \\
\text { Sources }\end{array}$ & $\begin{array}{l}\text { CDA-N6 } \\
\text { CDA-N7 }\end{array}$ & $\begin{array}{c}\text { CDA-S1 } \\
\text { CDA-S2 } \\
\text { CDA-S3 } \\
\text { CDA-S5 } \\
\text { CDA-S6 } \\
\text { CDA-S9 } \\
\text { CDA-N6 } \\
\text { CDA-N7 } \\
\text { SE-S1 }\end{array}$ & CDA-N6 & CDA-N6 & CDA-N6 & $\begin{array}{r}\text { CDA-N3 } \\
\text { CDA-N6 }\end{array}$ \\
\hline $\begin{array}{l}\text { Technology or } \\
\text { Economic } \\
\text { Assessment Only }\end{array}$ & & & $\begin{array}{l}\text { CDA-B2 } \\
\text { CDA-B3 } \\
\text { CDA-N5 }\end{array}$ & CDA-H4 & $\begin{array}{l}\text { CDA-H1 } \\
\text { CDA-H3 } \\
\text { CDA-N3 } \\
\text { CDA-N5 } \\
\text { CDA-H2 }\end{array}$ & \\
\hline
\end{tabular}

Key:

Resources

Abbreviations

Wind $=\mathrm{W}$

Canada $=\mathrm{CDA}$

South East Asia Region $=$ SE

Solar $=S$

Biomass $=\mathrm{B}$

Geothermal $=\mathrm{G}$

Hydro $=\mathrm{H}$

General $=$ N 


\section{Chile (CHL)}

\section{Wind Resources}

The largest area of high wind energy potential in South America is in southern argentina and Chile (CHL-W1). The same geographical features and climatological phenomena that power California's wind farms exist in the northern third of Chile. Southern Chile is considered one of the windiest regions in the world. Wind power has been used in Chile for a long time to supply small remote loads such as pipeline instrumentation and microwave repeaters. Locations in mainland Chile, such as Punta Arenas and Balmaceda, have mean wind speeds of 7-9 m/s (CHLW4) (anemometer height was not specified, but assumed to be $10 \mathrm{~m}$ ), high enough for large power generation. Punta Arenas is the largest city with high wind speeds, but cheap natural gas impedes the commercialization of wind power generation. Island sites at Diego Ramirez and Islates Faro have yet higher wind speeds, averaging $8.7 \mathrm{~m} / \mathrm{s}$ and $9.3 \mathrm{~m} / \mathrm{s}$, respectively. Three sites near Calama, elevation $2400-3000 \mathrm{~m}$, have speeds of $7-8 \mathrm{~m} / \mathrm{s}$ and a consistent diurnal pattern. Wind speeds peak at 3:00 p.m. The following table shows these sites and a few others separately (CHL-W4):

\begin{tabular}{|l|c|c|}
\hline \multicolumn{1}{|c|}{ Site } & Altitude (m) & $\begin{array}{c}\text { Average Annual Wind Speed (m/s) } \\
\text { 10-m height, assumed }\end{array}$ \\
\hline \hline Calama Airport & 2300 & 8.5 \\
\hline Montecristo site & 3000 & 6.1 \\
\hline Calama site & 2400 & 9.2 \\
\hline Montezuma site & 2350 & 7.8 \\
\hline Balmaceda & 520 & 7.5 \\
\hline
\end{tabular}

There is a very high potential for large wind system development in the northern region of Chile, near Chuquicamata. Annual wind speeds average $8.5 \mathrm{~m} / \mathrm{s}$ for $10 \mathrm{~h} /$ day for this region. Because current price for electricity generated by fossil fuels is $\$ 0.059 / \mathrm{kWh}$ in Chuquicamata and $\$ 0.075 /$ $\mathrm{kWh}$ in the nearby city of Arica, wind-generated electricity can be cost effective. Another good potential is Easter Island, where diesel-generated electricity is expensive $(\$ 0.010 / \mathrm{kWh})$ and winds blow at $6 \mathrm{~m} / \mathrm{s}$ for $6 \mathrm{~h} /$ day.

Wind can be integrated into a diesel mini-grid as a fuelsaver. Sm ll-scale wind generators can provide electricity to more than 200,000 villages that are not connected to the grid. Numerous fisheries also require electricity for refrigeration. The southern region around Punta Arenas has sufficient wind speeds to meet this need (CHL-W3).

So far, only one local manufacturer has produced a number of wind energy generators, primarily used for water pumping. Design and development of wind turbine technologies is 5 to 8 years behind the United States and Europe (CHL-W1). Furthermore, except for coastal regions, most of the tropics lie in areas of low winds. In these regions, the major success has been the design of a low-cost windmill known as "Las Gaviotas." 


\section{Solar Resources}

In Chile, solar radiation measurement equipment consists primarily of two types of instruments: (1) the Robitsch pyranograph or actinograph for measuring global radiation; and (2) the Campbell-Stokes heliograph for measuring sunshine duration. The following equation has been applied in Chile to express the regression between global radiation and sunshine duration (CHL-S3):

$$
R=R_{S}+r_{R} / s_{S}\left(S-S_{S}\right)
$$

where:

$$
\begin{aligned}
& R=\text { daily sum of global radiation } \\
& S=\text { daily sum of sunshine duration } \\
& R_{s}, S_{S}=\text { their mean values for a given month } \\
& r=\text { correlation coefficient } \\
& s_{R}=\text { standard deviation of } R \\
& S_{S}=\text { standard deviation of } S
\end{aligned}
$$

Data was obtained from 42 stations; of these, 14 had simultaneous measurements of global radiation and sunshine duration, three had only global radiation measurements, and 25 had only sunshine duration measurements.

A series of maps has been developed to illustrate the distribution of global radiation (CHL-S2). Northern Chile, close to the Andes, is characterized by a clear atmosphere that results in the world's maximum solar radiation region (CHL-S2). More than half the days throughout the year have cloudless skies (CHL-S4).

However, because of the member economy's wide range of climates (Chile stretches over 4,200 $\mathrm{km}$ from north to south), the intensity of solar radiation varies greatly from place to place (CHL-S2). For example, in the Andes, between $18^{\circ} \mathrm{S}$ and $20^{\circ} \mathrm{S}$, the station at Parinacota is representative of the solar resource in this region, and is characterized by relatively high radiation values. The rest of the region south to $32^{\circ} \mathrm{S}$ shows a definite yearly variation, as do other southern zones (CHL-S2).

\section{Geothermal Resources}

As a result of subduction of the Nazca plate under the South American plate, many active volcanoes have formed. In the Chilean area, several high-temperature geothermal systems are found. Areas near these sites are not densely populated and the demand is small, so these systems are not yet developed. The first major geothermal project was El Tatio, Chile (30 MWe). This project could provide enough energy to run the Chuquicamata copper mine located $100 \mathrm{~km}$ to the west (CHL-Gl). 
Table of References for Chile (see key following table for abbreviation and resource codes):

\begin{tabular}{|l|c|c|c|c|c|c|}
\hline \multicolumn{1}{|c|}{ Type of Analysis } & Wind & Solar & Biomass & Geothermal & Hydro & General \\
\hline \hline $\begin{array}{l}\text { Site-Specific } \\
\text { Analysis }\end{array}$ & $\begin{array}{l}\text { CHL-W1 } \\
\text { CHL-W2 } \\
\text { CHL-W4 }\end{array}$ & $\begin{array}{c}\text { CHL-S2 } \\
\text { CHL-S4 }\end{array}$ & & & & \\
\hline $\begin{array}{l}\text { Country-Wide } \\
\text { Surveys }\end{array}$ & $\begin{array}{c}\text { CHL-W1 } \\
\text { CHL-W3 } \\
\text { CHL-W4 }\end{array}$ & & & & & CHL-S4 \\
\hline $\begin{array}{l}\text { Country-Wide } \\
\text { Maps }\end{array}$ & & $\begin{array}{c}\text { CHL-S2 } \\
\text { CHL-S3 }\end{array}$ & & & & \\
\hline $\begin{array}{l}\text { Modeled Data } \\
\text { Sources }\end{array}$ & & CHL-S3 & & & & \\
\hline $\begin{array}{l}\text { Measured Data } \\
\text { Sources }\end{array}$ & CHL-W4 & $\begin{array}{c}\text { CHL-S2 } \\
\text { CHL-S3 }\end{array}$ & & & & \\
\hline $\begin{array}{l}\text { Technology or } \\
\text { Economic } \\
\text { Assessment Only }\end{array}$ & & & & CHL-G1 & & \\
\hline
\end{tabular}

Key:

$\underline{\text { Resources }}$

$\underline{\text { Abbreviations }}$

Chile $=$ CHL

South East Asia Region = SE

Wind $=\mathrm{W}$

Solar $=\mathrm{S}$

Biomass $=\mathrm{B}$

Geothermal $=\mathrm{G}$

Hydro $=\mathrm{H}$

General $=\mathbf{N}$ 


\section{People's Republic of China (PRC)}

\section{Overview of People's Republic of China's Energy Production}

The demand for electric power in PRC will grow from 1250 TWh to $1360 \mathrm{~T} h$ by the end of the decade. Yet, some 200 million people in PRC have no access to electricity (PRC-N1, PRC-N6).

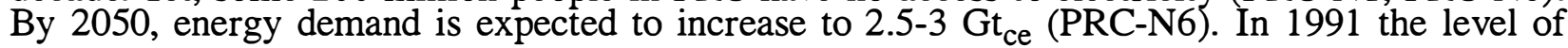
annual electrical power generation was $677.5 \mathrm{TWh}$; total electricity production in 1991 was around 670,000 GWh, but per-capita capacity was only $0.14 \mathrm{~kW}$ (PRC-W3).

A comparison of how output of PRC's main products have increased from 1978 to 1992 is shown in the following table (PRC-S5):

\begin{tabular}{|l|c|c|}
\hline \multicolumn{1}{|c|}{ Product } & 1992 Levels & \% Increase (Compared with 1978 levels) \\
\hline \hline Grain & 443 tonnes & $45 \%$ \\
\hline Total Energy & 1067 tonnes & $70 \%$ \\
\hline Electricity & 700 tonnes & $190 \%$ \\
\hline Cotton & 4.5 tonnes & $110 \%$ \\
\hline Coal & 1110 tonnes & $80 \%$ \\
\hline Steel & 80 tonnes & $150 \%$ \\
\hline
\end{tabular}

The People's Republic of China will continue to rely on coal as its major energy resource well through the first half of the next century. Coal will fulfill about $70 \%$ of total energy demand; oil and gas will provide about 6-7\% (PRC-N6, PRC-S5).

More than $70 \%$ of Chinese cities and towns have particulate emissions related to the burning of fossil fuel that exceed the national standard. In $20 \%$ of all cities and towns $\mathrm{SO}_{2}$ emissions exceed national standards as well (PRC-N6). In 1990, 13.24 tonnes of coal dust and 6.22 tonnes of $\mathrm{SO}_{2}$ were released into the air in some regions (PRC-S5). Nevertheless, in many regions, such as Inner Mongolia and Tibet, diesel fuel is less expensive than renewable alternatives (PRC-N6).

Because of shortages of coal deposits and hydropower in some areas, nuclear energy is also being developed, and will reach 3-4 GW by the year 2000 (PRC-N1). This development has occurred only during the past 20 years.

Before 1979, domestic energy use accounted for $85 \%$ of total energy use, and the main energy sources were crop stems, straw, firewood, and animal dung. By 1985 domestic energy consumption was only about $25 \%$ of the total consumption, at $154 \mathrm{~kg}_{\text {ce }} /$ person.year $(21 \mathrm{kWh} /$ person.year), which is much lower than in developed economies due to low GDP/capita (PRC-S5). 
During the 1970s the Chinese government began to consider new and renewable energy options. For PRC's 8th Five-Year Plan, 35M RMB was planned to be allocated for these projects (PRC-S5). Based on the National Self-reliance Policy, the present governmental objectives are to:

- Devote great efforts to constructing coal-fired thermal power stations, selecting high thermal efficiency large, steam-generating units of 300 to $600 \mathrm{MW}$ capacity.

- $\quad$ Adopt effective measures to develop nuclear power as quickly as possible.

- $\quad$ Promote the interconnection of provincial grids and regional networks:

- $\quad$ Diversify into wind, geothermal, tidal, and solar energies.

- $\quad$ Advocate energy conservation (PRC-N1).

To accomplish these goals, during the past 20 years PRC has funded more than 20 specialized institutes and divisions, more than 3,000 professional engineers and technicians, about 100 factories, and several national technical and training centers. Also, 23 international cooperation projects have been carried out (PRC-S5).

There are widespread energy shortages in rural areas of PRC, where $80-85 \%$ of its population lives (PRC-N2, PRC-S5). Growth of small coal mines, small-scale hydroelectric power, and fast-growing fuel forests is occurring (PRC-N2). Less than 25\% of PRC's total energy supply is from "non-commercial" energy sources (SE-N1).

\section{Wind Resources}

The world has $2 \times 10^{10} \mathrm{~kW}$ of wind energy potential; PRC has $10^{9} \mathrm{~kW}$. Of these totals, the exploitable amount is estimated to be $1.6 \times 10^{8} \mathrm{~kW}$ and $250 \mathrm{GW}$ (PRC-N5, PRC-N7). Most of PRC's wind energy potential is in the coastal and the northern (from Xinjiang and Gansu to the plateau of Inner Mongolia) "wind belts" (PRC-N7).

The average wind velocity ranges from $3.6 \mathrm{~m} / \mathrm{s}$ to $8 \mathrm{~m} / \mathrm{s}$ (SE-Nl, PRC-W10), although the anemometer heights are not specified. Much of the vast and flat northwestern portion of the member economy experiences speeds higher than $6 \mathrm{~m} / \mathrm{s}$. In the Xinjiang Autonomous region, for example, Dabancheng has $1,000 \mathrm{~km}^{2}$ with wind speeds greater than $6 \mathrm{~m} / \mathrm{s}$, suitable for large wind turbine development. This region currently has the largest wind farm installed in Chinqa, with more than 10 MW capacity, and by the year $20005 \%$ of the total generation capacity in Xinjiang will come from wind energy. Inner Mongolia's Huitenxile site is about $300 \mathrm{~km}^{2}$ in area, and about $1 \%$ of the total area has mean annual wind speeds greater than $6 \mathrm{~m} / \mathrm{s}$, and $10 \%$ has mean annual wind speeds greater than $4.5 \mathrm{~m} / \mathrm{s}$ (PRC-W10). At the Qinghai-Tibet plateau, wind energy potential is very high (wind power density is greater than $200 \mathrm{~W} / \mathrm{m}^{2}$, and a wind speed greater than $3 \mathrm{~m} / \mathrm{s}$ occurs more than $5,000 \mathrm{~h} / \mathrm{yr}$ ). All in all, the area of most favorable wind resources covers the southeastern coastal area, including 6,300 islands ${ }^{1}$, the northern part of Inner Mongolia and Gansu province, and the eastern part of Heilongjiang and Jilin provinces (PRC-S5).

In summary, then, Inner Mongolia, Fujian province, and Acilongjiang have the largest wind energy potential because of following factors (PRC-W3):

1. The island of Nan'ao has more than $8 \mathrm{~m} / \mathrm{s}$ average annual wind speed. By December 1995, total wind energy generated capacity became 8,680 kW (PRC-W10). 
- $\quad$ Duration of wind speed above $3 \mathrm{~m} / \mathrm{s}$ is greater than $5,000 \mathrm{~h}$.

- Duration of wind speed above $6 \mathrm{~m} / \mathrm{s}$ is greater than $2,200 \mathrm{~h}$.

- Wind density is greater than $200 \mathrm{~W} / \mathrm{m}^{2}$.

Sixty institutions and manufacturers are involved in developing and producing wind turbines. Already, more than 80 types of wind machines up to $20 \mathrm{~kW}$ capacity have been developed. There is a large market for $100 \mathrm{~W}$ to $300 \mathrm{~W}$ wind generators for battery charging (PRC-W3, W4). Small-scale generators (from 50-200 W to about $1 \mathrm{~kW}$ ) are at the commercial stage. Each year more than 10,000 units are sold, and about 150,000 units (17 MW total power) are in operation, $80 \%$ of these in Inner Mongolia. Somewhat larger units $(1-10 \mathrm{~kW})$ are produced on a small scale and used as stand-alone power supply for remote areas. Midsize and larger (50-200 kW) machines are undergoing on-site testing. Thirteen wind farms with a total of 163 turbines and $30,145 \mathrm{~kW}$ installed capacity have been installed through international cooperation (PRC-S5). By the beginning of the next century, wind power will account for $0.3 \%$ of PRC's generating capacity, but in Inner Mongolia it will be 2\%, and in Xinjiang 5\% (PRC-W10).

There are also 1,600 wind-powered water pumps with $2,110 \mathrm{~kW}$ capacity (PRC-N5). This will increase to 10,000 units by the year 2000. These water pumpers fall into two categories: highlifting head with small flow volume $\left(\mathrm{H}=10-146 \mathrm{~m}, \mathrm{~V}=0.5-5 \mathrm{~m}^{3} / \mathrm{h}\right)$ and low lifting head with large volume $\left(\mathrm{H}=05-3.5 \mathrm{~m}, \mathrm{~V}=50-100 \mathrm{~m}^{3} / \mathrm{h}\right)$ (PRC-S5).

\section{Solar Resources}

Solar energy resources are considered abundant in PRC, based on the following factors (PRC-N2):

- Total area is about $9.6 \mathrm{Mkm}^{2}$

- Average annual radiation is about $1,624 \mathrm{kWh} / \mathrm{m}^{2}$ per year

- Total annual solar energy is $1.9 \times 10^{12} \mathrm{t}_{\mathrm{ce}}$ (about 1,000 times the present total annual consumption)

- $\quad$ Average of 2,200 hours of annual sunshine

- $\quad$ Average solar power is $1.7 \times 10^{12} \mathrm{~kW}\left(10^{4}\right.$ times of the present generating capacity).

The annual radiation actually varies from 930 to $2,330 \mathrm{kWh} / \mathrm{m}^{2} / \mathrm{yr}$ in different places. Two-thirds of PRC has more than 2,000 hours of direct sunshine, and every year PRC receives $5 \times 10^{19} \mathrm{~kJ}$ $\left(1.4 \times 10^{17} \mathrm{kWh}\right)$ of solar energy (PRC-N5)

Research and development of solar cell technology started in 1985. Since then, 38 universities and institutions have been involved in this field, and large funds have been allocated. For the period between 1976 and 1995 more than $62 \mathrm{M} \mathrm{RMB}$ for R\&D came from the central government, and an additional $28 \mathrm{M}$ RMB came from local governments. However, these funds are considered insufficient. Large-scale production of solar cells began in 1976; 12 production lines that provided total power of $2.55 \mathrm{MW}$ in 1991 and have a total capacity of $5.5 \mathrm{MWp}$. There are also two lines for space applications (all five Chinese satellites use solar cells). In 1991, the 
total solar cell production was $700 \mathrm{~kW}$ (one-third of which was exported), and in 1992 capacity had increased to $1 \mathrm{MW}$ (PRC-S5).

So far, solar thermal power has been used mostly for solar water heaters $\left(1.5\right.$ million $\left.\mathrm{m}^{2}\right)$, passive solar houses $\left(0.29\right.$ million $\left.\mathrm{m}^{2}\right)$, solar greenhouses $\left(0.11\right.$ million $\left.\mathrm{m}^{2}\right)$, and solar driers and cookers (PRC-N5, PRC-N2). Water heaters of integrated and separated types are at a commercial stage in PRC. These systems are manufactured by more than 100 small factories with annual output of $400,000 \mathrm{~m}^{2}$; their total installed amount is $2.3 \mathrm{Mm}^{2}$. By 1989,800 passive solar houses were built with a total area of $290,980 \mathrm{~m}^{2}$. In 1994 , their total area reached $1.8 \mathrm{Mm}^{2}$. In 13 provinces 39 institutions are working on development of passive solar houses. There are also 150,000 sets of solar cookers with total aperture area of $270,000 \mathrm{~m}^{2}$ and more than 100 sets of solar driers with $13,200 \mathrm{~m}^{2}$ aperture area (PRC-S5).

Some PV stations supply rural electricity (PRC-N2). At the end of 1994, 3 MW of PV systems had been installed, roughly one-third of which were in dispersed households (PRC-S5). Two-W, $8-\mathrm{W}, 10-\mathrm{W}$, and $20-\mathrm{W}$ PV units are being mass-produced, 50-W, 100-W, 1-kW, and 10-kW systems can be ordered. One 10-kW PV power station, installed in Yu Zhong county, Ganshu province, provides lighting power for more than 130 families (PRC-S6).

The solar radiation data obtained for Hong Kong China can be used for Macau, due to similarities between the two regions. The monthly mean normals of relative humidity are high throughout the year, with a minimum of $60-65 \%$ (October-January) and a maximum of $74-78 \%$ (March-September) The bright sunshine fraction is inversely related to cloud cover. The minimum (28-34\%) occurs from February through April, and the maximum (51-58\%) occurs from July through December. Monthly mean daily total solar radiation on a horizontal surface in this region peaks during July at $4.46 \mathrm{kWh} / \mathrm{m}^{2}$ and falls to a minimum of $2.22 \mathrm{kWh} / \mathrm{m}^{2}$ (PRC-S1). Maximum sunshine duration in December is 10.8 hours and 13.4 hours in June.

The following Angstrom-type formula has been developed to calculate the global solar irradiation for the southern coastline of the PRC (PRC-S1):

$$
\mathrm{H} / \mathrm{H}_{\mathrm{O}}=0.18+0.62(\mathrm{n} / \mathrm{N})
$$

where the terms are defined as in equation (1). However, using the data for Macau obtained from 1973 to 1983, equation (PRC-1) takes the following site-specific form:

$$
\begin{aligned}
& \mathrm{H} / \mathrm{H}_{\mathrm{o}}=0.192+0.590(\mathrm{n} / \mathrm{N}) \\
& \text { (with correlation coefficient of } 0.9774)
\end{aligned}
$$

To calculate the diffuse solar irradiation for the southern PRC coastline, the following universal formula can be used (PRC-S1):

$$
\mathrm{H}_{\mathrm{d}} / \mathrm{H}=1.00-1.13 \mathrm{~K}_{\mathrm{T}}
$$

where:

$\mathrm{H}_{\mathrm{d}}$ is the monthly average daily diffuse irradiation on a horizontal surface $\mathrm{K}_{\mathrm{T}}$ is the monthly average daily clearness index (defined as $\mathrm{K}_{\mathrm{T}}=\mathrm{H} / \mathrm{H}_{\mathrm{O}}$ )

Again, using the specific data from Macau, equation (11) becomes (PRC-S1): 
$\mathrm{H}_{\mathrm{d}} / \mathrm{H}=1.020-1.157 \mathrm{~K}_{\mathrm{T}}$

(with a correlation coefficient of 0.9379 )

On average, the solar radiation during June ranges from 5.22 to $6.96 \mathrm{kWh} / \mathrm{m}^{2}$ day, and during December it ranges from 1.74 to $2.9 \mathrm{kWh} / \mathrm{m}^{2}$ day (SE-N1).

The locations with the highest annual average global horizontal solar irradiation are as follows (SE-S1):

\begin{tabular}{|l|c|}
\hline \multicolumn{1}{|c|}{ Location } & Yearly Average Radiation \\
\hline \hline Tsingtau & $4.37 \mathrm{kWh} / \mathrm{m}^{2}$ day- $^{1}$ \\
\hline Tsinau & $4.23 \mathrm{kWh} / \mathrm{m}^{2}$ day- $^{1}$ \\
\hline Shanghai & $4.23 \mathrm{kWh} / \mathrm{m}^{2}$ day- $^{1}$ \\
\hline
\end{tabular}

In western PRC, 24 million inhabitants of six provinces and autonomous regions still do not have electricity, and some 10-20\% of them will not be included in the electrification plan even after the year 2000. This area, due to its high insolation and low average ambient temperature, is the most favorable for the use of PV to provide basic electricity needs (PRC-S4).

\section{Biomass Resources}

The main biomass power resources in PRC are straw, wood, and animal dung. In 1990, 53\% of the total amount of straw, or $295 \mathrm{Mt}\left(147 \mathrm{Mt}_{\mathrm{ce}}\right)$ was used to generate energy. The amount of wood burning ( $215 \mathrm{Mt}$, or $123 \mathrm{Mt}_{\text {ce }}$ ) exceeds the reasonable cutting amount by $75 \mathrm{Mt}$. The amount of animal dung is about $300 \mathrm{Mt}$ (or $130 \mathrm{Mt}_{\mathrm{ce}}$ ), but only 7-8 Mt of dung are burned directly (PRC-S5). By the end of 1994, total biomass generating capacity was 87 MW (PRC-N7).

About 120,000 farmer households use fuel-saving stoves for direct burning, and every stove saves approximately 1 metric ton of stalk annually. There are abundant resources of energy crops in PRC (PRC-N7). The potential for biogas development in PRC is 1,000 million $\mathrm{m}^{3}$ (SE-N1). In $1990,10^{9} \mathrm{~m}^{3}$ biogas was actually produced. There are now 5,250,000 biogas pools for farmer households with $1.2 \times 10^{9} \mathrm{~m}^{3}$ annual output. Some 1,500 biogas collecting plants and 12,000 purification tanks have been built recently (PRC-S5).

While thermal biomass gasification technology is still at the beginning stage, a $140-160 \mathrm{~kW}$ gasification electric power station that uses rice husks is operating at Wu county, Jiangsu Province; and the government supports the continuous development of multiple-purpose devices (PRC-S5).

\section{Geothermal Resources}

Geothermal systems are widely distributed in the continental area of PRC. High temperatures $\left(>150^{\circ} \mathrm{C}\right)$ are found in South Tibet (Yanbajing, Naqu, Ali, Yangyi) and Tengehong, the volcanic zone of Yunnan Province (Ruidian, Rehai), and southwestern PRC. Intermediate and low temperatures are observed on the southeast coast, Chinling zones, and large-scale sedimentary basins (PRC-G1, TP-G1, PRC-S5). High heat flow zones include South Sea regions (TP-G1). 
More than 3,000 fields of hydrothermal activity are used for electric power conversion with a capacity of $20,800 \mathrm{~kW}$ (PRC-N5). The People's Republic of China currently has $30 \mathrm{MW}$ of installed geothermal capacity and is expected to expand (PRC- N7). There are 5,500 geothermal outcrops consisting of 3,000 hot springs and 2,500 wells. The total resource is estimated at $4,399,328 \times 10^{12} \mathrm{TJ}$ with the electrical power potential of $6.78 \mathrm{GW}$, and heat discharge from hot springs and wells is about 59,533 x $10^{9} \mathrm{TJ} / \mathrm{a}$ (PRC-S5). Much of this potential lies in high-temperature zones of Tibet, Yunnan, and Sichuan provinces (PRC-N7).

Since 1970, nine geothermal plants have been built, the largest being Yangbajing power station in Tibet at high temperatures of $145-172^{\circ} \mathrm{C}$ with $25.18 \mathrm{MW}$ capacity in 1994 . The station at Ali, Tibet, runs at a high temperature of $110^{\circ} \mathrm{C}$; another at Fongshun, Guandong at $>100^{\circ} \mathrm{C}$. Most other stations have low temperatures and thus cannot run cost-effectively.

The total geothermal power in PRC was $28.78 \mathrm{MW}$ at the end of 1994. Total direct utilization is approximately $1.6981 \times 10^{4} \mathrm{TJ} /$ year; the effective heat is about $30-40 \%$ (PRC-S5).

\section{Hydro Resources}

The total hydro resource in PRC is estimated at $676 \mathrm{GW}$ and $5920 \mathrm{TWh}$. The useful electric power capacity is estimated at $378 \mathrm{GW}$ and $1920 \mathrm{TWh}$, which is about $1719 \mathrm{kWh} /$ capita (PRC-S5). While the member economy has abundant hydropower resources, it operates on less than $15 \%$ of exploitable reserves (PRC-N1).

Most of PRC's hydro resources are distributed as follows: southwest, $232 \mathrm{GW}$ or $61.4 \%$, mid-south, $67.4 \mathrm{GW}$ or $17.82 \%$, northwest, $41.9 \mathrm{GW}$ or $11.1 \%$. The east, north, and northeast regions are economically developed; they have in total only $6.8 \%$. The Yangtze River has most of the resource (53.4\%), Yellow River, 6.1\%, and Zhujiang River, 5.8\%. The "Three Gorges Station" at Yangtze River project will have $17.7 \mathrm{GW}$ installed capacity and an annual production of 84 TWh (PRC-S5).

From 1949 to 1990, the installed hydropower capacity increased 225 times to reach $36 \mathrm{GW}$ with an annual production of 126.4 TWh (PRC-S5).

In rural areas, small hydropower (SHP) systems, ranging from $25 \mathrm{MW}$ to less than $1 \mathrm{MW}$, are the most successful technologies. The annual increase in SHPs during the past 20 years was 7-13\%. By 1991, there were 61,593 SHP stations in PRC, with 11.79 million kW of installed capacity, which amounts to $11 \%$ of the whole member economy electric power industry (PRC-N5).. By 1993, the annual production was 34.3 TWh. Eight hundred counties currently rely on SHP, so by the year 2000 the installed capacity may reach $20 \mathrm{GW}$ (PRC-S5). At the end of 1994, it was already $15 \mathrm{GW}$, or about $8 \%$ of PRC's total installed generation capacity. The remaining exploitable small hydro potential has been estimated at $56 \mathrm{GW}$, most of it concentrated in south/ central areas where difficult terrain isolates many provinces (PRC-N7). 
The following table demonstrates the potential for each of the mentioned resources (PRC-N7):

\begin{tabular}{|l|l|l|}
\hline \multicolumn{1}{|c|}{ Resource } & \multicolumn{1}{|c|}{ Criteria for Selection of Areas } & \multicolumn{1}{|c|}{ Areas with Significant Potential } \\
\hline \hline Small Hydro & $\begin{array}{l}\text { Provinces with remaining potential } \\
>1,000 \mathrm{MW}\end{array}$ & $\begin{array}{l}\text { Tibet, Yuman, Sichuan, Xinjiang, } \\
\text { Hunan, Hubei, Guangdong, Fujian, } \\
\text { Guizhou, Shanxi, Jiangxi, Qinghai }\end{array}$ \\
\hline Wind & $\begin{array}{l}\mathrm{W}_{\text {ave }}>200 \mathrm{~W} / \mathrm{m}^{2}, \mathrm{~V}>3 \mathrm{~m} / \mathrm{s} \text { for }>5,000 \\
\text { hours }\end{array}$ & $\begin{array}{l}\text { Southeastern coast and 6,300 islands, } \\
\text { northern Inner Mongolia and Gansu, } \\
\text { eastern Heilongiang and Jilin, } \\
\text { Xinjiang }\end{array}$ \\
\hline Solar & $\begin{array}{l}\text { Class I and II }>3,000 \text { hours/year, and } \\
>5,000 \mathrm{MJ} / \mathrm{m}^{2} \mathrm{yr}\end{array}$ & $\begin{array}{l}\text { Ningxia, mid-north Gansu, south } \\
\text { Xinjiang, Qinghai, southeastern and } \\
\text { western Tibet, northern Hebei, northern } \\
\text { Shanxi, Inner Mongolia }\end{array}$ \\
\hline Geothermal & High Temperature $>150^{\circ} \mathrm{C}$ & $\begin{array}{l}\text { Southern Tibet, western Yunnan and } \\
\text { Sichuan, Chinese Taipei, Fujian, } \\
\text { Guangdong }\end{array}$ \\
\hline Biomass & Bagasse, Forest Residues & \begin{tabular}{l} 
Yunnan, Guangdong, Guangxi \\
\hline
\end{tabular}
\end{tabular}

\section{Renewable Energy Resources for Specific Provinces}

\section{Inner Mongolia}

The province covers 1.18 million $\mathrm{km}^{2}$, much of which (74.6\%) is grassland. Inner Mongolia is experiencing an acute energy shortage (PRC-W8).

Inner Mongolia is rich in wind resources. The Huitenxile site is the most promising. This vast region $\left(300 \mathrm{~km}^{2}\right)$ is characterized by terrain where $400 \mathrm{MW}$ of WTGs can be installed. There is a possibility of this region exporting wind power to Beijing in the near future (PRC-W10). Annual mean wind speed for the entire province is about $3.7 \mathrm{~m} / \mathrm{s}$, but $80 \%$ of its area is considered usable for wind energy exploitation. In terms of wind energy it is the best region in PRC, with estimates of $2.7 \times 10^{12} \mathrm{kWh}$ (20\% of PRC's wind power). However, from July to September wind energy generation capacity decreases due to lower wind speeds (PRC-W8). The highest wind energy has been recorded at Bezhong Men, Zhuruhe, West of Xi Men, Houqi Bei, and Keyou Zhongqi (these areas comprise $7 \%$ of the total area) with a wind power density of $1,500-1,900 \mathrm{kWh} / \mathrm{m}^{2}, 7$ to $13 \mathrm{~h} /$ day with speeds greater than $6 \mathrm{~m} / \mathrm{s}$, and 300-325 days/yr with usable wind energy (PRC-S9).

The annual solar radiation in Inner Mongolia ranges from 1,333 to $1,777 \mathrm{kWh} / \mathrm{m}^{2}$. There are 2,600-3,400 sunshine hours per year, which is the second highest in PRC (PRC-W8). The highest solar energy has been recorded at A Men, North of Yi Men, Ba Men, Boatou City, and North of $\mathrm{Wu}$ Men, where the annual resource is measured at $5,190 \mathrm{MJ} / \mathrm{m}^{2}\left(1441.8 \mathrm{kWh} / \mathrm{m}^{2}\right)$ with 3,048-3,752 hours of sunshine and 300-330 days having usable solar energy (PRC-S9). However, solar resources decrease substantially in December, January, and February, causing battery failures for solar home systems (PRC-W8). 
Given these conditions, a hybrid wind-PV system appears to be an ideal solution. It has been successfully tested and welcomed by the local population. The Inner Mongolian government supports such systems as well. Two highly suitable locations have been identified (PRC-W8):

\begin{tabular}{|l|c|c|c|c|}
\hline \multicolumn{1}{|c|}{ Location } & $\begin{array}{c}\text { Average } \\
\text { Wind Speed }\end{array}$ & $\begin{array}{c}\text { Average } \\
\text { Windy } \\
\text { Days/Month }\end{array}$ & $\begin{array}{c}\text { Average } \\
\text { Average Solar } \\
\text { Radiation/Year }\end{array}$ & $\begin{array}{c}\text { Sunny } \\
\text { Days/Year }\end{array}$ \\
\hline \hline Xisu Banner & $5.3 \mathrm{~m} / \mathrm{s}$ & 25 & $1724 \mathrm{kWh} / \mathrm{m}^{2}$ & $>275$ \\
\hline Dongwu Banner & $3.8 \mathrm{~m} / \mathrm{s}$ & 18 & $1577 \mathrm{kWh} / \mathrm{m}^{2}$ & $>300$ \\
\hline
\end{tabular}

The Huitenxile area represents the most intensive effort that has been devoted to a wind park. Currently, 11 measurement stations are installed there. The average wind speed at $10 \mathrm{~m}$ height has been measured at $7.4 \mathrm{~m} / \mathrm{s}$, and at $40 \mathrm{~m}$ height at $8.5 \mathrm{~m} / \mathrm{s}$. A $250 \mathrm{~kW}$ German-made wind turbine produces an average of $687 \mathrm{MWh}$ per year at this site (PRC-W9).

\section{Tibet (Xizang Autonomous Region)}

By June 1991, there were $156 \mathrm{MW}$ of total installed capacity of 433 power plants in Tibet, including hydro, thermal, and geothermal, but excluding solar and wind (PRC-N4).

There are two wind belts in Tibet (PRC-N4):

- Northern Tibet, including the Erli region, where strong winds blow 150 days a year,

- $\quad$ Southern Tibet, between the Yarlung-Zangbo river and Himalaya mountains, where the wind density averages between 150 and $200 \mathrm{~W} / \mathrm{m}^{2}$, and where many small wind power units have been installed.

The first large (10-MW) wind power generation station was built in 1994 in Dabancheng (PRC-S5).

The city of Lhasa, the capital of Tibet, receives $140 \mathrm{kcal} / \mathrm{cm}^{2}$ of solar radiation per year and is the "sunshine city" of the member economy. Solar heat panels are being developed. A 110-kW power grid has been established in Lhasa, where $40 \%$ of all of the region's power installation is concentrated. There are plans to build 7-8 stand-alone $20-30 \mathrm{~kW}$ PV plants for regions where there is no electricity. The first 10-kW plant was set up in the Ali district in 1990, and recently a 25-kWp station in the Tibet Shuanhu district was put into operation (PRC-S5).

Geothermal energy in Tibet is the largest resource of its kind in the member economy, totaling $690,000 \mathrm{kcal} / \mathrm{s}$. More than 600 fields have been discovered. There were eight generating units with total installed capacity of $25 \mathrm{MW}$ in 1991. Geothermal energy is also cheaper than diesel (PRC-N4). There are more than 108 high-temperature geothermal fields with good potential for generating electric power. The following four locations are the most prominent (PRC-S5):

- $\quad$ Yanbajing (near Lhasa): $146 \mathrm{~km}^{2}, 172{ }^{\circ} \mathrm{C}, 50,000 \mathrm{~m}^{2}$ greenhouse, $25.18 \mathrm{MW}$ power plant. A temperature of $329.8^{\circ} \mathrm{C}$ has been found at $2006 \mathrm{~m}$ depth 
- Yangyii: more than 40 boiling springs, $\mathrm{T}_{\max }=201.8^{\circ} \mathrm{C}$, at $\mathrm{ZK} 203$ well, $237 \mathrm{t} / \mathrm{h}, 890 \mathrm{kpa}$, $5 \mathrm{MW}$ potential for power generation

- Naqu: four $105-110^{\circ} \mathrm{C}$ production wells, about $200 \mathrm{kpa}, 1 \mathrm{MW}$ power plant

- Langjiu: a potential for $2 \mathrm{MW}$ power plant.

The Yarlung-Zangbo River offers enormous hydropower potential. By 1991, 10 medium-sized and more than 300 small hydro generating stations were in operation. The Zhikong project, now in progress, will have a 100-MW capacity (PRC-N4).

\section{Yunnan Province}

Yunnan Province, located on Yunnan-Guizhou plateau, is a tropical-subtropical area of 380,000 $\mathrm{km}^{2}$. Thin plateau air, larger transmittance of sunlight, longer bright sunshine hours, and better meteorological conditions lead to a larger global solar radiation resource than in the rest of PRC; thus, this is the most favorable area for solar energy use. The global radiation incident on a horizontal surface is measured at 133 stations throughout the province. At Lijiang, Yuanyang, Yongren, and Ruili, the global solar radiation values are above $1666 \mathrm{kWh} / \mathrm{m}^{2}$ per year. Very few regions have less than $1,111 \mathrm{kWh} / \mathrm{m}^{2} /$ year, but more than $85 \%$ of the province's area has more than $1,389 \mathrm{kWh} / \mathrm{m}^{2} / \mathrm{yr}$. The minimum solar global solar radiation is less than half the maximum. The values of $\mathrm{p}$ (yearly averaged daily bright sunshine ratio) and $\mathrm{n}$ (averaged annual bright sunshine hours) are mainly above 50\% and 2,200 hours, reaching the maximums of $70 \%$ and 3,000 hours. The values of $T_{a}$ and $T_{a, m}$ (yearly averaged daily and yearly averaged minimal temperatures) are above $10^{\circ} \mathrm{C}$ and $0^{\circ} \mathrm{C}$, respectively. Thus, solar energy devices can operate year round without freeze prevention, and the utilization ratio of the devices is $100 \%$. The dry season lasts from November to April; the wet season from May through October. During the wet season, $85 \%$ of the annual precipitation occurs in the form of short showers (PRC-S3). Using the meteorological data on these seasons, the general correlations for estimating the monthly total and direct radiation are obtained through the following linear regressions (PRC-S8):

For the dry season:

$$
\begin{aligned}
& \mathrm{H} / \mathrm{H}_{\mathrm{O}}=\left(-0.17+0.03 \mathrm{~A}_{\mathrm{hd}}\right)+\left(3.22-56.51 / \mathrm{F}-3.57 / \mathrm{A}_{\mathrm{hd}}\right) \mathrm{n} / \mathrm{N}_{\mathrm{d}}^{\prime} \\
& \mathrm{H}_{\mathrm{b}} / \mathrm{H}_{\mathrm{o}}=\left(-1.05+77.3 / \mathrm{h}+8.34 / \mathrm{W}_{\mathrm{d}}\right)+\left(1.76-87.62 / \mathrm{h}-11.83 / \mathrm{W}_{\mathrm{d}}\right) \mathrm{K}_{\mathrm{t}}
\end{aligned}
$$

For the wet season:

$$
\begin{aligned}
& \mathrm{H} / \mathrm{H}_{\mathrm{o}}=\left(-0.37+17.06 / \mathrm{h}-0.01 \mathrm{~A}_{\mathrm{hw}}\right)+\left(0.34-52.24 / \mathrm{h}+0.01 \mathrm{~A}_{\mathrm{hw}}\right) \mathrm{n} / \mathrm{N}_{\mathrm{d}} \\
& \mathrm{H}_{\mathrm{b}} / \mathrm{H}_{\mathrm{o}}=\left(0.34-24.5 / \mathrm{h}-6.14 / \mathrm{C}_{\mathrm{w}}\right)+\left(-3054+77.0 / \mathrm{h}+36.7 / \mathrm{C}_{\mathrm{w}}\right) \mathrm{K}_{\mathrm{t}}
\end{aligned}
$$

where all terms are defined as before, in addition to:

$\mathrm{H}_{\mathrm{b}}$ is monthly direct radiation incident on a horizontal surface,

$F$ is latitude, degrees

$\mathrm{h}$ is elevation, $\mathrm{m}$

$\mathrm{N}_{\mathrm{d}^{\prime}}, \mathrm{N}_{\mathrm{d}}$ is monthly average daily length, hour

$A_{\text {hd }}, A_{\text {hw }}$ is monthly average daily absolute humidities during the dry and wet seasons, respectively

$\mathrm{C}_{\mathrm{w}}$ is seasonally averaged daily total cloudiness during the wet season 
A general correlation for estimating the monthly daily average direct radiation $\mathrm{H}_{\mathrm{b}}$ incident on any horizontal surface is as follows (PRC-S7):

For the dry season:

$$
\mathrm{H}_{\mathrm{b}} / \mathrm{H}_{\mathrm{o}}=\left(-1.05+77.3 / \mathrm{h}+8.34 / \mathrm{W}_{\mathrm{d}}\right)+\left(1.76-87.62 / \mathrm{h}-11.83 / \mathrm{W}_{\mathrm{d}}\right) \mathrm{K}_{\mathrm{t}}
$$

For the wet season:

$$
\mathrm{H}_{\mathrm{b}} / \mathrm{H}_{\mathrm{o}}=\left(0.34-24.5 / \mathrm{h}-6.14 / \mathrm{C}_{\mathrm{w}}\right)+\left(-3.54+77.0 / \mathrm{h}+36.70 / \mathrm{C}_{\mathrm{w}}\right) \mathrm{K}_{\mathrm{t}}
$$

where, in addition to the terms already defined:

$\mathrm{W}_{\mathrm{d}}$ is seasonally averaged monthly total precipitation, $\mathrm{mm}$

Mountain areas in the northwest and northeast have relatively low temperatures, river-valley areas in the south and southeast have medium temperatures, and June, July, and August's climate can last the entire year. The central part has an average of $15^{\circ} \mathrm{C}$ air temperature with a small annual temperature difference year to year, but large diurnal temperature differences (PRC-S3). The annual global solar radiation ranges from 1,250 to $1,666 \mathrm{kWh} / \mathrm{m}^{2}$. Overall, Yunnan has abundant solar resources and is ideal for solar energy use (PRC-S3).

Feasibility studies show that biomass projects in Yunnan Province are financially viable. Biomass can be grown and converted to electricity at costs lower than other alternatives, including coal (PRC-N2).

\section{Xinjiang Uygnr Zizhigi Province (PRC-W1)}

The annual average wind velocity is $6.7 \mathrm{~m} / \mathrm{s}$. The available area for wind turbine installations is greater than $1000 \mathrm{~km}^{2}$. The annual amount of wind generation is calculated at $8.62 \times 10^{9} \mathrm{kWh}$. However, the electricity generated through burning of coal is about three times cheaper (10.3 $\mathrm{kW}$ versus $37 ¥ / \mathrm{kW}$ ) The author of the cited publication also stated that construction of wind facilities would emit more carbon dioxide $\left(\mathrm{CO}_{2}\right)$ than a coal thermal plant. However, over the long run wind energy is far more environmentally friendly than coal.

\section{Fujian Province (PRC-W7)}

The wind resources are the greatest at the exposed islands and peninsulas along the coast. The annual available wind power ranges from 2,500 to $6,500 \mathrm{kWh} / \mathrm{m}^{2}$, the annual available frequency is more than $70 \%$. On islands protected by bays and offshore areas within $20 \mathrm{~km}$ of the coast, the available wind power is lower, $300-2,500 \mathrm{kWh} / \mathrm{m}^{2}$, and the frequency of power-produsing winds is between 30 and $70 \%$. The lowest wind power occurs in inland regions, where it is less than 300 $\mathrm{kWh} / \mathrm{m}^{2}$, with frequency being not more than $30 \%$. The best season for wind power in all cases is from September to March. The highest wind speeds occur between 8:00 am and 6:00 pm, when the demand for electricity is at its maximum. The following table shows the wind energy data for five Fujian locations: 


\begin{tabular}{|l|c|c|c|}
\hline & $\begin{array}{c}\text { Yearly Mean Wind } \\
\text { Speeds }\end{array}$ & $\begin{array}{c}\text { Yearly Effective } \\
\text { Wind Frequencies }\end{array}$ & $\begin{array}{c}\text { Yearly Available } \\
\text { Wind Energy }\end{array}$ \\
\hline \hline Tai Shan & $8.2 \mathrm{~m} / \mathrm{s}$ & $85 \%$ & $4705 \mathrm{kWh} / \mathrm{m}^{2}$ \\
\hline Dong Shan & $7.0 \mathrm{~m} / \mathrm{s}$ & $77 \%$ & $3477 \mathrm{kWh} / \mathrm{m}^{2}$ \\
\hline Chung Wu & $6.7 \mathrm{~m} / \mathrm{s}$ & $75 \%$ & $3177 \mathrm{kWh} / \mathrm{m}^{2}$ \\
\hline Ping Tan & $6.5 \mathrm{~m} / \mathrm{s}$ & $74 \%$ & $2976 \mathrm{kWh} / \mathrm{m}^{2}$ \\
\hline Bei Jiao & $6.4 \mathrm{~m} / \mathrm{s}$ & $73 \%$ & $2706 \mathrm{kWh} / \mathrm{m}^{2}$ \\
\hline
\end{tabular}

Other positive factors include long periods of steady high wind power levels, stability of wind direction, and correlation with electrical diurnal and seasonal demand patterns. For the coastal island and peninsula, already served by the Provincial network, the best way of using supplementary wind power would be to interconnect large and medium-sized wind generators. For areas not served by the network and relying on diesel power, small and medium-sized wind turbines can be incorporated into individual network consisting of wind-diesel systems. For areas where there is no electricity, small aerogenerators with energy storage systems could be deployed. 
Table of References for the People's Republic of China (see key following table for abbreviation and resource codes):

\begin{tabular}{|c|c|c|c|c|c|c|}
\hline Type of Analysis & Wind & Solar & Biomass & Geothermal & Hydro & General \\
\hline $\begin{array}{l}\text { Site-Specific } \\
\text { Analysis }\end{array}$ & $\begin{array}{l}\text { PRC-W1 } \\
\text { PRC-W3 } \\
\text { CHL-W7 } \\
\text { PRC-W8 } \\
\text { PRC-W10 } \\
\text { PRC-N4 }\end{array}$ & $\begin{array}{l}\text { PRC-N1 } \\
\text { PRC-S1 } \\
\text { PRC-S3 } \\
\text { PRC-S7 } \\
\text { PRC-S8 } \\
\text { PRC-W8 }\end{array}$ & $\begin{array}{l}\text { PRC-B1 } \\
\text { PRC-N4 }\end{array}$ & PRC-N4 & PRC-N4 & PRC-N4 \\
\hline $\begin{array}{l}\text { Country-Wide } \\
\text { Surveys }\end{array}$ & $\begin{array}{l}\text { PRC-N5 } \\
\text { PRC-N7 } \\
\text { PRC-W9 } \\
\text { PRC-W10 } \\
\text { PRC-S5 }\end{array}$ & $\begin{array}{l}\text { PRC-N5 } \\
\text { PRC-S5 }\end{array}$ & $\begin{array}{l}\text { PRC-N7 } \\
\text { PRC-S5 }\end{array}$ & $\begin{array}{l}\text { PRC-G1 } \\
\text { PRC-N7 } \\
\text { CT-G1 }\end{array}$ & $\begin{array}{l}\text { PRC-N1 } \\
\text { PRC-N7 } \\
\text { PRC-S5 }\end{array}$ & $\begin{array}{l}\text { PRC-N1 } \\
\text { PRC-N2 } \\
\text { PRC-N3 }\end{array}$ \\
\hline Country-Wide Maps & $\begin{array}{l}\text { PRC-W3 } \\
\text { PRC-W10 }\end{array}$ & PRC-S10 & & & & \\
\hline $\begin{array}{l}\text { Modeled Data } \\
\text { Sources }\end{array}$ & & $\begin{array}{l}\text { PRC-S1 } \\
\text { PRC-S3 } \\
\text { PRC-S7 } \\
\text { PRC-S8 }\end{array}$ & & & & \\
\hline $\begin{array}{l}\text { Measured Data } \\
\text { Sources }\end{array}$ & $\begin{array}{c}\text { PRC-N5 } \\
\text { PRC-N6 } \\
\text { PRC-N7 } \\
\text { PRC-W1 } \\
\text { PRC-W3 } \\
\text { PRC-W7 } \\
\text { PRC-W8 } \\
\text { PRC-W9 } \\
\text { PRC-W10 } \\
\text { PRC-S5 } \\
\text { SE-N1 }\end{array}$ & $\begin{array}{c}\text { PRC-N4 } \\
\text { PRC-N5 } \\
\text { PRC-N6 } \\
\text { PRC-N-7 } \\
\text { PRC-S5 } \\
\text { PRC-S6 } \\
\text { PRC-S7 } \\
\text { PRC-S8 } \\
\text { PRC-W8 } \\
\text { SE-N1 } \\
\text { SE-S1 }\end{array}$ & $\begin{array}{l}\text { PRC-N4 } \\
\text { PRC-N5 } \\
\text { PRC-N6 } \\
\text { PRC-S5 }\end{array}$ & $\begin{array}{c}\text { PRC-N4 } \\
\text { PRC-N5 } \\
\text { PRC-N6 } \\
\text { PRC-N7 } \\
\text { SE-S1 }\end{array}$ & $\begin{array}{l}\text { PRC-N4 } \\
\text { PRC-N5 } \\
\text { PRC-N6 } \\
\text { PRC-N7 } \\
\text { PRC-S5 }\end{array}$ & $\begin{array}{l}\text { PRC-N1 } \\
\text { PRC-N6 } \\
\text { PRC-S5 } \\
\text { PRC-W3 }\end{array}$ \\
\hline $\begin{array}{l}\text { Technology or } \\
\text { Economic } \\
\text { Assessment Only }\end{array}$ & PRC-W3 & $\begin{array}{l}\text { PRC-S5 } \\
\text { PRC-N2 } \\
\text { PRC-N5 } \\
\text { PRC-N6 }\end{array}$ & $\begin{array}{l}\text { PRC-N7 } \\
\text { PRC-S5 }\end{array}$ & PRC-N5 & PRC-N5 & $\begin{array}{l}\text { PRC-N1 } \\
\text { PRC-S5 }\end{array}$ \\
\hline \multicolumn{4}{|l|}{ Key: } & \multicolumn{3}{|l|}{$\underline{\text { Resources }}$} \\
\hline \multicolumn{4}{|c|}{$\begin{array}{l}\text { Abbreviations } \\
\text { People's Republic of China = PRC } \\
\text { Chile }=\text { CHL } \\
\text { South East Asia Region = SE } \\
\text { Chinese Taipei = CT }\end{array}$} & \multicolumn{3}{|c|}{$\begin{array}{l}\text { Wind }=\mathrm{W} \\
\text { Solar }=\mathrm{S} \\
\text { Biomass }=\mathrm{B} \\
\text { Geothermal = G } \\
\text { Hydro }=\mathrm{H} \\
\text { General }=\mathrm{N}\end{array}$} \\
\hline
\end{tabular}




\section{Hong Kong, China (HKC)}

\section{Overview of Hong Kong, China's Energy Production}

Hong Kong, China has no fossil or hydro resources, so all of its energy is imported. As electrical generating stations switch from oil to coal, imports are increasing $8 \% / y e a r$. During the past decade, the annual growth in energy consumption has averaged $9 \%$ due to $10.4 \%$ annual growth in GDP (HKC-N1, HKC-N2).

Even though Hong Kong, China lies within the tropics, it experiences distinct seasonal changes in weather. The December, January, and February monsoon blows from the north and northeast, and there are frequent outbreaks of cold from November through February. During the colder months the mean monthly temperatures range from $15-18^{\circ} \mathrm{C}$, but daily temperatures can fall to $10^{\circ} \mathrm{C}$. January and February are colder, with mean monthly temperatures of $16^{\circ} \mathrm{C}$; December and March are somewhat warmer, with mean monthly temperatures of $18^{\circ} \mathrm{C}$. March and April are characterized by cloudy skies, humid conditions, and wide temperature fluctuations. From May through August, the monsoon blows from the south or southeast, and the weather is typically hot and humid. During this time, mean monthly temperatures range from $27-29^{\circ} \mathrm{C}$. Typhoons are common from July to September. Often, they bring rain and strong hurricane-like winds and can last for several days. From mid-September to November, typhoons and clouds diminish rapidly. The temperatures often climb above $30^{\circ} \mathrm{C}$. The wettest month in Hong Kong, China is usually July, the driest is December (HKC-S3). The monthly mean relative humidity remains high throughout the year. The maximum occurs from March to September at $74-78 \%$, and the minimum is from October to January at $60-65 \%$ (PRC-S1).

The heating season in Hong Kong, China is short, so the main energy need is for cooling and refrigeration. An experimental solar-powered air-conditioning system was constructed on the campus of the Hong Kong, China University. The system included a $38.2 \mathrm{~m}^{2}$ flat plate collector array. It demonstrated an annual efficiency of $7.8 \%$ and an average solar fraction of $55 \%$ (HKC-S4).

Virtually all renewable energy activity in the member economy has focused on the use of solar energy. For the past 25 years, solar energy research has been progressing, particularly during energy crises. Considerable success has been achieved with respect to PV technologies. A $16 \%$ efficient cell is commercially available, a $20.8 \%$ efficient solar module has been tested in the laboratory, and the manufacture of a $24 \%$ efficient cell from low-cost multi-layers has been initiated (HKC-S6).

The member economy has an abundant, reliable supply of grid-connected electricity that exceeds even peak demand. This is quite unusual for an APEC member economy in southeast Asia. Locally generated electricity is a part of the grid. Thus, more investment is allocated to PV clading and shading devices integrated in buildings (HKC-S6).

\section{Solar Resources}

Measurements of the daily total global solar irradiance and duration of bright sunshine have been made since 1958 using a bimetallic actinograph (British Office Pattern Mk III) and a Campbell-Stokes sunshine recorder. For hourly measurements, a sealed thermopile dome solarimeter (thermo-electric pyranometer) was used between December 1978 and November 1979, and published by the Royal Observatory (HKC-S3). 
From these measurements, the annual total global solar irradiance on a horizontal surface ranged between 1323.72 and $1675.1 \mathrm{kWh} / \mathrm{m}^{2}$ with a mean of about $1505.9 \mathrm{kWh} / \mathrm{m}^{2}$ for the period 1969-1978. The average daily global total values range from $5.23 \mathrm{kWh} / \mathrm{m}^{2}$ day- ${ }^{1}$ in July to 3.19 $\mathrm{kWh} / \mathrm{m}^{2}$ day- ${ }^{1}$ in January. The average daily value is around $4.41 \mathrm{kWh} / \mathrm{m}^{2}$ day during the year. The year-to-year variability is small, but is relatively large from month to month. March and November have the greatest variation because of unstable climatic conditions, but May's variation is the smallest (HKC-S3).

In 1991, a measuring station was set up at City Polytechnic of Hong Kong, China to measure hourly global and diffuse solar radiation, using two Kipp and Zonen pyranometers. This allowed us to obtain more detailed data on Hong Kong, China's solar resources (HKC-S5). Monthly daily global values fluctuate from $5.11 \mathrm{kWh} / \mathrm{m}^{2}$ in July to $2.36 \mathrm{kWh} / \mathrm{m}^{2}$ in March. Diffuse values range from $2.3 \mathrm{kWh} / \mathrm{m}^{2}$ in May to $1.67 \mathrm{kWh} / \mathrm{m}^{2}$ in February. Daily direct values range from 2.94 $\mathrm{kWh} / \mathrm{m}^{2}$ in July to $1.39 \mathrm{kWh} / \mathrm{m}^{2}$ in February. The annual average daily total global horizontal radiation was measured at $3.72 \mathrm{kWh} / \mathrm{m}^{2}$ (which differs from $4.41 \mathrm{kWh} / \mathrm{m}^{2}$ obtained in earlier studies); diffuse at $1.89 \mathrm{kWh} / \mathrm{m}^{2}$ and direct at $1.83 \mathrm{kWh} / \mathrm{m}^{2}$. The peak global radiation occurs in July due to stable climatic conditions and high air temperatures. Unstable weather results in low global radiation in March and April. In May and November, sudden changes in solar radiation values are common, due to weather changes. The cooling season from May to October is characterized by large solar radiation values. Electricity consumption tends to rise in May and decrease in October because of high demand for air conditioning during June, July and August.

Data obtained from 1973 to 1983 in Macau (PRC) has been used to estimate the global solar radiation in Hong Kong, China by applying the following Angstrom relationship (PRC-S1):

$$
\begin{aligned}
& \mathrm{H} / \mathrm{H}_{\mathrm{o}}=0.192+0.590(\mathrm{n} / \mathrm{N}) \\
& \text { (with correlation coefficient of } 0.9774 \text { ) }
\end{aligned}
$$

The terms have been defined in previous sections (see Australia).

Maximum sunshine duration in December is 10.8 hours, in June is 13.4 hours for Macau (PRC-S1). In June, July, and August, irradiance intensities above $5.56 \mathrm{kWh} / \mathrm{m}^{2}$ occur much more often than in December, January, and February. More than 14\% of daily total solar irradiance is received in the 2 hours before and after solar noon. July has the largest mean value of bright sunshine at 214.7 hours; March has the lowest at 100.6 hours. In general, July and August are the best months for solar radiation (HKC-S1).

The average daily diffuse solar irradiance fraction of the daily total on a horizontal surface, $\mathrm{H}_{\mathrm{d}} / \mathrm{H}$, can be correlated to the cloudiness/clearness index $\mathrm{K}_{\mathrm{T}}$. $\left(\mathrm{K}_{\mathrm{T}}\right.$ is the fraction of the mean daily extraterrestrial horizontal irradiance, $\mathrm{H}_{\mathrm{o}}$, arriving at the surface of the earth: $\mathrm{K}_{\mathrm{T}}=\mathrm{H} / \mathrm{H}_{\mathrm{o}}$ ) The highest fraction of diffuse solar irradiance occurs in March, and the lowest in November. Over the course of the year, the estimated fraction may vary from 0.601 to 0.354 . The monthly average daily diffuse solar irradiance is high in June, July, and August at $2.05 \mathrm{kWh} / \mathrm{m}^{2}$ day- ${ }^{1}$ and low in December, January and February at $1.23 \mathrm{kWh} / \mathrm{m}^{2}$ day- ${ }^{1}$. To estimate the diffuse component, the data from Macau, PRC, can be used in the following equation (PRC-S1):

$$
\mathrm{H}_{\mathrm{d}} / \mathrm{H}=1.020+(-1.157)\left(\mathrm{H} / \mathrm{H}_{\mathrm{o}}\right)
$$

(with correlation coefficient of 0.9379 ) 
During the periods with low global radiation, the diffuse component is high. The following regressions equation shows a correlation between them (HKC-S5):

$$
\mathrm{H}_{\mathrm{b}}=(0.73 \mathrm{H}-880.8) \mathrm{Wh} / \mathrm{m}^{2} \quad\left(\text { for } \mathrm{H}>2500 \mathrm{Wh} / \mathrm{m}^{2}\right)
$$

The highest $\mathrm{K}_{\mathrm{T}}$ (clearness index) occurs in October at 0.52, the lowest in April at 0.24 (HKC-S5).

Yet another estimate (SE-S1) shows that throughout the year Hong Kong, China's average global horizontal solar radiation is approximately $4.37 \mathrm{kWhm}-{ }^{2}$ day- ${ }^{1}$.

After examining these estimates of solar radiation in Hong Kong, China, it is easy to conclude that a consensus is yet to be achieved. If daily average insolation of solar energy is approximately $4.23 \mathrm{kWh} / \mathrm{m}^{2}$ and the total area is $1000 \mathrm{~km}^{2}$, the potential energy is $5.4 \times 10^{12} \mathrm{MJ}$. However, given the substantial monthly variations, a large-capacity storage system would be needed to compensate for periods when there is little or no bright sunshine (HKC-S3).

Table of References for Hong Kong, China (see key following table for abbreviation and resource codes):

\begin{tabular}{|c|c|c|c|c|c|c|}
\hline Type of Analysis & Wind & Solar & Biomass & Geothermal & Hydro & General \\
\hline $\begin{array}{l}\text { Site-Specific } \\
\text { Analysis }\end{array}$ & & HKC-S4 & & & & \\
\hline $\begin{array}{l}\text { Country-Wide } \\
\text { Surveys }\end{array}$ & & $\begin{array}{l}\text { HKC-S1 } \\
\text { HKC-S3 }\end{array}$ & & & & $\begin{array}{l}\text { PRC-S1 } \\
\text { HKC-S3 }\end{array}$ \\
\hline \multicolumn{7}{|l|}{ Country-Wide Maps } \\
\hline $\begin{array}{l}\text { Modeled Data } \\
\text { Sources }\end{array}$ & & $\begin{array}{l}\text { HKC-S1 } \\
\text { HKC-S5 } \\
\text { PRC-S1 }\end{array}$ & & & & \\
\hline $\begin{array}{l}\text { Measured Data } \\
\text { Sources }\end{array}$ & & $\begin{array}{c}\text { HKC-S3 } \\
\text { HKC-S5 } \\
\text { PRC-S1 } \\
\text { SE-S1 }\end{array}$ & & & & \\
\hline $\begin{array}{l}\text { Technology or } \\
\text { Economic } \\
\text { Assessment only }\end{array}$ & & HKC-S6 & & & & $\begin{array}{l}\text { HKC-N1 } \\
\text { HKC-N2 }\end{array}$ \\
\hline
\end{tabular}

Key:

\section{$\underline{\text { Abbreviations }}$}

Hong Kong, China $=$ HKC

People's Republic of China $=$ PRC

South East Asia Region = SE $\underline{\text { Resources }}$

Wind $=\mathrm{W}$

Solar $=S$

Biomass $=\mathrm{B}$

Geothermal $=\mathrm{G}$

Hydro $=\mathrm{H}$

General $=\mathrm{N}$ 


\section{Indonesia (INA)}

\section{Overview of Indonesia's Energy Production}

Indonesia consists of 17,500 islands, divided into three major regions: Oriental, Australian, and Wallacea, with a total population of 200 million (IN-N3). Oil has been the major source of energy, followed by wood (INA-N2).

The National Energy Planning in Indonesia has two major characteristics:

- It emphasizes planning of commercial energy, particularly of fossil fuels, such as oil, gas, coal, and electric power generation from these sources, and from hydropower.

- $\quad$ The whole Indonesian archipelago is considered as a homogeneous entity, without taking into account each region's specific needs (INA-N2).

Most of the member economy's electricity is provided by the State Electricity Corporation (PLN). The PLN provides electricity to $30 \%$ of Indonesia's population. By the end of the first long-term (25-year) development plan, the total installed generation capacity will be around 21,596 MW, of which $61 \%$ will belong to PLN (INA-W1).

In 1991, only $36 \%$ of the villages in Indonesia had electricity (INA-N3). By the year 2000, the percentage of fossil fuels in meeting the total energy supply (of which $6.5 \%$ is electricity) will grow to $70 \%$; the share of biomass fuel use will decrease from $35 \%$ to $25 \%$ (INA-N2). Currently, coal use is growing annually at $18.1 \%$, oil is growing at $8.27 \%$, and natural gas is growing at $15.4 \%$ (INA-W1). The demand for electricity is growing at $15.9 \%$ annually, but per-capita consumption remains low at $337 \mathrm{kWh}$ (INA-W1). Because the GDP and living standards are increasing, the demand for electricity will increase as well. The member economy as a whole will have to develop up to $24,000 \mathrm{MW}$ of new capacity during the next 10 years at the cost of $\$ 60$ billion (INA-N4).

The following table shows Indonesia's energy consumption levels compared with a few of its Asean neighbors (SE-N3):

\begin{tabular}{|l|c|}
\hline \multicolumn{1}{|c|}{ Country } & Per-Capita Energy Consumption (toe) \\
\hline \hline Brunei & 3.80 \\
\hline Indonesia & 0.23 \\
\hline Malaysia & 0.78 \\
\hline Philippines & 0.38 \\
\hline Singapore & 4.46 \\
\hline Thailand & 0.33 \\
\hline
\end{tabular}

The breakdown of Indonesia's resources and reserves is as follows (SE-N3): 


\begin{tabular}{|c|c|c|c|c|}
\hline Oil & Gas & Coal & Hydro & Geothermal \\
(billion bbl) & (trillion $\mathrm{m}^{3}$ ) & $\begin{array}{c}\text { (billion } \\
\text { tonnes) }\end{array}$ & MW & MW \\
\hline \hline 11,000 & 76,000 & -- & 75,000 & 10,000 \\
\hline
\end{tabular}

Some $80 \%$ of the Indonesian population lives in rural areas. Isolated settlements depend heavily on locally available energy resources, mainly biomass, which comprises $45 \%$ of total energy consumption (INA-N2). Energy supply from outside is not feasible since it would be too expensive to deliver by airplane due to low demand and long distances. Nevertheless, in many of these areas, people cannot rely on indigenous sources of energy without damaging the environment. Therefore, regional planning is a necessity (INA-N2).

In west Java province, energy consumption is dominated by petroleum (50\%), followed by biomass (33\%), electricity from the State Electric Power Company (4\%), and other sources, such as coal, gas, LPG, and charcoal (13\%). Total consumption is 563.51 million GJ or 93.5 million barrels of oil equivalent (BOE). The total energy available is 871.59 million GJ or $150.27 \mathrm{BOE}$. Of this number, $57 \%$ is biomass, $31 \%$ is petroleum, and $2 \%$ is hydropower and geothermal. There are no shortages of fuelwood at the provincial level, but there are some at the district level (INA-N2).

\section{Wind Resources}

Wind energy has been used for small-scale electricity generation (500-1,000 watts). There are likely to be vast wind resources on the southern side of islands, but no extensive wind resource assessment has yet been conducted (INA-W1). Currently, NREL is conducting advanced wind mapping for several islands. Available data indicates that annual average wind speeds range between $3.6 \mathrm{~m} / \mathrm{s}$ and $8 \mathrm{~m} / \mathrm{s}$, but conventional measurements often underestimate the true level and extent of the available wind resource (SE-N1).

\section{Solar Resources}

Indonesia typically has 6 hours of daily direct solar radiation duration because of its tropical climate (INA-N3). As with wind resources, though, local conditions may vary considerably, as eight major climatic zones have been identified. The wet season can last 4 months or longer for most islands, except for the southeastern part of Indonesia, east of Bali to Timor (INA-S1).

Kipp and Zonen Model CM3 pyranometers, which use a Moll thermopile and recording millivoltmeter XR4, are used to measure solar radiation at several member economy weather stations (INA-S1). This study reports on data at 10 stations in Indonesia, one in Singapore, and one in Australia.

Evaluations of the solar resource at several points in Indonesia reveal the following results (INA-Sl). Semerang, Java, has the highest daily total global horizontal solar irradiation, ranging from approximately 5 to $6.39 \mathrm{kWh} / \mathrm{m}^{2}$; Bandung has the lowest. Other locations, except Kupang and Denpasar, have uniform solar irradiation ranging from 4.17 to $5.56 \mathrm{kWh} / \mathrm{m}^{2}$ throughout the year. In Kupang, maximums occur from October through November, minima from April through May, which is similar to Darwin, Australia (see discussion under "Australia"), although weather 
conditions are much less clear. The highest irradiation occurs when the sun is over the equator from March through April and from September through October. The lowest radiation occurs when the sun is in the north and south solstices, from December through January and from June through July. In Kupang, only $30 \%$ of days have irradiation less than $4.17 \mathrm{kWh} / \mathrm{m}^{2}$, and its distribution is very seasonal, with clear conditions in July and September. More than $60 \%$ of days in Kupang have irradiation between 4.17 to $5.56 \mathrm{kWh} / \mathrm{m}^{2}$. In Denpasar, only $25 \%$ of days have irradiation less than $4.17 \mathrm{kWh} / \mathrm{m}^{2}$ and $28 \%$ of days throughout the year have irradiation greater than $5.56 \mathrm{kWh} / \mathrm{m}^{2}$. Denpasar's solar irradiation is, overall, greater than Kupang's (4.9 compared to $4.4 \mathrm{kWh} / \mathrm{m}^{2}$ ), and there is less seasonal variation. Some areas, such as Singapore and Jakarta, have annual irradiation less than $1.53 \mathrm{kWh} / \mathrm{m}^{2}$, but the diffuse irradiation component is high because of clouds and humidity. In Jakarta, $53 \%$ of the days have irradiation less than $4.17 \mathrm{kWh} /$ $\mathrm{m}^{2}$ throughout the year and the irradiation distribution is very uniform. Jakarta's rainy season is in January, leading to lower ambient temperatures of around $25.3^{\circ} \mathrm{C}$. The dry season is characterized by July's high ambient temperatures (reaching a maximum of $32.2^{\circ} \mathrm{C}$ ) and the mean of $27.3^{\circ} \mathrm{C}$. October is a transitional period, with the highest monthly mean, at $27.6^{\circ} \mathrm{C}$. January's mean temperatures are the lowest, reaching a minimum of $23.2^{\circ} \mathrm{C}$. The hourly clearness index at Denpasar and Kupang range from 0.6 to 0.65 and from 0.7 to 0.75 ; in Jakarta it ranges from 0.2 to 0.6 and peaks at 0.4. In all three locations there is little variation of daily average temperature throughout the year, a fact that has proven to be consistent for 30 years at 10 stations.

Overall, in western Indonesia low irradiation and uniform conditions are observed; in the east clear conditions and seasonality are observed. The length for hourly radiation data records for Jakarta is 7.5 years, Denpasar is 3 years, and Kupang is 5 years. This is insufficient for establishing a long-term statistical analysis; statistical comparison requires at least 20 years of data (INA-S1).

Overall the annual solar resource in Indonesia ranges from 4.06 to $4.64 \mathrm{kWh} / \mathrm{m}^{2}$ day- ${ }^{1}$ (SE-N1).

The diffuse solar radiation component for Indonesia has been estimated using Hawlader's model for correlating hourly diffuse radiation $\left(\mathrm{H}_{\mathrm{d}} / \mathrm{H}\right)$ with hourly clearness index $\mathrm{K}_{\mathrm{T}}$ for Singapore (INA-S1):

$$
\begin{aligned}
& \mathrm{H}_{\mathrm{d}} / \mathrm{H}=0.915\left(\text { for } 0<\mathrm{K}_{\mathrm{T}}<0.225\right) \\
& \mathrm{H}_{\mathrm{d}} / \mathrm{H}=1.135-0.9422 \mathrm{~K}_{\mathrm{T}}-0.3878 \mathrm{~K}_{\mathrm{T}}^{2}\left(\text { for } 0.225<\mathrm{K}_{\mathrm{T}}<0.775\right) \\
& \mathrm{H}_{\mathrm{d}} / \mathrm{H}=0.215\left(\text { for } \mathrm{K}_{\mathrm{T}}>0.775\right)
\end{aligned}
$$

So far, solar energy (mainly PV systems) have been use for rural electrification, water pumping, television, telecommunication, and refrigeration. Total installed capacity is approximately 2.9 MWp. PV systems have proven to be cost effective for household electricity needs (INA-W1). With assistance from Japan, Indonesia has established many PV village demonstrations (SE-N1).

\section{Biomass Resources}

The total land area of Indonesia amounts to 192 million ha. More than $75 \%$ of this area (or about 143 million ha) is natural forest, which represents the country's largest biomass resource. Indonesia leads the region's timber production; thus, special emphasis is placed on the development of its forest products industry, which brings more than $\$ 3.5$ billion in export revenue. Most of it is associated with the plywood industry, the second largest in the world after 
the United States of America (6 million $\mathrm{m}^{3}$ production in 1988), The productive forest dedicated to industrial logging is 64 million ha; the average commercial species volume is around $50 \mathrm{~m}^{3}$. Waste residue generated by the sawtimber and plywood industries in 1984 was about 16 million $\mathrm{m}^{3}$, enough to support more than 10 million $\mathrm{m}^{3}$ of annual particle-board production capacity (INA-B1).

The potential for biogas development in Indonesia is 15.8 million $\mathrm{m}^{3}$ (SE-N1).

\section{Geothermal Resources}

The Indonesian Archepelego, formed by regional tectonic stretches from northern Sumatera through Java to Flores and beyond, is one of the greatest volcanic regions in the world. As a result of regional studies begun in 1974, some 217 locations were identified for geothermal exploration. The potential has been estimated from 16,000 MW to 19,600 MW. The implemented power and present development are quite small, however. By the year 1999, 1,000 $\mathrm{MW}_{\mathrm{e}}$ capacity is planned, and by $2019,4,000 \mathrm{MW}_{\mathrm{e}}$. Currently, Indonesia is the world's fifth largest producer and user of geothermal energy, at 309.5 MW (IN-G3, IN-N3). The usage rates have increased from 143,000 BOE in 1982-1983 to 2,020 million BOE in 1992-1993 (IN-W1). With all the planned activity, Indonesia can become the world's leader in geothermal power generation by 2019 (INA-G3).

The 217 locations mentioned above are distributed as follows (IN-G3):

\begin{tabular}{|l|c|c|c|}
\hline \multicolumn{1}{|c|}{ Region } & Prospects & Resources & Reserves \\
\hline \hline Sumatera Island & 74 & $9,562 \mathrm{MW}$ & 3,758 MW \\
\hline Java and Bali & 62 & $5,681 \mathrm{MW}$ & $4,236 \mathrm{MW}$ \\
\hline Sulawesi & 51 & $1,565 \mathrm{MW}$ & $490 \mathrm{MW}$ \\
\hline Remaining islands & 30 & $2,850 \mathrm{MW}$ & $490 \mathrm{MW}$ \\
\hline
\end{tabular}

This table highlights the comparative differences in geothermal resource distribution. Sumatera Island is, overall, the richest island in geothermal resource. However, its reserves are smaller than those of Java and Bali.

During the past 20 years, more than 55 high enthalpy geothermal areas have been found and developed on the islands of Sumatera, Java, Sulawesi, and Eastern Indonesia. Some of them have been used for electricity generation, such as Kamojang (140 MW) and Dieng (2 MW), plus Darajat, Salak, and Lahendong. There is intense development in Ulumbu, a geothermal area in Manggarai, in Western Flores (INA-G1, INA-G2).

\section{Hydro Resources}

The overall potential of hydropower development in the member economy is 75,000 MW. Many of Indonesia's rivers can generate up to $100 \mathrm{MW}$. Only $3.8 \%$ of this potential $(2,889 \mathrm{MW})$ is used at present (INA-N3). Still, there is an increase in hydropower use from 2.4 million BOE in 1969-1970 to nearly 26.2 million BOE in 1992-1992. Hydropower development is growing at $10.9 \%$ annually (INA-W1). 
Many micro-hydro units, having total installed capacity of about $5 \mathrm{MWp}$, are used in rural areas (INA-N3).

Table of References for Indonesia (see key following table for abbreviation and resource codes):

\begin{tabular}{|c|c|c|c|c|c|c|}
\hline Type of Analysis & Wind & Solar & Biomass & Geothermal & Hydro & General \\
\hline $\begin{array}{l}\text { Site-Specific } \\
\text { Analysis }\end{array}$ & & & & & & INA-N2 \\
\hline $\begin{array}{l}\text { Country-Wide } \\
\text { Surveys }\end{array}$ & & & & INA-G3 & SE-N3 & INA-N3 \\
\hline $\begin{array}{l}\text { Country-Wide } \\
\text { Maps }\end{array}$ & $\begin{array}{l}\text { INA-W1 } \\
\text { PRC-W10 }\end{array}$ & INA-S 1 & & INA-G3 & & \\
\hline \multicolumn{7}{|l|}{$\begin{array}{l}\text { Modeled Data } \\
\text { Sources }\end{array}$} \\
\hline $\begin{array}{l}\text { Measured Data } \\
\text { Sources }\end{array}$ & $\begin{array}{l}\text { INA-N1 } \\
\text { SE-N1 }\end{array}$ & $\begin{array}{l}\text { INA-S1 } \\
\text { SE-N1 }\end{array}$ & $\begin{array}{l}\text { INA-B1 } \\
\text { SE-N1 }\end{array}$ & $\begin{array}{c}\text { INA-G1 } \\
\text { INA-G3 } \\
\text { INA-N3 } \\
\text { SE-N1 } \\
\text { SE-N3 }\end{array}$ & SE-N3 & $\begin{array}{l}\text { INA-N3 } \\
\text { INA-W1 } \\
\text { SE-N3 }\end{array}$ \\
\hline $\begin{array}{l}\text { Technology or } \\
\text { Economic } \\
\text { Assessment Only }\end{array}$ & INA-W1 & SE-Nl & INA-B1 & $\begin{array}{l}\text { INA-G1 } \\
\text { INA-G2 }\end{array}$ & INA-W1 & $\begin{array}{l}\text { INA-N3 } \\
\text { INA-N2 } \\
\text { INA-W 1 } \\
\text { INA-N4 }\end{array}$ \\
\hline
\end{tabular}

Key:

$\underline{\text { Resources }}$

Abbreviations

Indonesia $=$ INA

South East Asia Region = SE

People's Republic of China $=$ PRC

Wind $=\mathrm{W}$

Solar $=\mathrm{S}$

Biomass $=\mathrm{B}$

Geothermal $=\mathrm{G}$

Hydro $=\mathrm{H}$

General $=$ N 


\section{Japan (JPN)}

\section{Overview of Japan's Energy Production}

The Japanese government officially plans to increase its share of new and renewable energy to $5.3 \%$ of the total by the year 2010 . This is approximately $34.6 \times 10^{6} \mathrm{kl}$ oil equivalent. Also, an additional $3.7 \%$ increase in hydro and $0.9 \%$ increase in geothermal energy is planned, so the total share of renewables will equal 9.9\% (JPN-N2).

\section{Wind Resources}

Japan is influenced by the Asian monsoon, and has good wind resources with high potential for wind energy use nationwide. High-pressure winds blow from Siberia, the Pacific Ocean, and the Okhotsk Ocean. Average annual wind speeds of $6 \mathrm{~m} / \mathrm{s}$ are common; at this speed, one wind turbine generator with a rated output of $300 \mathrm{~kW}$ can generate about $400,000 \mathrm{kWh} / \mathrm{yr}$. For sites with wind speeds of $10 \mathrm{~m} / \mathrm{s}$, the output can be 1.8 million $\mathrm{kWh} / \mathrm{yr}$ (JPN-W5). In 1995, the total capacity of wind power generation in Japan was about $10 \mathrm{MW}$ with 54 units (JPN-W10).

Wind velocities in the mountainous Mie Prefecture are higher than in the plains, particularly during December, January, and February, when wind power flux is 2.5 times higher than in June, July, and August. Average wind speeds in this region range from 1.5-3.4 m/s in June, July, and August to $2.7-4.6 \mathrm{~m} / \mathrm{s}$ in December, January, and February. The maximum instantaneous wind velocity is usually less than $40 \mathrm{~m} / \mathrm{s}$, except during typhoons (JPN-W4).

Promising conditions for wind power generation are also found at Muroto headland, Miyako Islands, and Nishihenna cape. Annual average wind speeds at these sites can be $8.5 \mathrm{~m} / \mathrm{s}$. The wind energy availability from one $250 \mathrm{~kW}$ wind turbine at a site with this wind resource is about $869 \mathrm{MWh}$, enough to provide power to 241 families. The turbulence intensity and the gust factor were the highest in the Miyako area at 0.17 and 1.50, respectively; the average wind velocity was $8 \mathrm{~m} / \mathrm{s}(\mathrm{JPN}-\mathrm{W} 2$, JPN- W8).

MITI/NEDO ${ }^{1}$ Miyako Project reached 2.7 MW capacity in 1995 with five wind turbine generators (WTGs). The capacity factor of 2 Meteorological Hydro Institute WTGs at Miyako is the highest in Japan with 53.2\%. The site also has the lowest cost of energy in Japan (11-12 $\mathrm{kWh}$ ), which is almost equivalent to conventional energy prices (JPN-W10). In Tohuku and Hokkaido, a mean annual wind velocity higher than $5 \mathrm{~m} / \mathrm{s}$ was observed at heights of 30-40 m above ground (JPN-W7). Tohuku Electric Power Company's Tappi Wind Park has reached 2.875 MW capacity with 10 WTGs, five of which were installed in September, October, November of 1995 (JPN-W10).

Wind turbine systems ranging in size from a few $\mathrm{kW}$ to $300 \mathrm{~kW}$ are commercially available. The total installed capacity is about $9 \mathrm{MW}$, but is expected to increase to $20 \mathrm{MW}$ by the year 2000 and to $150 \mathrm{MW}$ by 2010 (JPN-N4). NEDO plans to develop large, 500-kW wind turbines (JPN-N2).

1. The New Energy and Industrial Technology Development Organization carries out research and development of clean energy technologies and development of resources in Japan and overseas (JPN-G2) 


\section{Solar Resources}

Monthly mean global horizontal solar radiation values were computed for 153 stations between 1941 and 1971. In 1971, the Japan Meteorological Agency (JMA) began to replace its Robitzsch pyranometers with the Neo-type thermoelectric pyranometers. By 1975, 65 stations had completed the switch (JPN-S1).

The largest monthly mean percentage of possible sunshine $(\mathrm{n} / \mathrm{N})$ is 0.83 at Minamitorishima, recorded in October 1974; the smallest is 0.07 at Rumoi in December 1973 (JPN-S1).

From the data gathered at 153 stations mentioned above, the following formula is obtained (JPN-S5):

where:

$$
\mathrm{H} / \mathrm{H}_{\mathrm{o}}=0.149+0.546 \mathrm{n} / \mathrm{N}+0.037 \sinh +0.048 \mathrm{G}
$$

$\mathrm{h}$ is the monthly mean solar altitude at culmination, and

$G$ is the ratio of the number of days with a snow cover of $10 \mathrm{~cm}$ or more in a month to the number of days in the month.

The monthly minimum solar radiation occurs in December, with values of around 1.20 $\mathrm{kWhm}-{ }^{2}$ day- ${ }^{1}$. The maximum occurs in May at $4.78 \mathrm{kWhm}-{ }^{2}$ day ${ }^{1}$. The extreme maximum among individual stations at Kumejima in the Ryuku islands occurs in June at $6.1 \mathrm{kWhm}^{2}{ }^{2} \mathrm{day}_{-}{ }^{1}$. The variability of monthly solar radiation during the year is small in the Japan Sea, but large on the Pacific region, reflecting the December, January, and February monsoon. For the entire member economy, the annual mean is about $3.33 \mathrm{kWhm}-{ }^{2} \mathrm{day}-{ }^{1}$.

Reference JPN-S1 provides detailed maps of the global solar radiation distribution over Japan (JPN-S1). The typical overall maximum is $3.89 \mathrm{kWhm}^{-2}$ day- ${ }^{1}$ in Shionomisaki; the minimum is in Wakkanai at $2.86 \mathrm{kWhm}^{2}{ }^{2} \mathrm{day}^{-1}$. The spatial variability of solar resources over Japan is substantial because of the large range of latitudes, complex topography, and climate. Overall, Japan is considered to have abundant solar energy resources (JPN-S1, JPN-S2).

The three locations with the highest annual average global horizontal solar resource are (SE-S1):

\begin{tabular}{|l|c|}
\hline \multicolumn{1}{|c|}{ Location } & Yearly Average Radiation \\
\hline \hline Murotomisaki & $5.14 \mathrm{kWhm}^{2}{ }^{2}$ day- $^{1}$ \\
\hline Oki-Daito-Zima & $4.68 \mathrm{kWhm}^{2}{ }^{2}$ day- $^{1}$ \\
\hline Saigo & $4.60 \mathrm{kWhm}^{2}{ }^{2}$ day- $^{1}$ \\
\hline
\end{tabular}

The diffuse component of the global total radiation has also been estimated using the following (JPN- S5):

$$
\mathrm{H}_{\mathrm{d}} / \mathrm{H}=0.733-1.119 \mathrm{n} / \mathrm{N}+0.702(\mathrm{n} / \mathrm{N})^{2}+0.217 \mathrm{C}
$$

where $\mathrm{C}$ is the mean monthly cloud amount. 
PV power is considered a priority among new technologies. The total PV capacity in Japan is about $20 \mathrm{MW}$, which is expected to grow to $400 \mathrm{MW}$ by the year 2000 and to 4,600 by 2010 . The distribution of solar heating used is expected to be 3 million $\mathrm{kl}$ (oil equivalent) by 2000 and $5.5 \mathrm{kl}$ by 2010 (JPN-N4).

NEDO has been able to obtain a $15 \%$ conversion efficiency in solar cells, and is currently aiming toward an $18 \%$ efficiency. The organization intends to lower PV production cost to $1 / 7$ of the present cost, which would make it 20-30 yen/1 kWh (JPN-N2).

\section{Biomass Resources}

Biomass power from waste incineration is a major technology in the member economy. Two thousand incineration plants in Japan use waste as a source of electric power, but only $30 \%$ of all the waste is used for power generation. The energy contribution from waste is $500 \mathrm{MW}$ currently, and is expected to rise to 2,000 MW by the year 2000 (JPN-N4).

\section{Geothermal Resources}

The total capacity of geothermal plants at 14 sites in Japan is $445 \mathrm{MW}$ (JPN-N4, JPN-G7). This capacity is expected to increase to $600 \mathrm{MW}$ by the year 2000 and to $2,800 \mathrm{MW}$ by 2010 (JPN-N4). Five new plants with a total capacity of $108,000 \mathrm{~kW}$ are under construction (JPN-G7). Two new geothermal power plants, Simikawa $(50,000 \mathrm{~kW})$ and Yamagawa $(300,000 \mathrm{~kW})$, are in operation (JPN-G6). Two technologies are being emphasized: HDR and binary cycle power generation, which uses geothermal fluid of medium temperature of $150-200^{\circ} \mathrm{C}$ (JPN- N4). The major barrier to developing geothermal resources is that many sites are located within national parks where development is restricted.

The Geothermal Development Promotion Survey (JPN-G7) is undertaking three types of surveys:

- Survey A is an aerial survey of $100-300 \mathrm{~km}^{2}$ that verifies the presence of temperature zones in the subsurface.

- Survey B is a district survey of $50-70 \mathrm{~km}^{2}$ that verifies the presence of geothermal reservoirs.

- $\quad$ Survey $\mathrm{C}$ is a pre-feasibility study of $5-10 \mathrm{~km}^{2}$ in which production-size exploratory wells are drilled for conducting long-term production tests and estimating potential.

During 1995, survey A was conducted in two areas, survey B in three areas, and survey C in two areas. Surveys A and B have already been conducted at 39 sites, 24 of which were confirmed to have temperatures greater than $200^{\circ} \mathrm{C}$ in the drill holes (JPN-G7).

A Deep-Seated Geothermal Resources Survey (drilling a 4,000-m-class borehole) was launched by NEDO to facilitate practical use of deep-seated geothermal energy (JPN-G7). Exploration technologies include:

1. Technologies that use seismic waves:

- seismic topography

- VSP (using P-wave and S-wave seismic wave sources)

- $\quad$ seismic reflection method 
2. Technologies that use electromagnetic waves

3. Technologies that use micro-earthquakes.

Only steam or high temperature (above $200^{\circ} \mathrm{C}$ ) hot water are currently used for geothermal power generation. Other geothermal sources, including hot water and HDR under $200^{\circ} \mathrm{C}$, have not yet been used. However, NEDO supports down-hole pump development with prospects for a 10-MW plant (JPN-N2).

HDR geothermal energy production is considered to be an ideal method to expand the development of Japan's wealth of terrestrial heat resources by the Central Research Institute of the Electric Power Industry (CRIEPI). This method is comparable to hydroelectric energy (JPN-G3). HDR research is being conducted in the Hijiori district, Yamagata Prefecture (JPN-N2), and volcanic energy is being used at Kuju volcano in central Kyushu (JPN-G2).

Table of References for Japan (see key following table for abbreviation and resource codes):

\begin{tabular}{|c|c|c|c|c|c|c|}
\hline Type of Analysis & Wind & Solar & Biomass & Geothermal & Hydro & General \\
\hline $\begin{array}{l}\text { Site-Specific } \\
\text { Analysis }\end{array}$ & $\begin{array}{c}\text { JPN-W2 } \\
\text { JPN-W3 } \\
\text { JPN-W4 } \\
\text { JPN-W8 } \\
\text { JPN-W } \\
\text { JPN-W10 }\end{array}$ & & & JPN-G2 & & \\
\hline $\begin{array}{l}\text { Country-Wide } \\
\text { Surveys }\end{array}$ & JPN-W10 & & & JPN-G7 & & JPN-N4 \\
\hline Country-Wide Maps & $\begin{array}{l}\text { JPN-W7 } \\
\text { JPN-W10 } \\
\text { PRC-W10 }\end{array}$ & JPN-S5 & & & & \\
\hline $\begin{array}{l}\text { Modeled Data } \\
\text { Sources }\end{array}$ & & $\begin{array}{l}\text { JPN-S1 } \\
\text { JPN-S5 }\end{array}$ & & & & \\
\hline $\begin{array}{l}\text { Measured Data } \\
\text { Sources }\end{array}$ & $\begin{array}{l}\text { JPN-W2 } \\
\text { JPN-W4 } \\
\text { JPN-W5 } \\
\text { JPN-W8 }\end{array}$ & $\begin{array}{c}\text { JPN-S1 } \\
\text { JPN-S5 } \\
\text { JPN-N4 } \\
\text { SE-S1 }\end{array}$ & & $\begin{array}{l}\text { JPN-G7 } \\
\text { JPN-N4 }\end{array}$ & & \\
\hline $\begin{array}{l}\text { Technology or } \\
\text { Economic } \\
\text { Assessment Only }\end{array}$ & $\begin{array}{l}\text { JPN-W10 } \\
\text { JPN-N4 } \\
\text { JPN-N2 }\end{array}$ & $\begin{array}{l}\text { JPN-S1 } \\
\text { JPN-S2 } \\
\text { JPN-N4 } \\
\text { JPN-N2 }\end{array}$ & JPN-N4 & $\begin{array}{l}\text { JPN-G6 } \\
\text { JPN-N4 } \\
\text { JPN-G3 }\end{array}$ & & JPN-N2 \\
\hline
\end{tabular}

Key:

$\underline{\text { Abbreviations }}$

Japan = JPN

People's Republic of China $=$ PRC

South East Asia Region = SE $\underline{\text { Resources }}$

Wind $=\mathrm{W}$

Solar $=\mathrm{S}$

Biomass $=\mathrm{B}$

Geothermal $=\mathrm{G}$

Hydro $=\mathrm{H}$

General $=$ N 


\section{Republic of Korea (ROK)}

\section{Overview of Korea's Energy Production}

The Republic of Korea has a humid East Asian monsoonal climate. The mean temperature in December, January, and February is $-3.5^{\circ} \mathrm{C}$ in January in Seoul. The highest temperature is about $25^{\circ} \mathrm{C}$. During December, January, and February, continental high pressure air is brought to Korea by strong northeastern winds from Siberia. The June, July, and August monsoon, in turn, brings moisture from the ocean, resulting in heavy rainfall. Annual precipitation varies from $500 \mathrm{~mm}$ in the northeast to $1,400 \mathrm{~mm}$ along the southern coast. The islands of Chejudo and Ullungdo receive between 1,400 and 1,500 mm annually. The middle and upper parts of the basins of the Somjiang, Hangang, and Ch'ongch'ongang rivers are considered relatively heavy rainfall areas as well (ROK-N4).

Korea is expected to use 82 tonnes of coal by the year 2015. Most of this coal will be imported. To meet the soaring demand for energy, an additional $4 \mathrm{GW}$ of coal-fired capacity is planned (ROK-N2). Since the 1970s, there have been attempts to diversify into other energy sources, so that by 1993 the energy mix included nuclear power, oil, LNG, and hydroelectric power (ROK-N3), as well as coal. The economy is beginning to show signs of slowing down (ROK-N1, ROK-N2, and ROK-N3), but Korea still has an enormous dependency on oil.

The total energy consumption in Korea is expected to grow at $6.5 \%$ annually until the year 2000, and $4.5 \%$ between 2000 and 2030, reaching 554.5 Mtoe in 2030 (five times more than in 1992). Of the total projected energy increase between 1992 and 2030, 37\% will come from the increase in oil consumption. The $\mathrm{CO}_{2}$ emissions per capita were 1.72 tC in 1992, higher than the world's average but still lower than those of other developed economies (ROK-N6).

The member economy has programs to use renewable energy, such as solar, for electricity generation. Rapid commercialization and enlargement of domestic markets for PV energy is expected in the near future (ROK-S1). From 1988 through 1995, the financial investment for the alternative energy program was $\$ 107.25$ million total, of which $21.3 \%$ ( $\$ 22.8$ million) was spent on the PV program (ROK-S3). In Korea, approximately $25 \%$ of the total energy demand is supplied by non-commercial energy sources (SE-N1). The goal of the member economy is to supply at least $3 \%$ of total energy needs with renewable power by the year 2001 (ROK-N5).

\section{Wind Resources}

The Republic of Korea has favorable conditions for the use of wind energy, particularly along coastal areas and islands where diesel electrical plants are in operation (ROK-W1). The yearly average wind velocity ranges from $4.6 \mathrm{~m} / \mathrm{s}$ to $5.6 \mathrm{~m} / \mathrm{s}$ (SE-N1). By the year 2001, the commercialization of $300 \mathrm{~kW}$ wind turbine generators is planned (ROK-N5).

\section{Solar Resources}

Site-specific measurements of solar radiation in Gangneung (ROK-S2) show that the direct normal solar radiation reaches hourly levels as high as $1,110 \mathrm{~W} / \mathrm{m}^{2}$ in May. This month also shows the highest mean radiation of $5.7 \mathrm{kWh} / \mathrm{m}^{2}$ day.

A solar resource survey for southeast Asia shows that in June the amount of solar radiation in the member economy varies from 5.22 to $5.52 \mathrm{kWh} / \mathrm{m}^{2}$ day; and in December from 1.16 to $1.74 \mathrm{kWh} /$ $\mathrm{m}^{2}$ day (SE-N1). The locations with the highest mean annual global horizontal solar irradiation are as follows (SE-S1): 


\begin{tabular}{|l|c|}
\hline \multicolumn{1}{|c|}{ Location } & Yearly Average Radiation \\
\hline \hline Pusan & $4.70 \mathrm{kWhm}^{-}{ }^{2}$ day- $^{1}$ \\
\hline Taikyu & $4.70 \mathrm{kWhm}^{-}{ }^{2}$ day- $^{1}$ \\
\hline Kangnung & $4.07 \mathrm{kWhm}^{-}{ }^{2}$ day- $^{1}$ \\
\hline
\end{tabular}

In 1995 there were $866 \mathrm{PV}$ demonstration sites with $50.38 \mathrm{kWp}$ capacity. The total installed capacity of PV was 1.68 MW at the end of 1995, the PV market has increased 10 times since 1980. By the year 2000, total installed capacity will reach $52 \mathrm{MWp}$ (ROK-S3). Throughout the member economy, $1500 \mathrm{PV}$ sets for lighting and telephone gridding are operating (SE-N1). For the years 1997 through 2001, 5 MW of PV energy per year is planned (ROK-N5).

\section{Biomass Resources}

By the year 2001, development of generator facilities using landfill gas with $10 \mathrm{MW}$ capacity is expected to be completed (ROK-N5). The potential for biogas production in Korea is about 0.3 million $\mathrm{m}^{3}$. (SE-N1)

\section{Geothermal Resources}

A typical geothermal area with Mesozoic rocks is located in Yusung (ROK-G1). Hydrothermal temperature has exceeded $95^{\circ} \mathrm{C}$, and is planned to exceed $150^{\circ} \mathrm{C}$ by the year 2001 (ROK-N5). 
Table of References for the Republic of Korea (see key following table for abbreviation and resource codes):

\begin{tabular}{|c|c|c|c|c|c|c|}
\hline Type of Analysis & Wind & Solar & Biomass & Geothermal & Hydro & General \\
\hline $\begin{array}{l}\text { Site-Specific } \\
\text { Analysis }\end{array}$ & & & & ROK-G1 & & \\
\hline $\begin{array}{l}\text { Country-Wide } \\
\text { Surveys }\end{array}$ & & ROK-S3 & & & & ROK-N4 \\
\hline $\begin{array}{l}\text { Country-Wide } \\
\text { Maps }\end{array}$ & & & & & & \\
\hline $\begin{array}{l}\text { Modeled Data } \\
\text { Sources }\end{array}$ & & & & & & \\
\hline $\begin{array}{l}\text { Measured Data } \\
\text { Sources }\end{array}$ & SE-N1 & $\begin{array}{l}\text { ROK-S2 } \\
\text { SE-S1 } \\
\text { SE-N1 }\end{array}$ & SE-N1 & & & $\begin{array}{c}\text { ROK-N2 } \\
\text { ROK-N3 } \\
\text { ROK-N4 } \\
\text { SE-N1 }\end{array}$ \\
\hline $\begin{array}{l}\text { Technology or } \\
\text { Economic } \\
\text { Assessment Only }\end{array}$ & $\begin{array}{l}\text { ROK-W1 } \\
\text { ROK-N5 }\end{array}$ & ROK-N5 & ROK-N5 & ROK-N5 & & $\begin{array}{l}\text { ROK-N2 } \\
\text { ROK-N3 } \\
\text { ROK-N6 }\end{array}$ \\
\hline
\end{tabular}

Key:

$\underline{\text { Abbreviations }}$

Republic of Korea $=$ ROK

South East Asia Region = SE
Resources

Wind $=\mathrm{W}$

Solar $=\mathrm{S}$

Biomass $=\mathrm{B}$

Geothermal $=\mathrm{G}$

Hydro $=\mathrm{H}$

General $=$ N 


\section{Malaysia (MAS)}

\section{Overview of Malaysia's Energy Production}

In 1990, Malaysian primary supply of energy was distributed as follows (MAS-N1):

\begin{tabular}{|l|c|}
\hline \multicolumn{1}{|c|}{ Source of Energy } & ktoe \\
\hline \hline Crude oil & 8,609 \\
\hline Petroleum product & 2,352 \\
\hline Natural gas & 2,971 \\
\hline Hydropower & 504 \\
\hline Coal and coke & 564 \\
\hline Fuelwood & 1,864 \\
\hline Palm oil mill wastes (biomass) & 1,142 \\
\hline
\end{tabular}

The following table shows Malaysia's energy consumption levels compared with a few of its Asean neighbors (SE-N3):

\begin{tabular}{|l|c|}
\hline \multicolumn{1}{|c|}{ Country } & Per-Capita Energy Consumption (toe) \\
\hline \hline Brunei & 3.80 \\
\hline Indonesia & 0.23 \\
\hline Malaysia & 0.78 \\
\hline Philippines & 0.38 \\
\hline Singapore & 4.46 \\
\hline Thailand & 0.33 \\
\hline
\end{tabular}

The breakdown of Malaysia's energy resources is as follows (SE-N3): 


\begin{tabular}{|c|c|c|c|c|}
\hline $\begin{array}{c}\text { Oil } \\
\text { (billion bbl) }\end{array}$ & $\begin{array}{c}\text { Gas } \\
\text { (trillion } \mathrm{m}^{3} \text { ) }\end{array}$ & $\begin{array}{c}\text { Coal } \\
\text { (billion tonnes) }\end{array}$ & $\begin{array}{c}\text { Hydro } \\
\text { MW }\end{array}$ & $\begin{array}{c}\text { Geothermal } \\
\text { MW }\end{array}$ \\
\hline \hline 3,100 & 52,000 & $\begin{array}{c}\text { Bituminous: } 300 \\
\text { Lignite: } 120\end{array}$ & 25,000 & -- \\
\hline
\end{tabular}

The following table shows the remaining recoverable reserves (MAS-N1):

\begin{tabular}{|c|c|c|c|c|}
\hline Region & $\begin{array}{c}\text { Oil } \\
\text { (billion bbl) }\end{array}$ & $\begin{array}{c}\text { Gas } \\
\left(\text { trillion } \mathrm{ft}^{3}\right)\end{array}$ & $\begin{array}{l}\text { Hydro } \\
\text { (MW) }\end{array}$ & $\begin{array}{l}\text { Coal } \\
\text { (million } \\
\text { tonnes) }\end{array}$ \\
\hline Peninsular Malaysia & 1.46 & 26.43 & 4,000 & 22.1 \\
\hline Sarawak & 1.01 & 23.62 & 20,000 & 732.3 \\
\hline Sabah & 0.58 & 2.40 & 5,000 & -- \\
\hline Total & 3.05 & 52.45 & 29,000 & 771.7 \\
\hline
\end{tabular}

Malaysia's non-commercial energy supply is less than $25 \%$ of the total energy supply (SE-N1).

\section{Wind Resources}

A survey of the wind energy potential at 10 measurement sites has been published (MAS-W2). This report shows that, with the exception of the northeast monsoon seasons, when wind speeds reach $5-10 \mathrm{~m} / \mathrm{s}$, the measured wind resource is relatively light on the east coast and in peninsular Malaysia (MAS-W2). Wind speeds typically reach the maximum in the afternoon, and the minimum just before sunrise. Wind directions are persistent at the stations in Kuala Terengganu (where wind density is high), Alor Setar, Petaling Jaya, and Melaka. At the Cameron Highland station, the wind directions are less persistent. In Sabah, at the stations at Kota Kinabalu and Tawau, the winds are stable and consistent, but the mean in Tawau is lower. In the Sarawak region, at Kuching station, wind directions are not persistent at the beginning and the end of the year. Overall, Mersing and Kuala Terengganu are considered to have the greatest wind potential in Malaysia, due to the northeast monsoon.

The highest mean wind speed in peninsular Malaysia is in Mersing (MAS-W2). It is high at the beginning and the end of the year $(4-5.5 \mathrm{~m} / \mathrm{s})$ and low $(2.6 \mathrm{~m} / \mathrm{s})$ during the remaining period. The annual mean wind power density for Mersing is $85.61 \mathrm{~W} / \mathrm{m}^{2}$, but in January it rises to $119.7 \mathrm{~W} / \mathrm{m}^{2}$ due to the northeastern monsoon. The opposite is true of Kota Kinabalu: low wind speeds $(2 \mathrm{~m} / \mathrm{s})$ are observed from December to March; higher speeds of $3 \mathrm{~m} / \mathrm{s}^{\#}$ occur from May to November.

Seasonal mean wind power densities at the surface exceed $20 \mathrm{~W} / \mathrm{m}^{2}$ at stations on the east coast and in the southern part of western Malaysia from November to March during the northeastern monsoon. At $600 \mathrm{~m}$ above the surface, estimates of seasonal wind power densities range from 
$100 \mathrm{~W} / \mathrm{m}^{2}$ to more than $300 \mathrm{~W} / \mathrm{m}^{2}$, the highest being over the southern part of western Malaysia and over the east coast of eastern and western Malaysia, also during the northeast monsoon (MAS-W l).

\section{Solar Resources}

In peninsular Malaysia, tropical climates predominate (MAS-S1). Cloudy conditions and rain are brought by the southern monsoon from June to early October, and by the northeastern monsoon from November to March. Thus, the west coast is dry from November to March, and the east coast is dry from June to September. During these dry seasons there is only occasional convection-type rainfall in the late afternoon. The average temperature throughout the year is $20^{\circ} \mathrm{C}$; the diurnal temperature range is approximately $7^{\circ} \mathrm{C}$. Peninsular Malaysia receives less rain than Sabah and Sarawak; nevertheless, most of peninsular Malaysia has more than 170 rainy days a year (MAS-S4).

The Bangi region (MAS-S3) is influenced by the same monsoons as the rest of peninsular Malaysia. There are two particularly wet regions with total rainfall of more than $275 \mathrm{~cm} / \mathrm{yr}$ and more than 170 rainy days. One stretches along the entire eastern part, with heavy rainfall in November and December. The other covers half of the western side of the peninsula, with heavy rainfall in October and November. The relative humidity for this region is around $82-88 \%$; never falling below $60 \%$, and often rising to $90 \%$ in highland areas.

Solar radiation varies throughout this region. On average, however, $51 \%$ of days are partly cloudy, $16 \%$ are clear, $14 \%$ are rainy, $17 \%$ have afternoon rains, and $3 \%$ of days have a rare phenomenon, when instantaneous solar radiation intensity rises higher than the solar constant. An example of such a day can have a maximum solar intensity of $1400 \mathrm{~W} / \mathrm{m}^{2}$ and a daily total solar radiation of around $4.16 \mathrm{kWhr} / \mathrm{m}^{2}$. Such a resource characteristic can actually damage a PV system's DC/AC inverter and power controller.

Partly cloudy weather conditions are a familiar pattern for Bangi; maximum solar intensity is about $1142.9 \mathrm{~W} / \mathrm{m}^{2}$ and annual average daily total solar radiation is $4.43 \mathrm{kWhr} / \mathrm{m}^{2}$. Also common are the days with afternoon rain. Maximum solar intensity on such days can still reach $957 \mathrm{~W} / \mathrm{m}^{2}$, yet daily total solar radiation is around $3 \mathrm{kWh} / \mathrm{m}^{2}$. Clear days, when maximum solar intensity reaches $971 \mathrm{~W} / \mathrm{m}^{2}$ and daily total solar radiation is as high as $6.957 \mathrm{kWh} / \mathrm{m}^{2}$, are rare, as are cloudy days, when the maximum intensity is $121.4 \mathrm{~W} / \mathrm{m}^{2}$ and the daily total solar radiation is 0.50 $\mathrm{kWh} / \mathrm{m}^{2}$. Overall, the solar resource in this region is relatively high year round, averaging 6 hours per day of direct sunshine, with the highest resource occurring in July.

Solar radiation estimates using the Angstrom relationship (equation 1) are available for the 4-year period from 1975 to 1978 for three stations in peninsular Malaysia. The following table shows the maximum and average annual values of solar radiation (MAS-S1) and annual average temperature (MAS-S2) for these stations: 


\begin{tabular}{|l|l|c|c|c|c|}
\hline \multicolumn{1}{|c|}{ Location } & $\begin{array}{c}\text { Highest } \\
\left(\mathrm{kWh} / \mathrm{m}^{2} \text { day) }\right.\end{array}$ & $\begin{array}{c}\text { Annual } \\
\text { Average } \\
\left(\mathrm{kWh} / \mathrm{m}^{2} \text { day }\right)\end{array}$ & $\begin{array}{c}\text { Highest } \\
\text { sunshine } \\
\text { hours }\end{array}$ & $\begin{array}{c}\text { Annual } \\
\text { Average } \\
\text { sunshine } \\
\text { hours }\end{array}$ & $\begin{array}{c}\text { Mean Annual } \\
\text { Temperature }\left({ }^{\circ} \mathrm{C}\right)\end{array}$ \\
\hline \hline Kuala Lumpur & 5.09 (March) & 4.60 & 6.7 (April) & 6.02 & 26.4 \\
\hline Penang & $\begin{array}{l}5.86 \text { (January } \\
\text { and March) }\end{array}$ & 5.21 & 8.65 (January) & 6.71 & 26.9 \\
\hline Kota Bahru & 5.93 (April) & 4.82 & 9.29 (April) & 7.04 & 26.7 \\
\hline
\end{tabular}

Reference MAS-S1 also notes that the location with the highest annual average solar resource is Alor Setar with $5.23 \mathrm{kWh} / \mathrm{m}^{2}$ day. However, the sunshine duration at this station averages only 6.85 hours/day, less than at other locations.

Days with low daily total solar radiation are rare in Penang and Kuala Lumpur. In Penang, however, days with high radiation occur more frequently than in Kuala Lumpur. In Kota Bahru, there is relatively large variability of daily total solar radiation. Days with extremely low radiation are frequent during the northeastern monsoon season; high radiation is common during the dry season for this region (MAS-S2). In Kuala Lumpur, intensity can reach approximately $625 \mathrm{Wh} / \mathrm{m}^{2}$ at noon MAS-S5).

A major difficulty with use of equation (1) for solar estimates in Malaysia is that the regression coefficients $a$ and $b$ vary depending on rainfall (MAS-S4). Thus, new estimates for solar resources throughout Malaysia have been developed with an adjustment for rainfall; these estimates are shown in the following table, where $\mathrm{H} / \mathrm{H}_{0}$ represents the ratio of the estimated to the total possible monthly average daily total:

\begin{tabular}{|l|c|c|}
\hline \multicolumn{1}{|c|}{ Location } & Maximum $\mathrm{H} / \mathrm{H}_{0}$ & Month of the Year \\
\hline \hline Petaling Jaya & 0.4850 & February \\
\hline Kuala Lumpur & 0.4824 & February \\
\hline Bayon Lepas & 0.5876 & January \\
\hline Senai & 0.4733 & April \\
\hline Kota Bahru & 0.5384 & April \\
\hline Kota Kinabalu & 0.5905 & April \\
\hline Kuching & 0.4770 & June \\
\hline
\end{tabular}

Other studies (SE-N1) show that Malaysia's solar radiation in June ranges from 4.64 to $5.22 \mathrm{kWh} /$ $\mathrm{m}^{2}$ day, and in December from 4.06 to $4.64 \mathrm{kWh} / \mathrm{m}^{2}$ day.

The locations with highest global horizontal radiation are as follows (SE-S1): 


\begin{tabular}{|c|c|}
\hline Location & Yearly Average Radiation \\
\hline Alor Setar & $6.08 \mathrm{kWhm}-{ }^{2} \mathrm{day}-{ }^{1}$ \\
\hline Penang & $6.06 \mathrm{kWhm}^{2}{ }^{2}$ day- $^{1}$ \\
\hline Ipoh & $5.94 \mathrm{kWhm}-{ }^{2}$ day- ${ }^{1}$ \\
\hline
\end{tabular}

In order to calculate the diffuse component of global radiation, equation (1) can be used, since in complete absence of sunlight, $\mathrm{n}$ is 0 . Then:

$$
\mathrm{H}=\mathrm{aH}_{\mathrm{m}}
$$

The monthly means of daily solar radiation range from $4.80 \mathrm{kWh} / \mathrm{m}^{2}$ day in the states of Perlis, Kedah, Pulan Pinang, and Northern Perak to about $3.00 \mathrm{kWh} / \mathrm{m}^{2}$ day on the east coast, with Langkawi having the highest and Kauntan the lowest. Measured solar radiation data from more than 10 years is available only for Penang and Kuala Lumpur. In Penang, the diffuse component of global total radiation is so high, that direct solar radiation is less than $60 \%$ of the total. This may cause a reduction in performance of conventional collector systems that use concentrators. Variability is fairly high in the east coast, but most days have high solar radiation in the west coast. The days without sunshine are virtually nonexistent in Malaysia (MAS-N1).

The solar resource characteristics in peninsular Malaysia allow for the operation of various applications of solar technologies, such as drying for agricultural production and hot water heating (MAS-S1, MAS-S4).

\section{Biomass Resources}

\section{Palm oil industry}

About 2.1 million ha in Malaysia are used for harvesting palm oil. In 1992, 6.37 million tonnes of crude palm oil were extracted from a total of 31 million tonnes of fresh fruit bunch (FFB). The remainder was generated as bio-waste and has contributed substantially to the nation's energy supply. Fiber and shell contribute 217 million liters of diesel equivalent; empty fruit bunch contributes 112 million liters of diesel equivalent; biogas from oil effluent contributes 289 million liters of diesel equivalent. The total biomass supply from this industry was approximately 618 million liters of diesel equivalent (MAS-N1).

\section{Other biomass}

Some $79 \%$ of Malaysian land is under forestry and agriculture, which produce large amounts of processing residues that can be used to generate electricity. Forestry practices produce $13,581,000 \mathrm{~m}^{3}$ of residue, and agricultural practices produce $14,730,000 \mathrm{~m}^{3}$ of residue, for a total of $28,311,000 \mathrm{~m}^{3}$ (MAS-N1).

The forestry industry is subdivided into three regions: Peninsular Malaysia, Sarawak, and Sabah. Each region has its own specific characteristics (INA-B1): 
- Peninsular Malaysia: 6.3 million ha is natural forest. Its production capacity is estimated at $77 \mathrm{~m}^{3} /$ ha over a 50 -year cycle in logged areas, and $60 \mathrm{~m}^{3} / \mathrm{ha}$ in better managed areas. In 1984 , roundwood production in this area amounted to $9.4 \mathrm{~m}^{3} / \mathrm{ha}$.

- Sarawak's forestry area covers 9.4 million ha. In 1980 it yielded 8 million $\mathrm{m}^{3} / \mathrm{ha}$ of roundwood.

- Sabah has 4.7 million ha under forest. During the past decade, 8 to 10 million $\mathrm{m}^{3}$ of logs were removed from this area.

About $50 \%$ of the total species are considered production forest. More than $80 \%$ belong to the Dipterocarp (meranti) group (INA-B1).

Malaysia also has 2 million $\mathrm{m}^{3}$ of biogas production potential (SE-N1).

\section{Hydro Resources}

Most of Malaysia's vast hydropower resources remain unexploited. In peninsular Malaysia, all the hydro projects, operating and under construction, have an average annual output of 5,200 GWh. In Sabah and Sarawak, the generation potential is very large. In Sarawak the annual output is estimated at 65,000 GWh, and the estimates in Sabah are 41,000 Even though the present demand does not require intensive development of hydropower, the growing energy consumption in the member economy will soon change the situation (MAS-H1).

The following prospects might substantially increase Malaysia's hydroelectric energy capacity (MAS- H1):

- There may be a possibility to link peninsular Malaysia and Sarawak across $650 \mathrm{~km}$ of the South China Sea using a high-voltage submarine cable. To supply the power for the link, the Bakun hydro project with 2,400 MW capacity is proposed on Sarawak's Rajang river. Such a project, though, will not only require $\$ 8.7$ billion (U.S.) to be raised through the private sector, but will also require that more than 80,000 ha of forest be cleared and 5,000 inhabitants displaced.

- A smaller (900 MW) project is under study at Marum in Sarawak. This facility would supply power to locations on Borneo island and would not depend on an undersea cable. Transmission links to Sabah, Brunei, and Indonesia are being considered.

- With other possible locations, such as Pelagus and Baleh (with $770 \mathrm{MW}$ and $950 \mathrm{MW}$ capacity respectively), these projects could amount to an additional 5,020 MW generating capacity. The completion of the two projects, Bakun and Marum, would provide $31 \%$ of peninsular Malaysia's power supply, 99\% of Sabah's, and 87\% of Sarawak's.

- Sabah's electricity board is launching a major hydropower storage project at Liwagu with 164 MW, which would supply power to Sandakan and Kota Kinabalu.

- Potential storage projects in the state of Kelentan are Neggiri (450 MW), Lebir (272 MW) and Galas (108 MW). Also, an 82-MW run-of-river unit can be installed downstream from the storage projects. The Pahang River basin in the state of Pahang has an enormous, largely undeveloped, potential for more than $3,200 \mathrm{GWH} /$ year.

These projects could substantially increase Malaysia's hydroelectricity generation, but they present heavy environmental costs (MAS-H1). 
During the past decade, there has been a threefold increase in hydro electricity generation. The present capacity is $29,000 \mathrm{MW}$, and energy output is about $123 \mathrm{TWh} / \mathrm{yr}$. This output is large enough to provide for the present electricity needs as well as for future years. However, there is an uneven distribution in hydro power supply: $86 \%$ is located in Sabah and Sarawak, and only $14 \%$ in peninsular Malaysia where most of its population (83\%) lives (MAS-N1).

Table of References for Malaysia (see key following table for abbreviation and resource codes):

\begin{tabular}{|c|c|c|c|c|c|c|}
\hline Type of Analysis & Wind & Solar & Biomass & Geothermal & Hydro & General \\
\hline $\begin{array}{l}\text { Site-Specific } \\
\text { Analysis }\end{array}$ & MAS-W2 & $\begin{array}{l}\text { MAS-S3 } \\
\text { MAS-S4 }\end{array}$ & & & MAS-H1 & \\
\hline $\begin{array}{l}\text { Country-Wide } \\
\text { Surveys }\end{array}$ & MAS-W2 & & $\begin{array}{l}\text { MAS-N1 } \\
\text { INA-B1 }\end{array}$ & & MAS-H1 & \\
\hline $\begin{array}{l}\text { Country-Wide } \\
\text { Maps }\end{array}$ & & & & & MAS-H1 & \\
\hline $\begin{array}{l}\text { Modeled Data } \\
\text { Sources }\end{array}$ & MAS-W2 & $\begin{array}{l}\text { MAS-S1 } \\
\text { MAS-S4 } \\
\text { MAS-S5 }\end{array}$ & & & & \\
\hline $\begin{array}{l}\text { Measured Data } \\
\text { Sources }\end{array}$ & $\begin{array}{l}\text { MAS-W1 } \\
\text { MAS-W2 } \\
\text { SE-N1 }\end{array}$ & $\begin{array}{c}\text { MAS-S1 } \\
\text { MAS-S2 } \\
\text { MAS-S3 } \\
\text { MAS-S4 } \\
\text { MAS-S5 } \\
\text { MAS-S6 } \\
\text { MAS-N1 } \\
\text { SE-N1 } \\
\text { SE-S1 }\end{array}$ & $\begin{array}{l}\text { SE-N1 } \\
\text { INA-B1 }\end{array}$ & & $\begin{array}{l}\text { MAS-N1 } \\
\text { MAS-H1 } \\
\text { SE-N3 }\end{array}$ & $\begin{array}{c}\text { SE-N1 } \\
\text { SE-N3 } \\
\text { MAS-N1 }\end{array}$ \\
\hline $\begin{array}{l}\text { Technology or } \\
\text { Economic } \\
\text { Assessment Only }\end{array}$ & & MAS-N1 & & & $\begin{array}{l}\text { MAS-H1 } \\
\text { MAS-N1 }\end{array}$ & \\
\hline
\end{tabular}

Key:

$\underline{\text { Abbreviations }}$

Malaysia $=$ MAS

Indonesia $=$ INA

South East Asia Region = SE $\underline{\text { Resources }}$

Wind $=\mathrm{W}$

Solar $=\mathrm{S}$

Biomass $=\mathrm{B}$

Geothermal $=\mathrm{G}$

Hydro $=\mathrm{H}$

General $=$ N 


\section{Mexico (MEX)}

\section{Overview of Mexico's Energy Production}

The demand for electricity in this member economy has increased dramatically during the past decade and is expected to keep growing, as the following table demonstrates (MEX-N1):

\begin{tabular}{|l|c|c|c|}
\hline \multirow{2}{*}{} & \multicolumn{3}{|c|}{ Electricity Generation in Mexico } \\
\cline { 2 - 4 } & 1980 & 1987 & 2025 \\
\hline \hline Total (Peta-Joules) & 2.43 & 347 & 1334 \\
\hline Coal & $0 \%$ & $8 \%$ & $25 \%$ \\
\hline Oil & $52 \%$ & $61 \%$ & $53 \%$ \\
\hline Natural Gas & $14 \%$ & $8 \%$ & $2 \%$ \\
\hline Nuclear and Geothermal & $1 \%$ & $4 \%$ & $8 \%$ \\
\hline Hydro & $33 \%$ & $19 \%$ & $12 \%$ \\
\hline
\end{tabular}

As this table shows, a large change has taken place since 1980. The use of oil increased dramatically, but later leveled off; the use of coal continues to rise at significant rates, and the use of hydropower and natural gas is decreasing. Mexico is one of the largest hydrocarbon producers and exporters in the world (MEX-N3).

\section{Wind Resources}

There is a good potential for wind energy in Mexico, but it remains mostly underdeveloped. The estimated potential for total installed capacity for wind electricity generation is approximately 5 GW (MEX-N3). Currently, wind is used primarily for off-grid applications (MEX-N1), such as for water pumping in the Yucatan peninsula and Baja California (MEX-N3). However, two new projects, a 25-unit totaling $2 \mathrm{MW}$ owned by the City of Zacatecas, and a seven-unit totalling 1.5 MW, are being developed to be interconnected to the grid (MEX-N3).

Recently, NREL conducted a wind resource assessment for Mexico by examining data from 186 wind measurement locations operated by the member economy's national weather service (MEXW1). This study revealed that many of the stations exhibited decreasing wind speeds over time (beginning in the early 1970s), which can be attributed to degradation and lack of calibration of the equipment and obstructions to the wind flow measured by the equipment. For example, the Mexicali station showed a steady downward trend of wind speed from $5 \mathrm{~m} / \mathrm{s}$ in 1974-1975 (with a wind power density of $170 \mathrm{~W} / \mathrm{m}^{2}$ ), to $1.5 \mathrm{~m} / \mathrm{s}$ in $1990-1991$ (with density of $25 \mathrm{~W} / \mathrm{m}^{2}$ ), as shown in the following table: 


\begin{tabular}{|c|c|c|c|}
\hline Period & Wind Speed $(\mathrm{m} / \mathrm{s})$ & Power $\left(\mathrm{W} / \mathrm{m}^{2}\right)$ & Calm $(\%)$ \\
\hline \hline $1973-1975$ & 5.2 & 170 & 7 \\
\hline $1986-1991$ & 1.5 & 20 & 62 \\
\hline
\end{tabular}

The most probable cause of this discrepancy is the fact that this site is becoming less exposed or the anemometer is degrading with time. Thus, it was concluded that the more representative wind speeds to use in this wind resource assessment are those obtained from the early $1970 \mathrm{~s}^{1}$.

The following tables show the results of NREL's analysis of average wind power densities (W/ $\mathrm{m}^{2}$ ) at $10 \mathrm{~m}$ height for four major regions in Mexico.

\begin{tabular}{|c|c|c|c|c|c|}
\hline \multicolumn{3}{|c|}{ Yucatan Peninsula } & \multicolumn{3}{c|}{ Northern Gulf Plain } \\
\hline Merida & Campeche & Chetumal & Tampico & Cuidad Victoria/ & Matamoros \\
\hline \hline 165 & 120 & 205 & 205 & 170 & 165 \\
\hline
\end{tabular}

\begin{tabular}{|c|c|c|c|c|c|}
\hline \multicolumn{3}{|c|}{ Central Highlands } & \multicolumn{3}{c|}{ Northeast } \\
\hline Durango & San Luis Potosi & Zacatecas & Chihuahua & Hermosillo & La Paz \\
\hline \hline 140 & 155 & 270 & 120 & 80 & 85 \\
\hline
\end{tabular}

Once the wind data has been adjusted to representative values, and consideration has been made of local topographic and shoreline influences on the wind resource, maps of wind resources were developed for grid-connected and small turbine applications. These maps show that more areas are suitable for rural wind power applications than for utility-scale applications, since smaller wind turbines can operate more economically at lower wind speeds. These maps also show that the best wind resources are found in the southern part of the Isthmus of Tehuantepec and in the central highlands in proximity to Zacatecas.

\section{Solar Resources}

A number of solar atlases have been prepared for Mexico (MEX-S1 through MEX-S3, and S5). These atlases generally make use of sunshine hour records, since there are very few actual long-term solar measurement stations in Mexico (although recently a network of about 65 highquality measurement stations has been installed in conjunction with national weather service stations). These atlases report the monthly average daily total solar resource for numerous surface stations, or present maps of isolines of solar resources monthly and annually. In addition, some

1. Although similar assessments have not been completed for other member economies, preliminary studies for wind assessments in Indonesia, the Philippines, PRC, and Thailand indicate that similar phenomena of degrading wind speed measurements over time can be found at many national weather service stations. 
approaches (such as MEX-S6) use satellite imagery to develop estimates of solar resources. The differences among the studies are as much as 15\%; nevertheless, this represents typical uncertainties in estimating solar resources from "proxy" data sets.

Based on SE-S1, the locations with the highest global horizontal solar radiation are as follows:

\begin{tabular}{|l|c|}
\hline \multicolumn{1}{|c|}{ Location } & Yearly Average Radiation \\
\hline \hline Veracruz & $5.72 \mathrm{kWhm}-{ }^{2}{ }^{2}{ }^{2}-{ }^{2}$ \\
\hline Altozomoni & $5.62 \mathrm{kWhm}-{ }^{2}$ day- $^{2}$ \\
\hline Hermozillo & $5.40 \mathrm{kWhm}-{ }^{2}$ day- $^{2}$ \\
\hline
\end{tabular}

The following table is an example of the monthly average daily total solar resource estimates (in this case, at $19^{\circ} \mathrm{N}, 99^{\circ} \mathrm{W}$ ) that can be obtained from satellite imagery (MEX-S6):

\begin{tabular}{|l|c|c|}
\hline \multicolumn{1}{|c|}{ Month } & $\begin{array}{c}\text { Radiation } \\
\left(\mathrm{MJ} / \mathrm{m}^{2}\right)\end{array}$ & $\begin{array}{c}\text { Radiation } \\
\left(\mathrm{kWh} / \mathrm{m}^{2}\right)^{*}\end{array}$ \\
\hline \hline January & 13.79 & 3.83 \\
\hline February & 17.51 & 4.86 \\
\hline March & 21.81 & 6.06 \\
\hline April & 24.40 & 6.78 \\
\hline May & 22.44 & 6.23 \\
\hline June & 20.74 & 5.76 \\
\hline July & 16.78 & 4.66 \\
\hline August & 18.00 & 5.00 \\
\hline September & 14.86 & 4.13 \\
\hline October & 17.76 & 4.93 \\
\hline November & 14.73 & 4.09 \\
\hline December & 15.36 & 4.27 \\
\hline
\end{tabular}

According to MEX-S4, the highest solar intensity occurs from September to March in the central region of the member economy; from May to July the highest intensities are in the northern part. During April, solar intensities are evenly distributed throughout the country. Overall, the states of Chihuahua, Coahuila, Durango, Zacatecas, and San Luis Potosi receive the highest solar resource 
for University Station, Mexico City. The following table shows the effect of seasonality on solar radiation (MEX-S5):

\begin{tabular}{|c|c|c|}
\hline Period & $\begin{array}{c}\text { Global } \\
\left(\mathrm{kWh} / \mathrm{m}^{2}\right)\end{array}$ & $\begin{array}{c}\text { Diffuse } \\
\left(\mathrm{kWh} / \mathrm{m}^{2}\right)\end{array}$ \\
\hline \hline Cloudless day (01/08/87) & 4.67 & 0.944 \\
\hline Cloudy day (07/30/87 & 3.25 & 2.17 \\
\hline
\end{tabular}

The aforementioned reference (MEX-S5) also produced a solar climate study for Mexico City. This study shows that there is a decrease in the monthly variation of global solar radiation, when afternoon clouds absorb part of the incoming radiation during the wet season, which lasts from May to October. Convective clouds and higher water vapor content in the atmosphere cause an increase in the diffuse component of global total solar radiation, sometimes twice as high as during the November-April dry season. In the wet season, in the morning the diffuse is typically $36 \%$ of global, and in the afternoon it is $44 \%$. During the dry season the diffuse component is lower (27\% in the morning and 35\% in the afternoon). On a clear day, the amount of global solar energy received in the morning may be smaller than in the afternoon because various pollutants, concentrated in the stable lower layer of atmosphere, absorb and scatter the incident radiation. Nevertheless, the hourly values of diffuse radiation in the afternoon show an increase versus the morning hours: $8 \%$ during the seasonal mean and up to $12 \%$ on some days. During August, diffuse radiation values are more than $20 \%$ higher than during the cool season.

\section{Components of the Solar Resource in Mexico}

From the reference MEX-S7, the following can be concluded regarding the various components of the solar resource:

Daily total global horizontal irradiation

- Northwestern region that covers the states of Sohora and Chihuahua receives the most global irradiation throughout the year. The minimum occurs December through January, averaging approximately $3.75 \mathrm{kWh} / \mathrm{m}^{2}$, and the maximum occurs May through June, averaging more than $8.34 \mathrm{kWh} / \mathrm{m}^{2}$.

- $\quad$ Southwestern region of Oaxaca has uniform radiation values that vary from 5 to 6.12 $\mathrm{kWh} / \mathrm{m}^{2}$ throughout the year.

Daily total direct normal irradiation

- $\quad$ Northwestern region has a minimum of $5.56 \mathrm{kWh} / \mathrm{m}^{2}$ from December through January. During the months without rain, the maximum reaches nearly $8.34 \mathrm{kWh} / \mathrm{m}^{2}$.

- Southwestern region of Oaxaca receives over $5.56 \mathrm{kWh} / \mathrm{m}^{2}$ from October to April, reaching $7.78 \mathrm{kWh} / \mathrm{m}^{2}$ in February.

- The states of Durango and Zacatecas receive from 7.78 to $8.34 \mathrm{kWh} / \mathrm{m}^{2}$ from February through May. 
- From June to October, there is a variation from $2.78 \mathrm{kWh} / \mathrm{m}^{2}$ in the south central region to $7.78 \mathrm{kWh} / \mathrm{m}^{2}$ further to the north.

- From October on, the central region receives up to $6.11 \mathrm{kWh} / \mathrm{m}^{2}$, but both coastal regions receive less than $3.89 \mathrm{~kW} / \mathrm{m}^{2}$, with minimums of $1.67 \mathrm{kWh} / \mathrm{m}^{2}$.

Daily diffuse radiation

- $\quad$ Few variations were observed in diffuse radiation in the southeast region, with a minimum of $1.67 \mathrm{kWh} / \mathrm{m}^{2}$ and a maximum of $2.22 \mathrm{kWh} / \mathrm{m}^{2}$.

- The northeast region has an average of $2.50 \mathrm{kWh} / \mathrm{m}^{2}$.

In general, the regions of highest radiation in Mexico are the states of Sonora and Chihuahua and the eastern part of Baja California peninsula. These regions are, therefore, the most appropriate for installation of the systems that require a high incidence of solar radiation. The two regions with less than $5.27 \mathrm{kWh} / \mathrm{m}^{2}$ are Durango, Zacatecas, Aguascalientes, most of Pueblo, Cuerrero, and Oaxaca.

Nearly $172,500 \mathrm{~m}^{2}$ flat plate solar thermal systems were installed in Mexico by 1992 . In Tuzandepet, Veracruz, there is a pilot solar pond of $3,000 \mathrm{~m}^{2}$, which uses a $10-\mathrm{kW}$ capacity Rankine cycle engine, and is able to provide maximum temperature of $68^{\circ} \mathrm{C}$. In the mid-1980s, many private-sector companies and organizations contributed large sums of money for PV system installation for lighting, water pumping, and radios in the rural areas. Total installed PV system power amounted to approximately 7.4 MWp by 1994.

\section{Biomass Resources}

Biomass comprises $10 \%$ of total energy consumption in the member economy. In 1992, biomass consumption was $9 \times 10^{16}$ calories (MEX-N1). The main sources are sugar cane bagasse and fuelwood (MEX-N3). In 1990, Mexico had about $3 \mathrm{GW}$ installed of industrial generation capacity, with an additional $1 \mathrm{GW}$ capacity expected to be installed by the year 2000 (MEX-N1).

In rural Mexico firewood is the most important source of energy, and it is largely non-commercial (MEX-N2). Some 70\% of the 17 million total, i.e. 11.9 million, is used for food processing. However, since Mexico is the world's eighth largest sugar-producing nation, sugar cane bagasse can contribute substantially to electricity generation; about $230 \mathrm{~kW}$ of electricity can be sold for each ton of cane milled. Given the potential growth of the sugar industry, approximately 13,400 GWh of electricity could be sold to the grid if the mills adopt bagasse cogeneration techniques. The use of direct biomass combustors or biomass cogeneration systems are ranked high with respect to social acceptance in Mexico. Of course, accessibility of the biomass resource will determine its use (MEX-N1).

\section{Geothermal Resources}

Total geothermal electric capacity in the member economy was 753 MWe in 1994. In 1993, the electric generation from three active geothermal fields was $5876 \mathrm{GWh}$, or about $4.7 \%$ of total electricity generation, which places Mexico third worldwide in geothermal capacity and second in geothermal electric generation (MEX-G1). However, as of now only $29 \%$ of the estimated 
potential 2.4 GW is being used (MEX-N1). By the year 2000, this potential is expected to be completely exploited.

Mexico's main geothermal plant is "Cerro Prieto," near Mexicali. It has $620 \mathrm{MW}$ of installed capacity with its 150 deep wells. There are plans to install $200 \mathrm{MW}$ more in the near future. The second largest geothermal plant is "Los Azufrez" in Michoacan, which had 98 MW of installed capacity in 1994, with 40 MW of additional capacity planned (MEX-N3, MEX-G2). The remaining sites are "Los Humeras" with $25 \mathrm{MW}$ in Puebla and "La Primavera" in Jalisco with 10 MW. In contrast to reference MEX-N1, reference MEX-N3 states that the proven reserves for geothermal generation are $1.2 \mathrm{GW}$, with the possibility to find three times as much.

Several other geothermal fields are developing in Mexico. The field in Laguna Salada has a depth of $2,404 \mathrm{~m}$ and $126^{\circ} \mathrm{C}$ (MEX-G3).

\section{Hydro Resources}

There is a potential of $80 \mathrm{TWh} / \mathrm{yr}$ hydropower capacity in Mexico's rivers. However, at the present time, only $34 \%$ of this resource is used. There are plans, though, to double hydroelectric capacity by the year 2010, mostly through large-scale projects. Also, there is a possibility for increasing hydroelectric capacity through micro/mini-hydro projects that do not have the negative environmental effect as do the large projects (MEX-N1.)

Nevertheless, small hydropower development has been quite slow in Mexico. The last plant was built more than 30 years ago with a 624-kW capacity. There are now 92 small units, each with 5 MW or less, interconnected to the grid for a total of 137.5 MW. Also, there are 15 small (10 to $125 \mathrm{~kW}$ ), hydro plants in several states with $463 \mathrm{~kW}$ total (MEX-N3). 
Table of References for Mexico (see key following table for abbreviation and resource codes):

\begin{tabular}{|c|c|c|c|c|c|c|}
\hline Type of Analysis & Wind & Solar & Biomass & Geothermal & Hydro & General \\
\hline $\begin{array}{l}\text { Site-Specific } \\
\text { Analysis }\end{array}$ & MEX-W1 & $\begin{array}{l}\text { MEX-S3 } \\
\text { MEX-S4 }\end{array}$ & & $\begin{array}{l}\text { MEX-G2 } \\
\text { MEX-G3 } \\
\text { MEX-N3 }\end{array}$ & & \\
\hline $\begin{array}{l}\text { Country-Wide } \\
\text { Surveys }\end{array}$ & MEX-W1 & $\begin{array}{l}\text { MEX-S2 } \\
\text { MEX-S4 }\end{array}$ & & & & \\
\hline Country-Wide Maps & MEX-W1 & $\begin{array}{l}\text { MEX-S1 } \\
\text { MEX-S2 } \\
\text { MEX-S5 } \\
\text { MEX-S8 } \\
\text { MEX-S9 }\end{array}$ & & & & \\
\hline $\begin{array}{l}\text { Modeled Data } \\
\text { Sources }\end{array}$ & & $\begin{array}{l}\text { MEX-S6 } \\
\text { MEX-S7 } \\
\text { MEX-S9 }\end{array}$ & & & & \\
\hline $\begin{array}{l}\text { Measured Data } \\
\text { Sources }\end{array}$ & MEX-W1 & $\begin{array}{c}\text { MEX-S1 } \\
\text { MEX-S2 } \\
\text { MEX-S3 } \\
\text { MEX-S4 } \\
\text { MEX-S8 } \\
\text { SE-S1 }\end{array}$ & & MEX-N3 & & MEX-N1 \\
\hline $\begin{array}{l}\text { Technology or } \\
\text { Economic } \\
\text { Assessment Only }\end{array}$ & $\begin{array}{l}\text { MEX-N1 } \\
\text { MEX-N3 }\end{array}$ & MEX-N3 & $\begin{array}{l}\text { MEX-N1 } \\
\text { MEX-N2 } \\
\text { MEX-N3 }\end{array}$ & MEX-N1 & $\begin{array}{l}\text { MEX-N1 } \\
\text { MEX-N3 }\end{array}$ & MEX-N1 \\
\hline
\end{tabular}

Key:

$\underline{\text { Abbreviations }}$

Mexico $=$ MEX

South East Asia Region $=$ SE $\underline{\text { Resources }}$

Wind $=\mathrm{W}$

Solar $=$ S

Biomass $=\mathrm{B}$

Geothermal $=\mathrm{G}$

Hydro $=\mathrm{H}$

General $=\mathrm{N}$ 


\section{New Zealand (NZ)}

\section{Overview of New Zealand's Energy Production}

New Zealand's current electricity demand is about $30,000 \mathrm{GWh}, 70 \%$ to $85 \%$ of which is generated by hydropower. Natural gas supplies most of the remaining capacity (20-25\%); the balance (3-4\%) is supplied by geothermal (NZ-B2, NZ-B1). Thus, as we can see from the attached chart, New Zealand is entirely dependent on renewable resources for electricity supply. The total energy supply, however, comes from a variety of sources. (NZ-N2) Current electricity prices in New Zealand are about U.S. $\$ 0.04-\$ 0.55 / \mathrm{kWh}$ (NZ-B2).

Conventional fuels, such as coal and gas, are used as cheap sources of heat; renewables cannot yet compete economically in this area. Several specific sites have easy access to biogas and wood residues, which can be used as alternative heat sources (NZ-N2).

\section{Wind Resources}

New Zealand is one of the windiest places on earth due to its location and mountainous terrain. There are a few sites where wind speed is more than $10 \mathrm{~m} / \mathrm{s}$ at a height of $25 \mathrm{~m}$ above ground (NZ-N2).

Wind power generation costs from U.S. $\$ 0.05-\$ 0.10 / \mathrm{kWh}(\mathrm{NZ}-\mathrm{B} 2)$. A wind energy resource survey was conducted in 1974 in response to the oil crisis (NZ-W2). The best sites were typically at ridge crests.

Nevertheless, before 1990 there had been no attempts to run a pilot wind farm or even a well-positioned wind electricity generator (NZ-W1). Since that time, however, wind technology has begun to develop, albeit slowly because of many uncertainties, including operating and maintenance costs. In 1992, a 225-kW Vestas turbine generated more than $1 \mathrm{GWh}$ during the first 12 months of operation in Wellington city, a record for a turbine this size. In 1996, two wind farms, $65 \mathrm{MW}$ and $4 \mathrm{MW}$ respectively, have received planning consents. A smaller plant is already under construction. As soon as the first wind farm proves to be efficient, others will likely be constructed soon (NZ-N2).

\section{Solar Resources}

On a clear day, New Zealand receives up to $1,000 \mathrm{~W} / \mathrm{m}^{2}$. The average global horizontal irradiation in Wellington has been measured at $3.80 \mathrm{kWhm}^{-}{ }^{2} \mathrm{day}^{-}{ }^{1}$ (SE-S1). Therefore, solar thermal and PV systems, and passive solar building design, are all feasible technologies. There is potential to produce as much as $1,500 \mathrm{GWh}$ (an equivalent to a hydroelectric station of $350 \mathrm{MW}$ ). Despite successful demonstrations, though, these technologies are not yet put to use because the $>5$-yr payback period is considered too long (NZ-N2).

Three types of pyranometers have been used to study solar resources in the member economy:

- An Eppley Precision Spectral pyranometer

- $\quad$ Five Li-Cor-type 2000SB pyranometers

- $\quad$ An Eppley Black and White pyranometer mounted in a shading band. 
An indicator of sky condition is the "clearness index," $K_{T}$, defined earlier as $K_{T}=H / H_{o}$. For New Zealand, $\mathrm{K}_{\mathrm{T}}$ ranges between 0.1 and 0.75 .

Equations for estimating diffuse-to-global and diffuse-to-extraterrestrial radiation ratios have been derived for the member economy as follows (NZ-S1):

where:

$$
\begin{aligned}
& \mathrm{H}_{\mathrm{d}} / \mathrm{H}=1+0.146 \mathrm{~K}_{\mathrm{T}}-2.95 \mathrm{~K}_{\mathrm{T}}^{2}+1.56 \mathrm{~K}_{\mathrm{T}}^{3} \\
& \mathrm{H}_{\mathrm{d}} / \mathrm{H}_{\mathrm{o}}=1.01 \mathrm{~K}_{\mathrm{T}}+0.0708 \mathrm{~K}_{\mathrm{T}}^{2}-2.77 \mathrm{~K}_{\mathrm{T}}^{3}+1.43 \mathrm{~K}_{\mathrm{T}}^{4}
\end{aligned}
$$

$$
\mathrm{H}_{\mathrm{d}}=\text { daily diffuse radiation }
$$

The diffuse coefficient for solar radiation is lower in June, July, and August on clear days; it is also lower than observed in the United States. At high values of clearness, the diffuse ratio was much lower than observed elsewhere (NZ-S1).

\section{Biomass Resources}

New Zealand's climate is favorable for fast-growing tree crops. For example, more than 70 oven dry tonne/ha/yr has been recorded for eucalyptus trees at Masey University (NZ-N2). Even without irrigation, fertilizer, weed control, and other agricultural tools, a trial of coppice trees, harvested on a 3 -year rotation over 12 years has produced $24 \mathrm{odt} / \mathrm{ha} / \mathrm{yr}$. Thus, similar commercial rates are to be expected.

For biomass fuels, 10-20 MW capacity power plants are feasible for now, and 40-50 MW for the future. While the present conversion efficiency is around $20 \%$, there is potential for it to reach $40 \%$. In the near future biomass fuels will likely be able to compete on a cost basis with hydropower and wind (NZ-B2). The use of plantation forests, wood processing residues, energy plantations (including short-rotation coppice trees and cereal straw), are considered to have future applications, as are other renewable energy sources (NZ-B3). Exotic forest arisings could supply $970 \mathrm{GWh} / \mathrm{yr}$ by the year 2002; wood processing residues, $289 \mathrm{GWh} / \mathrm{yr}$, and fuelwood plantations, 2,060 GWh/yr with a potential 10,000 GWh/yr by 2012 (NZ-B1). The current plantation forest area is 1.3 million ha. Most of it is under young age classes of Pinus radiata, so a doubling of present wood production is expected by 2005 (NZ-B2). The greatest potential is expected from energy plantations. Yields of $20 \mathrm{odt} / \mathrm{ha} / \mathrm{yr}$ are assumed based on current field trials. Species selection can improve the yields (NZ-B1, NZ-B2). A large forest company is planning to install a $34 \mathrm{MW}$ (electric) co-generation plant at its pulp mill, using wood processing residues. Several anaerobic digestion plants have been installed to treat food processing wastes, but the total resource is limited (NZ-N2).

There is a possibility to replace some of the natural gas-generated electricity with biomass-generated, but gas turbine power is considered to be more cost effective (NZ-B2, NZ-H1).

\section{Geothermal Resources}

The development of geothermal fields is promising (NZ-N2). An estimated 9,750 GWh is available at relatively low cost. Binary generation potential, which uses lower temperature sources, can double this number. Three landfill gas sites are operating; a $46 \mathrm{MW}$ geothermal field was under construction and due to be operational by September 1996. 


\section{Hydro Resources}

Hydropower development is not likely to continue because a few underdeveloped waterways remain (NZ-H1). However, a report published by the Ministry of Commerce in 1993 stated that undeveloped hydropower could provide more than 44,000 GWh annually. Due to public disapproval of large hydro projects, which involve excessive damming, only small hydro is expected in the immediate future (NZ-N2).

Table of References for New Zealand (see key following table for abbreviation and resource codes):

\begin{tabular}{|l|c|c|c|c|c|c|}
\hline \multicolumn{1}{|c|}{ Type of Analysis } & Wind & Solar & Biomass & Geothermal & Hydro & General \\
\hline \hline $\begin{array}{l}\text { Site-Specific } \\
\text { Analysis }\end{array}$ & & & NZ-N2 & & & \\
\hline $\begin{array}{l}\text { Country-Wide } \\
\text { Surveys }\end{array}$ & NZ-W1 & & NZ-N1 & & & $\begin{array}{l}\text { NZ-N2 } \\
\text { NZ-N3 }\end{array}$ \\
\hline Country-Wide Maps & & & & & & \\
\hline $\begin{array}{l}\text { Modeled Data } \\
\text { Sources }\end{array}$ & & NZ-S1 & & & & \\
\hline $\begin{array}{l}\text { Measured Data } \\
\text { Sources }\end{array}$ & NZ-W1 & $\begin{array}{c}\text { NZ-S1 } \\
\text { NZ-N2 } \\
\text { AUS-S2 } \\
\text { SE-S1 }\end{array}$ & $\begin{array}{l}\text { NZ-B1 } \\
\text { NZ-B2 }\end{array}$ & NZ-N2 & NZ-N2 & NZ-B1 \\
NZ-B2 \\
\hline $\begin{array}{l}\text { Technology or } \\
\text { Economic } \\
\text { Assessment Only }\end{array}$ & $\begin{array}{l}\text { NZ-W2 } \\
\text { NZ-B2 } \\
\text { NZ-N2 }\end{array}$ & NZ-N2 & $\begin{array}{l}\text { NZ-B2 } \\
\text { NZ-B3 }\end{array}$ & NZ-N2 & $\begin{array}{l}\text { NZ-H1 } \\
\text { NZ-N2 } \\
\text { NZ-B2 }\end{array}$ & $\begin{array}{l}\text { NZ-B2 } \\
\text { NZ-N2 }\end{array}$ \\
\hline
\end{tabular}

Key:

\section{Abbreviations}

New Zealand $=\mathrm{NZ}$

Australia = AUS

South East Asia Region = SE $\underline{\text { Resources }}$

Wind $=\mathrm{W}$

Solar $=S$

Biomass $=\mathrm{B}$

Geothermal = G

Hydro $=\mathrm{H}$

General $=\mathrm{N}$ 


\section{Papua New Guinea (PNG)}

\section{Overview of Papua New Guinea's Energy Production}

In Papua New Guinea (PNG) there is a very high need for energy in the rural areas where $87 \%$ of the population lives. Yet in urban areas there is an excess of installed electricity supplied by large hydroelectric facilities (PNG-N2).

Transportation to rural areas is very expensive. Traditional energies used for lighting are from open hearths and kerosene-fueled lanterns. But because kerosene supply has to be flown in, it becomes much more expensive. Firewood supplys from nearby bushes and local sawmills are limited. Solar kits with a supply of batteries may be more practical (PNG-N1).

\section{Wind Resources}

Wind systems have not been installed during the past 8 years, and wind technologies currently are not in popular use. No known assessment of wind resources for the member economy has been identified.

\section{Solar Resources}

Nix and Kalma used Haunam's data in the Angstrom-type equation (see equation (1)) to estimate total annual solar radiation for 33 stations in Northern Australia and Papua New Guinea.: The empirical coefficients $a=0.26$ and $b=0.50$ were obtained by Haunam through 458 monthly observations from six Australian stations, ranging from 3 to 10 years (AUS-S2).

Page's modification of this equation required sunshine records for the 5-year period. These modifications were applied in reference PNG-S1, and the coefficients were calculated to be $\mathrm{a}=$ 0.32 and $b=0.48$, somewhat different from Haunam's data.

Solar measurements at Lae, Papua New Guinea, were made using an Eppley Black and White pyranometer with a wire-wound copper-contastan thermopile as the detector (PNG-S1).. The recorded data from University of Technology at Lae were sent to Australia's CSIRO for analysis. The duration of sunshine is measured by a Campbell-Stokes sunshine recorder. The following table shows the mean daily radiation values and daily sunshine duration at Lae for various periods throughout the year (PNG-S1):

\begin{tabular}{|l|c|c|}
\hline \multicolumn{1}{|c|}{ Period } & Mean Radiation $\mathrm{kWh} / \mathrm{m} 2 *$ & Duration \\
\hline \hline January 14-February 26 & 5.67 & 11.73 \\
\hline February 27-April 12 & 5.36 & 12.00 \\
\hline April 13-May 28 & 5.02 & 12.26 \\
\hline May 29-July 15 & 4.58 & 12.39 \\
\hline July 16-August 31 & 4.03 & 12.25 \\
\hline September 1-October 15 & 5.70 & 11.98 \\
\hline
\end{tabular}




\begin{tabular}{|c|c|c|}
\hline Period & Mean Radiation $\mathrm{kWh} / \mathrm{m} 2^{*}$ & Duration \\
\hline \hline October 16-November 19 & 6.20 & 11.72 \\
\hline November 20-January 13 & 6.10 & 11.61 \\
\hline
\end{tabular}

Based on measurements at the University of Papua New Guinea in Port Moresby, the most favorable solar resource occurs from September through February, when the daily radiation ranges from 5.67 to $6.20 \mathrm{~kW} / \mathrm{m}^{2}$. The maximum insolation reaches 790 to $830 \mathrm{~W} / \mathrm{m}^{2}$ at noon in Lae from November through February. The remaining part of the year, from March through August, is the rainy season, and the solar resource diminishes. During most of the year, there is an increase in afternoon cloudiness. The highest daily mean isolation is observed in October at $6.35 \mathrm{kWh} / \mathrm{m}^{2}$ (PNG-S3).

The U.S. Department of Energy's Atmospheric Radiation Measurement Program established an extensive cloud and surface radiation measurement station at Kavieng $\left(2^{\circ} 34^{\prime} \mathrm{S}, 150^{\circ} 48^{\prime} \mathrm{E}\right)$ in collaboration with the Tropical Oceans-Global Atmosphere Coupled Ocean-Atmopsheric Research Experiment from November 1992-May 1993 (PNG-S2). Some solar measurements continued at Kavieng beyond that time.

PV systems are used in PNG as stand-alone or remote power sources, but various hybrid systems are considered promising. Solar hot water systems are used for commercial applications, but they are developing slowly; partly because of hard water problems (PNG-N1).

\section{Biomass Resources}

For the member economy to replace diesel plants burning expensive imported oil, biomass or waste-fired generation stations could be used. Biomass has an advantage of being a simple technology that is easy to maintain. So far, the only food industry in the country that generates its own power from biomass (bagasse) is Ramu Sugar, which supplies sugar needs for the entire country and exports 7,000 tonnes of it to the United States (PNG-N1).

\section{Geothermal Resources}

Helium isotope ratios ${ }^{3} \mathrm{He} /{ }^{4} \mathrm{He}$ have been measured and studied in geothermal gases from the Tabar-Lihir-Tanga-Feni chain in the Bismarck Archipelago of PNG. The findings of this study were published in detail in 1995 (PNG-G1).

\section{Hydro Resources}

There is a substantial hydropower potential in PNG because of its mountainous terrain and abundant rainfall, but the data on this resource is not sufficient (PNG-N1; PNG-H2). Most rural communities can access the water resources through micro-hydro systems. This source is particularly important because only the major towns are served by the national electricity system. Extensive financial help must be made available to PNG to expedite the rural electrification process (PNG-H2).

Small hydro and experimental PV devices are used to power vaccine refrigerators in villages. The costs are similar, but very small hydro devices are preferred because this technology includes water supply to the villages and can provide emergency lighting. Compared to conventional micro hydro power plants with $5 \mathrm{KVA}$ and $240 \mathrm{~V}$ AC output, which require expensive design, 
installation, and maintenance, small (50- to 100-W) devices are well suited for the villagers' needs (PNG-N1).

There is a need for small prime movers with less than $100 \mathrm{~W}$ output for operating agricultural machines. Water resources are abundant in many areas, so that water-wheels can be used for powering hand-driven machinery (PNG-N1).

The Enga Province, which covers $10,790 \mathrm{~km}^{2}$, is home to 165,000 people. There is an increasing demand for energy. Since 1984, feasibility studies were conducted there for the Anditale micro hydro plant. In October 1988, the construction started. Even though it was envisioned to be finished by the end of 1989, administrative, budgetary, and natural events slowed the process, so the plant was still not complete in 1991 (PNG-H1).

Table of References for Papua New Guinea (see key following table for abbreviation and resource codes):

\begin{tabular}{|l|c|c|c|c|c|c|}
\hline \multicolumn{1}{|c|}{ Type of Analysis } & Wind & Solar & Biomass & Geothermal & Hydro & General \\
\hline \hline $\begin{array}{l}\text { Site-Specific } \\
\text { Analysis }\end{array}$ & & PNG-S1 & & PNG-G1 & $\begin{array}{c}\text { PNG-H1 } \\
\text { PNG-H3 }\end{array}$ & \\
\hline $\begin{array}{l}\text { Country-Wide } \\
\text { Surveys }\end{array}$ & & PNG-S1 & & & & \\
\hline Country-Wide Maps & & & & & & \\
\hline $\begin{array}{l}\text { Modeled Data } \\
\text { Sources }\end{array}$ & $\begin{array}{l}\text { PNG-S1 } \\
\text { AUS-S2 }\end{array}$ & & & & \\
\hline $\begin{array}{l}\text { Measured Data } \\
\text { Sources }\end{array}$ & $\begin{array}{l}\text { PNG-S1 } \\
\text { PNG-S2 } \\
\text { AUS-S1 }\end{array}$ & & PNG-G1 & & \\
\hline $\begin{array}{l}\text { Technology or } \\
\text { Economic } \\
\text { Assessment Only }\end{array}$ & PNG-N1 & PNG-N1 & & $\begin{array}{l}\text { PNG-N1 } \\
\text { PNG-H2 }\end{array}$ & PNG-N1 \\
\hline
\end{tabular}

Key:

\section{Abbreviations}

Papua New Guinea $=$ PNG

Australia $=$ AUS
Resources

Wind $=\mathrm{W}$

Solar $=S$

Biomass $=\mathrm{B}$

Geothermal = G

Hydro $=\mathrm{H}$

General $=\mathrm{N}$ 


\section{Republic of the Philippines (RP)}

\section{Overview of the Philippines' Energy Production}

In 1991, electric power generation in the Republic of the Philippines was $47.5 \%$ oil-based, $32 \%$ hydropower, $14 \%$ geothermal, and around 6\% coal. The total installed capacity was 6,521 MW, but for the period 1993 to 2005 an additional 20,698 MW of new capacity is planned. This includes 14 hydro projects ranging from 20-390 MW, 1,673 MW of geothermal power, $288 \mathrm{MW}$ of coal, $988 \mathrm{MW}$ of diesel, $930 \mathrm{MW}$ of gas turbine capacity, 2,835 MW of combined cycle capacity, and two generic blocks of small hydro for Mildanao with a total of 1,872 MW (RP-H1).

In 1993, nonconventional energy contributed approximately 15.62 million BOE or $14 \%$ of the member economy's total energy mix. This share was largely composed of bagasse and agricultural wastes, such as coco wastes, wood waste, and rice hulls (RP-S1).

The present 1993-2000 Medium-term Nonconventional Energy Program considers PV as a first priority technology (RP-S1). The policies for the Nonconventional Energy Sector (NES) are to:

- Intensify promotion of judicious use of nonconventional energy resources.

- $\quad$ Help the private sector manufacture NES equipment and devices.

- $\quad$ Create a favorable market environment for buyers and sellers of NES.

- $\quad$ Institutionalize area-based energy planning and management for NES.

- Support commercial-scale NES projects that are environmentally friendly, cost effective, and socially desirable.

- Support technological research and development activities on NES.

- $\quad$ Enhance coordination and planning of NES policy and programs.

The following table shows the member economy's energy consumption levels compared with a few of its Asean neighbors (SE-N3): 


\begin{tabular}{|l|c|}
\hline \multicolumn{1}{|c|}{ Country } & Per-Capita Energy Consumption (toe) \\
\hline \hline Brunei & 3.80 \\
\hline Indonesia & 0.23 \\
\hline Malaysia & 0.78 \\
\hline Philippines & 0.38 \\
\hline Singapore & 4.46 \\
\hline Thailand & 0.33 \\
\hline
\end{tabular}

The breakdown of resources for the country is as follows (SE-N3):

\begin{tabular}{|c|c|c|c|c|}
\hline $\begin{array}{c}\text { Oil } \\
\text { (billion bbl) }\end{array}$ & $\begin{array}{c}\text { Gas } \\
\text { (trillion } \mathrm{m}^{3} \text { ) }\end{array}$ & $\begin{array}{c}\text { Coal } \\
\text { (billion tonnes) }\end{array}$ & $\begin{array}{c}\text { Hydro } \\
\text { MW }\end{array}$ & $\begin{array}{c}\text { Geothermal } \\
\text { MW }\end{array}$ \\
\hline \hline 0.020 & 22,000 & $\begin{array}{c}1,500 \\
\text { (Bituminous) }\end{array}$ & 10,000 & 6,000 \\
\hline
\end{tabular}

\section{Wind Resources}

A comprehensive assessment of the wind energy resources for the Philippines has not been identified in the open literature. Some limited information is provided in reference SE-N1, which notes that the yearly average wind velocity is $3.6-5.6 \mathrm{~m} / \mathrm{s}$, although the height of the measurements is not identified.

\section{Solar Resources}

The average daily total solar radiation in the Philippines ranges from 5.8 to $6.38 \mathrm{kWh} / \mathrm{m}^{2}$ day in June, and from 3.48 to $4.06 \mathrm{kWh} / \mathrm{m}^{2}$ day in December (SE-N1).

The locations with the highest averaged global horizontal solar radiation are (SE-S1):

\begin{tabular}{|l|c|}
\hline \multicolumn{1}{|c|}{ Location } & Yearly Average Radiation \\
\hline \hline Maligaya & $5.90 \mathrm{kWhm}^{-2}{ }^{2}{ }^{1}{ }^{1}$ \\
\hline Sto Tomas & $5.21 \mathrm{kWhm}-^{2}{ }^{\text {day- }}{ }^{1}$ \\
\hline Solona & $5.17 \mathrm{kWhm}^{2}{ }^{2}$ day- $^{1}$ \\
\hline
\end{tabular}


PV research is currently being conducted for water pumping and power supply (SE-N1). There is great potential for using PV systems for domestic (household) applications, particularly in households located off the grid, small islands, and inaccessible areas (RP-S1).

\section{Biomass Resources}

The conversion of biomass wastes into energy typically involves utilization of biomass, classified as new plant growth, biomass residues and wastes. In the Philippines, this conversion uses the three following processes (RP-B1):

- The direct combustion process is the most mature technology and is used with most commercially available systems.

- The thermochemical process involves thermal gasification.

- The biochemical process is anaerobic digestion or methane and ethanol fermentation.

In the Philippines, the total forest area is approximately 11 million ha, $75 \%$ of which belongs to the Depterocarp (meranti) group. Since the 1960s, log production has declined substantially to only 3 million $\mathrm{m}^{3}$ in 1984 (INA-B1).

The biogas production potential is $10.1 \mathrm{mil} \mathrm{m}^{3}$ (SE-N1).

\section{Geothermal Resources}

Overall, The Republic of the Philippines is the world's second largest producer of geothermal electricity at 1,000 MW (RP-G1). In 1992, four plants supplied $20 \%$ of the member economy's electric needs with $14 \%$ coming from geothermal steam. But this high capacity, developed during the mid-1980s, has not been substantially upgraded since, despite the growing demand for energy and uncertainty about crude oil supply. There are plans, though, to expand the capacity by 270 MWe to 1,100 MWe by 1999 , and by 20,000 MWe during the next 15-20 years through independent power producers (RP-G7, RP-G1).

The Greater Tongonian geothermal field is being developed on the island of Leyte by the Philippine National Oil Company, Energy Development Corporation (RP-G3). Another geothermal field is located in Palinpinon. The factors that affect development decisions at Tongonian include regional power demand, topography, and extent of the resource. The Palinpinon development is less constrained by regional power demand, but is limited by rugged terrain and physical characteristics (RP-G5).

The Tongonian field can be exploited at a high-pressure operating condition with substantial improvement in the field capacity. The upper Mahiao and Malitbog sectors can generate up to 395 MWe at $1.0 \mathrm{MPa}$ abs, in addition to the current $112.5 \mathrm{MWe}$ plant. If the field is operated at 0.6 $\mathrm{MPa}$ abs, $275 \mathrm{MWe}$ of additional capacity can be generated. The total capacity for the proposed Leyte $640 \mathrm{MWe}$ expansion can be generated from these sectors plus the power from Mahanagdong and Alto Peak sectors (RP-G6).

\section{Hydro Resources}

There is a growing interest in private hydropower development in the Philippines. There are many attractive sites, but they are currently considered to be risky investments. However, thermal power has been successfully implemented through privatization, so investment in small-scale 
hydro is possible. In the development program up to 2005 , the following hydro sites are listed (RP-H1):

- $\quad$ Kalayaa Pumped Storage project expansion: $300 \mathrm{MW}$

- Amburayan project: $93 \mathrm{MW}$

- $\quad$ San Roque multipurpose: $93 \mathrm{MW}$

- $\quad$ Agus I: $40 \mathrm{MW}$

- $\quad$ Agus III: $224 \mathrm{MW}$

- Bulanag-Batang: $150 \mathrm{MW}$

- $\quad$ Pulangi V: $300 \mathrm{MW}$.

Also, feasibility studies have identified 35 of 46 possible hydro sites in four regions (RP-H1).

Table of References for the Republic of the Philippines (see key following table for abbreviation and resource codes):

\begin{tabular}{|l|l|l|l|l|l|l|}
\hline \multicolumn{1}{|c|}{ Type of Analysis } & Wind & Solar & Biomass & Geothermal & Hydro & General \\
\hline \hline $\begin{array}{l}\text { Site-Specific } \\
\text { Analysis }\end{array}$ & & & & $\begin{array}{l}\text { RP-G5 } \\
\text { RP-G6 }\end{array}$ & & \\
\hline $\begin{array}{l}\text { Country-Wide } \\
\text { Surveys }\end{array}$ & & RP-S1 & & & & \\
\hline Country-Wide Maps & & & & & & \\
\hline $\begin{array}{l}\text { Modeled Data } \\
\text { Sources }\end{array}$ & & & & & & \\
\hline $\begin{array}{l}\text { Measured Data } \\
\text { Sources }\end{array}$ & SE-N1 & SE-N1 & SE-N1 & SE-N1 & & SE-N3 \\
\hline $\begin{array}{l}\text { Technology or } \\
\text { Economic } \\
\text { Assessment Only }\end{array}$ & & SE-S1 & & SE-N3 & & RP-H1 \\
\hline
\end{tabular}

Key:

\section{$\underline{\text { Abbreviations }}$}

Republic of the Philippines $=\mathrm{RP}$ Indonesia = INA

South East Asia Region = SE

\section{Resources}

$$
\begin{aligned}
& \text { Wind = W } \\
& \text { Solar = S } \\
& \text { Biomass = B } \\
& \text { Geothermal = G } \\
& \text { Hydro = H } \\
& \text { General = N }
\end{aligned}
$$




\section{Singapore (SIN)}

\section{Overview of Singapore's Energy Production}

Singapore has the highest energy consumption per capita in the Asean region. The following table shows Singapore's energy consumption levels compared with a few of its Asean neighbors (SIN-N3):

\begin{tabular}{|l|c|}
\hline \multicolumn{1}{|c|}{ Country } & Per-Capita Energy Consumption (toe) \\
\hline \hline Brunei & 3.80 \\
\hline Indonesia & 0.23 \\
\hline Malaysia & 0.78 \\
\hline Philippines & 0.38 \\
\hline Singapore & 4.46 \\
\hline Thailand & 0.33 \\
\hline
\end{tabular}

Singapore is characterized by equatorial monsoon weather, with two distinct monsoon seasons. The northeastern monsoon (from December to March) brings windy conditions and heavy rainfall (SIN-S5). The southwestern monsoon (June to September) brings drier conditions. December is the wettest month with $254 \mathrm{~mm}$ of rain, and July the driest with $163 \mathrm{~mm}$. The average yearly rainfall is $2,413 \mathrm{~mm}$. The mean temperature is $26.7^{\circ} \mathrm{C}$ with average daily maximum of $36^{\circ} \mathrm{C}$. The average relative humidity is $84 \%$ (SIN-S1).

\section{Wind Resources}

The following table shows the monthly distribution of wind speeds obtained at the weather service station at the Singapore airport (SIN-S1, SIN-S3):

\begin{tabular}{|l|c|}
\hline \multicolumn{1}{|c|}{ Month } & Wind Speed $(\mathrm{m} / \mathrm{s})$ \\
\hline \hline January & 2.30 \\
\hline February & 2.40 \\
\hline March & 1.58 \\
\hline April & 1.24 \\
\hline May & 1.05 \\
\hline June & 1.58 \\
\hline July & 1.41 \\
\hline
\end{tabular}




\begin{tabular}{|l|c|}
\hline \multicolumn{1}{|c|}{ Month } & Wind Speed $(\mathrm{m} / \mathrm{s})$ \\
\hline \hline August & 1.72 \\
\hline September & 1.77 \\
\hline October & 1.61 \\
\hline November & 1.46 \\
\hline December & 2.57 \\
\hline
\end{tabular}

These values are quite low and are likely not indicative of December, January, and February locations in the member economy. Nevertheless, in the absence of any more definitive wind resource assessment, this table shows that the highest wind speeds occur from December through February (during the monsoon) (SIN-S1, SIN-S3).

\section{Solar Resources}

For a period of 14 years, data on solar radiation has been collected with an actinograph at the Meteorological Department at Paya Lebar Airport in the eastern part of the island. The hourly solar radiation can vary from $50 \mathrm{Wh} / \mathrm{m}^{2}$ at $6: 00 \mathrm{am}$ and 6:00 $\mathrm{pm}$ to $680 \mathrm{Wh} / \mathrm{m}^{2}$ at noon (SIN-S5). Most days, solar radiation stays above $4.0 \mathrm{kWh} / \mathrm{m}^{2}$ day. The lowest daily mean solar radiation occurs in November at $3.36 \mathrm{kWh} / \mathrm{m}^{2}$ day; the highest occurs in February at $4.9 \mathrm{kWh} / \mathrm{m}^{2}$ day.

The Angstrom equation (1) was also used to examine the data. The regression coefficients, a and $\mathrm{b}$, were calculated as follows:

\begin{tabular}{|c|c|c|}
\hline Year & $\mathrm{a}$ & $\mathrm{b}$ \\
\hline \hline 1962 & 0.234 & 0.493 \\
\hline 1966 & 0.274 & 0.471 \\
\hline 1970 & 0.259 & 0.422 \\
\hline 1964 & 0.245 & 0.494 \\
\hline
\end{tabular}

The monthly values of $a$ and $b$ vary from 0.231 to 0.284 and from 0.411 to 0.506 , respectively. There is a great degree of uncertainty in this approach, so regression analysis of solar data with sunshine records does not necessarily result in accurate estimates at the sunshine recorder sites (SIN-S1).

A more comprehensive measurement study was conducted between 1965 and 1974 by the Meteorological Service of Singapore, with more recent measurements obtained at the Department of Building Sciences at the University of Singapore (SI-S4). For the earlier measurements, an Eppley Black and White pyranometer was used. A Kipp and Zonen solarimeter with shade ring was used for diffuse sky measurements. The study showed that even though the percentage of actual sunshine is relatively low (about $30-48 \%$ of the total possible), the average daily total radiation is $60-70 \%$ of the corresponding clear day values. The average daily mean radiation 
intensities at noon are between 550 and $770 \mathrm{Wm}^{-2}$; on exceptionally clear days it can rise to 1,100 $\mathrm{W} / \mathrm{m}^{2}$. About $73 \%$ of a day's total radiation is received between 9:00 a.m. and 3:00 p.m. The monthly mean daily total solar radiation on a horizontal surface varies from $3.81 \mathrm{kWhm}-{ }^{2}$ day- ${ }^{1}$ in December to $4.96 \mathrm{kWhm}-{ }^{2}$ day- ${ }^{1}$ in March. The annual mean of $4.46 \mathrm{kWhm}-{ }^{2} \mathrm{~d}-{ }^{1}$ occurs about $65.5 \%$ of days. However, there are 52 single isolated days with less than $3 \mathrm{kWhm}^{-2} \mathrm{~d}^{-1}$.

The average value of the mean monthly clearness index $\mathrm{K}_{\mathrm{T}}$ can vary from 0.39 in December to 0.48 in March. On the average, daily total diffuse radiation varies from 1.5 to $2.4 \mathrm{kWhm}^{-2} \mathrm{day}^{-1}$. Hourly diffuse radiation varies from 50 to $250 \mathrm{kWhm}-{ }^{2} \mathrm{~h}-{ }^{1}$. Daily total solar energy levels greater than $4 \mathrm{kWhm}-{ }^{2}$ day- ${ }^{1}$ and with a $35-45 \%$ diff use component occur more than $75 \%$ of the days in a year.

This study (SN-S4) developed the following Angstrom-type relation:

$$
\mathrm{H} / \mathrm{H}_{\mathrm{o}}=0.18+0.58\left(\mathrm{n}_{\mathrm{a}} / \mathrm{N}_{\mathrm{p}}\right)
$$

where the units are defined as before (see equation (1)).

The ratio $\mathrm{H} / \mathrm{H}_{\mathrm{O}}$ was observed to vary from 0.2 to 0.75 . On clear days, when $\mathrm{K}_{\mathrm{T}}=0.7$, the daily diffuse radiation is $10-12 \%$ of extraterrestrial insolation, but on cloudy days $\left(\mathrm{K}_{\mathrm{T}}=0.4\right)$ this percentage is twice as much. On an average day, the total daily diffuse radiation can vary from 1.5 to $2.4 \mathrm{kWhm}-{ }^{2} \mathrm{~d}-{ }^{1}$, with hourly values ranging from 50 to $250 \mathrm{Whm}^{-}{ }^{2}{ }^{-1}{ }^{1}$ (SIN-S4).

In order to estimate the diffuse solar radiation component for Singapore, the Hawlader's model for correlating hourly diffuse radiation $\left(\mathrm{H}_{\mathrm{d}} / \mathrm{H}\right)$ with hourly clearness index $\mathrm{K}_{\mathrm{T}}$ can be used (INA-S1):

$$
\begin{aligned}
& \mathrm{H}_{\mathrm{d}} / \mathrm{H}=0.915\left(\text { for } 0<\mathrm{K}_{\mathrm{T}}<0.225\right) \\
& \mathrm{H}_{\mathrm{d}} / \mathrm{H}=1.135-0.9422 \mathrm{~K}_{\mathrm{T}}-0.3878 \mathrm{~K}_{\mathrm{T}}^{2} \text { (for } 0.225<\mathrm{K}_{\mathrm{T}}<0.775 \text { ) } \\
& \mathrm{H}_{\mathrm{d}} / \mathrm{H}=0.215\left(\text { for } \mathrm{K}_{\mathrm{T}}>0.775\right. \text { ) }
\end{aligned}
$$

The following table shows some typical monthly averaged values (SIN-S3):

\begin{tabular}{|l|c|c|}
\hline \multicolumn{1}{|c|}{ Month } & Daily Mean Global Radiation $\mathrm{kWh} / \mathrm{m}^{2}$ & Dry Bulb $\mathrm{C}^{\circ}$ Temperature \\
\hline \hline January & 4.00 & 25.9 \\
\hline February & 4.93 & 26.6 \\
\hline March & 4.45 & 27.1 \\
\hline April & 4.59 & 27.1 \\
\hline May & 3.88 & 27.5 \\
\hline June & 3.84 & 27.2 \\
\hline July & 4.11 & 26.9 \\
\hline
\end{tabular}




\begin{tabular}{|l|c|c|}
\hline \multicolumn{1}{|c|}{ Month } & Daily Mean Global Radiation $\mathrm{kWh} / \mathrm{m}^{2}$ & Dry Bulb $\mathrm{C}^{\circ}$ Temperature \\
\hline \hline August & 4.20 & 27.4 \\
\hline September & 4.19 & 26.8 \\
\hline October & 3.81 & 26.8 \\
\hline November & 3.36 & 25.9 \\
\hline December & 4.09 & 25.7 \\
\hline
\end{tabular}

The early part of the northeastern monsoon, which lasts from late November to March, brings rainy weather that can last several days. Thus, November shows the least solar radiation. Another monsoon lasts from late May to September (SIN-S3). Because of Singapore's equatorial climate, the variability in solar radiation from month to month is not significant. Given these conditions, there is a good potential for flat plate collector type solar devices for heating, drying, and air humidification and ventilation (SIN-S4).

The yearly averaged global horizontal solar irradiation varies between 4.35 and $4.42 \mathrm{kWh} / \mathrm{m}^{2}$ day (SE-S 1). 
Table of References for Singapore (see key following table for abbreviation and resource codes):

\begin{tabular}{|c|c|c|c|c|c|c|}
\hline Type of Analysis & Wind & Solar & Biomass & Geothermal & Hydro & General \\
\hline \multicolumn{7}{|l|}{$\begin{array}{l}\text { Site-Specific } \\
\text { Analysis }\end{array}$} \\
\hline $\begin{array}{l}\text { Country-Wide } \\
\text { Surveys }\end{array}$ & & SIN-S4 & & & & $\begin{array}{l}\text { SIN-S1 } \\
\text { SIN-S5 }\end{array}$ \\
\hline \multicolumn{7}{|l|}{ Country-Wide Maps } \\
\hline $\begin{array}{l}\text { Modeled Data } \\
\text { Sources }\end{array}$ & . & $\begin{array}{l}\text { SIN-S1 } \\
\text { SIN-S2 } \\
\text { INA-S1 }\end{array}$ & & & & \\
\hline $\begin{array}{l}\text { Measured Data } \\
\text { Sources }\end{array}$ & $\begin{array}{l}\text { SIN-S1 } \\
\text { SIN-S3 }\end{array}$ & $\begin{array}{c}\text { SIN-S1 } \\
\text { SIN-S3 } \\
\text { SIN-S4 } \\
\text { SIN-S5 } \\
\text { INA-S1 } \\
\text { SE-S1 }\end{array}$ & & & & SE-N3 \\
\hline $\begin{array}{l}\text { Technology or } \\
\text { Economic } \\
\text { Assessment Only }\end{array}$ & & SIN-S4 & & & & \\
\hline \multicolumn{4}{|l|}{ Key: } & \multicolumn{3}{|l|}{$\underline{\text { Resources }}$} \\
\hline $\begin{array}{l}\text { Abbreviations } \\
\text { Singapore = SIN } \\
\text { Indonesia = INA } \\
\text { South East Asia Regi }\end{array}$ & $\mathrm{n}=\mathrm{SE}$ & & & \multicolumn{3}{|c|}{$\begin{array}{l}\text { Wind }=\mathrm{W} \\
\text { Solar }=\mathrm{S} \\
\text { Biomass }=\mathrm{B} \\
\text { Geothermal = G } \\
\text { Hydro }=\mathrm{H} \\
\text { General }=\mathrm{N}\end{array}$} \\
\hline
\end{tabular}




\section{Chinese Taipei (CT)}

\section{Overview of Chinese Taipei's Energy Production}

More than $90 \%$ of Chinese Taipei's energy is imported, and most of this is oil (CT-N1). Renewable energy development priorities specific to Chinese Taipei are recommended as follows (CT-N1):

- Solar thermal

- $\quad$ PV systems, wind, and geothermal

- $\quad$ Fuel cells

- $\quad$ Bio-energy

- Ocean energy and hydrogen energy.

\section{Wind Resources}

A wind resource assessment has been developed for this member economy, showing a wind energy potential of more than $1000 \mathrm{MW}$. Wind energy systems rated at $4 \mathrm{~kW}, 40 \mathrm{~kW}$ and $150 \mathrm{~kW}$ units are being tested (CT-N1). Two $100 \mathrm{~kW}$ wind turbines have been installed to supplement the diesel power network of the Chi-Mei island (CT-W1). Because of their windy conditions, the Penghu islands have been identified for several wind power stations (CT-N3).

\section{Solar Resources}

The development potential of solar thermal energy is high; the total solar energy reaching the surface is 111 times the total energy consumption in 1977 in the member economy (CT-N1). The member economy lies in a subtropical zone and therefore has about 300 sunny days a year. The use of solar technologies for water heating had increased tenfold due to governmental support in the past, and is still increasing despite subsequent governmental withdrawal (CT-N3).

There is plenty of sunshine, especially in central and southern Chinese Taipei. This has allowed for the expanded use of solar collectors. Between 1986 and 1997, the annual solar collector area installed increased from $5,300 \mathrm{~m}^{2}$ to $8,000 \mathrm{~m}^{2}$. The performance of these systems has been upgraded and costs have been reduced. By using the present collector capacity, energy savings of about 40,000 tons of liquid petroleum gas (LPG) annually would be possible; thus, $\mathrm{CO}_{2}$ emissions can be reduced by 90,000 tons annually (CT-S1).

The development of PV systems has been limited to special applications due to the high cost of solar cell components. Over the short term, the price of oil is considerably lower. Development of more efficient cells is one strategy for reducing costs (CT-N1).

Fuel cells technology has great potential in the member economy. Ocean thermal and wave energy technologies have also been considered (CT-N1).

The locations with the highest global horizontal solar irradiation in the member economy are as follows (SE-S1): 


\begin{tabular}{|l|c|}
\hline \multicolumn{1}{|c|}{ Location } & Yearly Average Radiation \\
\hline \hline Taito & $4.96 \mathrm{kWhm}^{-}{ }^{2}$ day- $^{1}$ \\
\hline Tainan & $4.92 \mathrm{kWhm}^{-}{ }^{2}$ day- $^{-1}$ \\
\hline Kwarenko & $4.56 \mathrm{kWhm}^{-}{ }^{2}$ day- $^{1}$ \\
\hline
\end{tabular}

\section{Biomass Resources}

In the development of biomass-based power generation in the member economy, the emphasis is on the use of waste material (CT-N1).

\section{Geothermal Resources}

Chinese Taipei's explored geothermal sources of high temperature (greater than $150^{\circ} \mathrm{C}$ ) are Tuchan, Qinhhui, Datun, and Ushan (PRC-S5). The potential of geothermal energy in the member economy reaches $1000 \mathrm{MW}$. Two demonstration plants with a total of $3,300 \mathrm{~kW}$ have been installed. 
Table of References for Chinese Taipei (see key following table for abbreviation and resource codes):

\begin{tabular}{|l|l|l|l|l|l|l|}
\hline \multicolumn{1}{|c|}{ Type of Analysis } & Wind & Solar & Biomass & Geothermal & Hydro & General \\
\hline \hline $\begin{array}{l}\text { Site-Specific } \\
\text { Analysis }\end{array}$ & & & & & & \\
\hline $\begin{array}{l}\text { Country-Wide } \\
\text { Surveys }\end{array}$ & & & & PRC-S5 & & \\
\hline Country-Wide Maps & & & & & & \\
\hline $\begin{array}{l}\text { Modeled Data } \\
\text { Sources }\end{array}$ & & & & & & \\
\hline $\begin{array}{l}\text { Measured Data } \\
\text { Sources }\end{array}$ & & SE-S1 & & & & \\
\hline $\begin{array}{l}\text { Technology or } \\
\text { Economic } \\
\text { Assessment Only }\end{array}$ & $\begin{array}{l}\text { CT-N1 } \\
\text { CT-W1 } \\
\text { CT-N3 }\end{array}$ & $\begin{array}{l}\text { CT-N1 } \\
\text { CT-S1 } \\
\text { CT-S2 }\end{array}$ & CT-N1 & CT-N1 & & CT-N3 \\
\hline
\end{tabular}

Key:

$\underline{\text { Resources }}$

$\underline{\text { Abbreviations }}$

Chinese Taipei $=\mathrm{CT}$

People's Republic of China $=$ PRC

South East Asia Region = SE

Wind $=\mathrm{W}$

Solar $=\mathrm{S}$

Biomass $=\mathrm{B}$

Geothermal $=\mathrm{G}$

Hydro $=\mathrm{H}$

General $=$ N 


\section{Thailand (THA)}

\section{Overview of Thailand's Energy Production}

Thailand's economy is one of the fastest growing in the world. Its growth was mostly fueled by oil, even though there are several alternatives (mainly natural gas). Despite a recent economic downturn, strong economic growth should continue. Energy use will continue to grow as well (THA-N1). For the past 20 years, energy use was growing rapidly as the following table shows (THA-N8):

\begin{tabular}{|c|c|c|}
\hline Periods & GDP Rate & Energy Use Rate \\
\hline 1971-1979 & 7.3 & 7.7 \\
\hline $1979-1986$ & 4.9 & 2.1 \\
\hline 1971-1986 & 6.2 & 5.0 \\
\hline
\end{tabular}

By 1979, Thailand's energy intensity of output (ratio of total primary energy requirements to GDP) was the highest of all Asean economies, excluding the economy of Brunei Darussalam. From 1979 to 1986, household energy use increased 10\% and total population increased 15\%. At the same time, the measured household intensity of energy use declined from 103 toe per thousand population in 1979 to 98 toe in 1986. In rural areas, where most of Thailand's population (90\%) lives, fuelwood, which was used as a principal cooking fuel until the mid-1960s, has been replaced by commercially processed charcoal. However, substantial deforestation has already occurred in these areas (THA-N8).

At the end of 1996, the energy generation sources in Thailand were distributed according to the adjacent chart (THA-N7). In 1989, Thailand was importing some $47 \%$ of its energy. Domestically, particular emphasis was placed on development of natural gas, oil, biomass, and lignite. Little attention has been given to renewables. Because of depleted forests, the firewood industry is not likely to grow. In addition, public opposition to further dam construction limits the development of hydropower (THA-N6).

The following table shows Thailand's energy consumption levels compared with a few of its Asean neighbors (SE-N3):

\begin{tabular}{|l|c|}
\hline \multicolumn{1}{|c|}{ Country } & Per-Capita Energy Consumption (toe) \\
\hline \hline Brunei & 3.80 \\
\hline Indonesia & 0.23 \\
\hline Malaysia & 0.78 \\
\hline Philippines & 0.38 \\
\hline Singapore & 4.46 \\
\hline Thailand & 0.33 \\
\hline
\end{tabular}


The energy resources for Thailand are as follows (SE-N3):

\begin{tabular}{|c|c|c|c|c|}
\hline $\begin{array}{c}\text { Oil } \\
\text { (billion bbl) }\end{array}$ & $\begin{array}{c}\text { Gas } \\
\text { (trillion } \mathrm{m}^{3} \text { ) }\end{array}$ & $\begin{array}{c}\text { Coal } \\
\text { (billion tonnes) }\end{array}$ & $\begin{array}{c}\text { Hydro } \\
\text { MW }\end{array}$ & $\begin{array}{c}\text { Geothermal } \\
\text { MW }\end{array}$ \\
\hline \hline 0.080 & 9,600 & $\begin{array}{c}1,500 \\
\text { (Lignite) }\end{array}$ & 9,000 & -- \\
\hline \hline
\end{tabular}

\section{Wind Resources}

No extensive wind resource assessment has been conducted for Thailand, beyond an examination of weather service station records, which shows that the average yearly wind velocity in Thailand ranges from 3.6 to $4.6 \mathrm{~m} / \mathrm{s}$ (SE-N1). Wind power densities throughout Thailand are provided in reference PRC-W10, but these are based on weather service stations that are often found at poor wind sites. An assessment of the capabilities of wind turbines (THA-W1) showed that the multiple rotor and the sail-wing rotor is suitable for pumping water for domestic use at 43 locations; the slow-speed sail-wing rotor windmill is suitable for small irrigation water pumping at 32 locations; and the Aerowatt model (1100 GP56) is suitable for generating electricity for household use at 29 locations.

\section{Solar Resources}

Thailand receives from 4.64 to $5.8 \mathrm{kWh} / \mathrm{m}^{2}$ day solar radiation in June, and 4.06 to $4.64 \mathrm{kWh} /$ $\mathrm{m}^{2}$ day in December (SE-N1).

Fluctuations in daily solar radiation were examined for a continuous 5-year period of measurements in Bangkok and estimated from daily sunshine measurements at Bangkok and three other locations throughout the member economy (THA-S2). Bangkok is, overall, a good indicator of the distribution of solar resources throughout Thailand:

The following table shows the measurements obtained at Bangkok's KMITT and three other stations (THA-S6):

\begin{tabular}{|c|c|c|c|c|c|c|}
\hline \multirow[b]{2}{*}{ Station } & \multirow[b]{2}{*}{$\begin{array}{c}\text { Daily } \\
\text { Mean } \mathrm{K}_{\mathrm{t}}\end{array}$} & \multirow[b]{2}{*}{$\begin{array}{l}\text { Monthly } \\
\text { Mean } \mathrm{K}_{\mathrm{t}}\end{array}$} & \multicolumn{2}{|c|}{ Daily } & \multicolumn{2}{|c|}{ Monthly } \\
\hline & & & $\mathrm{a}$ & $\mathrm{b}$ & $\mathrm{a}$ & $\mathrm{b}$ \\
\hline KMITT & 0.5194 & 0.5082 & 0.3224 & 0.3697 & 0.3149 & 0.3859 \\
\hline Chiangmai & 0.5727 & 0.5694 & 0.3302 & 0.4087 & 0.3579 & 0.3531 \\
\hline Ubon Raja Thani & 0.5495 & 0.5534 & 0.3009 & 0.4076 & 0.2626 & 0.4526 \\
\hline Hat Yai & 0.5088 & 0.2733 & 0.2978 & 0.3826 & 0.2733 & 0.4344 \\
\hline
\end{tabular}


During the dry season, (December, through May) the frequency distribution of daily global solar radiation totals peaked at about $5.55 \mathrm{kWhm}^{-}{ }^{2}$ and skewed toward lower values of about 4.72 $\mathrm{kWhm}^{-2}$ in Bangkok. During the wet season (June through November), the distribution is more dispersed due to variable cloud amount. There are 32 isolated, 9.4 pairs and 3.4 runs of 3 days in a year when the radiation is less than $3.4 \mathrm{kWhm}-{ }^{2} \mathrm{~d}-{ }^{1}$. Such days are more likely to occur during the wet season, though in the south such runs are likely to happen at the end of the year

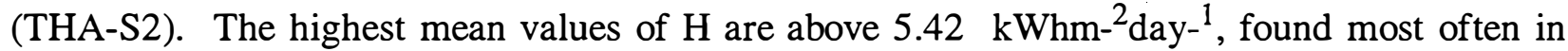
March, April, and May; the lowest are below $4.17 \mathrm{kWhm}^{-2}{ }^{2} \mathrm{day}-{ }^{1}$, occurring in restricted locations throughout the wet season (THA-S8).

The locations with the highest global horizontal irradiation are as follows (SE-S1):

\begin{tabular}{|c|c|}
\hline Location & Yearly Average Radiation \\
\hline Nong Khai & $6.00 \mathrm{kWhm}^{-2} \mathrm{day}^{-1}$ \\
\hline Bubol & $5.18 \mathrm{kWhm}^{2}{ }^{2}$ day- ${ }^{1}$ \\
\hline Bang Na & $5.02 \mathrm{kWhm}^{2}{ }^{2}$ day- ${ }^{1}$ \\
\hline
\end{tabular}

There has been disagreement on which model for defining a ratio of diffuse radiation $\mathrm{H}_{\mathrm{d}}$ to daily global radiation $\mathrm{H}$ is appropriate for Thailand; the focus of the debate has been the clearness index $\mathrm{K}_{\mathrm{T}}$, defined as the ratio of $\mathrm{H}$ to daily extraterrestrial radiation $\mathrm{H}_{\mathrm{O}}$ (THA-S1, THA-S7). The ratio $\mathrm{H}_{\mathrm{d}} / \mathrm{H}$ is largely dependent on meteorological parameters other than $\mathrm{K}_{\mathrm{T}}$. The following model is preferred to the Liu and Jordan's, Linear $\mathrm{K}_{\mathrm{T}}$ and Collares-Pereira \& Rabl's models since it has lower root-mean square error (THA-S7):

$$
\mathrm{H}_{\mathrm{d}}=\mathrm{a}_{\mathrm{o}}+\mathrm{a}_{1} \mathrm{HK}_{\mathrm{T}}+\mathrm{a}_{3} \sin (360 \mathrm{~N} / 365+\mathrm{N})
$$

where:

$\mathrm{N}$ is the day of the year, $1-365$, $\mathrm{a}_{\mathrm{o}}, \mathrm{a}_{1}, \mathrm{a}_{3}$, and $\mathrm{N}$ are constants, determined to be $-9.161,2.630,-0.159$ and $-80^{\circ} \mathrm{C}$ respectively by KMITT at Bangkok.

The value of diffuse solar radiation is high in June, July, and August, and low in December, January, and February, with an annual mean of $2.33 \mathrm{kWhm}-{ }^{2}$ day- $^{1}$ (THA-S8).

PV water pumping technology is being promoted by the government of Thailand. Between 1991 and 1994, 350 PV pumping units have been installed in rural areas for irrigation and village water (THA-S4, THA-S5). Water is drawn from a 0.5 million $\mathrm{ft}^{3}$ reservoir. Such reservoirs are typical for rural Thailand. No comprehensive surveys and assessments of this resource have yet been undertaken (THA-S5). 


\section{Biomass Resources}

Thailand's potential in biomass is considered to be good. On a net heating value basis, sugarcane field residues cost $\$ 1.87 / \mathrm{GJ}$, while oil costs over $\$ 2.91 / \mathrm{GJ}$ when purchased at $\$ 19 / \mathrm{Bb} .1$ (THA-B1). The biogas potential is estimated at 17 million $\mathrm{m}^{3}$ (SE-N1).

Table of References for Thailand (see key following table for abbreviation and resource codes):

\begin{tabular}{|c|c|c|c|c|c|c|}
\hline Type of Analysis & Wind & Solar & Biomass & Geothermal & Hydro & General \\
\hline $\begin{array}{l}\text { Site-Specific } \\
\text { Analysis }\end{array}$ & & THA-S6 & & & & \\
\hline $\begin{array}{l}\text { Country-Wide } \\
\text { Surveys }\end{array}$ & & $\begin{array}{l}\text { THA-S2 } \\
\text { THA-S8 }\end{array}$ & & & & \\
\hline $\begin{array}{l}\text { Country-Wide } \\
\text { Maps }\end{array}$ & PRC-W10 & & & & & \\
\hline $\begin{array}{l}\text { Modeled Data } \\
\text { Sources }\end{array}$ & & $\begin{array}{l}\text { THA-S2 } \\
\text { THA-S6 } \\
\text { THA-S7 }\end{array}$ & & & & \\
\hline $\begin{array}{l}\text { Measured Data } \\
\text { Sources }\end{array}$ & SE-N1 & $\begin{array}{c}\text { THA-S2 } \\
\text { THA-S6 } \\
\text { SE-N1 } \\
\text { SE-S1 }\end{array}$ & & & & SE-N3 \\
\hline $\begin{array}{l}\text { Technology or } \\
\text { Economic } \\
\text { Assessment Only }\end{array}$ & THA-W1 & $\begin{array}{l}\text { THA-S4 } \\
\text { THA-S5 }\end{array}$ & $\begin{array}{l}\text { THA-B1 } \\
\text { SE-N1 }\end{array}$ & & & $\begin{array}{c}\text { THA-N1 } \\
\text { THA-N6 } \\
\text { THA-N7 } \\
\text { THA-N8 } \\
\text { SE-N3 }\end{array}$ \\
\hline
\end{tabular}

Key:

Abbreviations

Thailand $=$ THA

People's Republic of China $=$ PRC

South East Asia Region = SE $\underline{\text { Resources }}$

Wind $=\mathrm{W}$

Solar $=S$

Biomass $=\mathrm{B}$

Geothermal $=\mathrm{G}$

Hydro $=\mathrm{H}$

General $=$ N 


\section{The United States of America (US)}

\section{Wind Resources}

The most comprehensive source of information on wind energy resources in the United States of America (U.S.) is the Wind Energy Resource Atlas published in 1987 (US-W1). The atlas is based on information derived from National Weather Service measurements, which are not typically taken at the windiest sites, wind data from sites with high steady winds is generally not available. Also, wind resources, such as its turbulence characteristics, can vary significantly over small distances, particularly in very mountainous regions or in coastal or lake-shore regions. The availability of wind data taken in mountainous regions with extensive wind resources is much less than of data for more populated regions of the United States. For these reasons, the atlas also provides information on the certainty of the resource for each location.

The major source of wind data used in this atlas comes from the National Weather Service, which collects wind data from more than 800 sites. These measurements are collected by anemometers or wind vanes, usually at $10 \mathrm{~m}$ height or less. The airports are not normally located at the best wind energy sites and the anemometers are often on top of buildings that distort the wind field, so the available wind data is not considered the most reliable for wind resource assessment; this necessitates the use of other techniques to more accurately depict the distribution of these resources (US-N1).

Other data available for wind assessment includes wind measurements taken throughout the vertical depth of the atmosphere for weather purposes. Topographic and vegetative indicators, or numerical models can be used to estimate wind resources in the absence of measured wind data (US-W2).

In earlier studies for the United States, three separate assessments of the wind potential were analyzed by Elliott in 1979 (published in US-W3). From these assessments, a synthesized map of wind potential for a given height above the ground was developed.

In 1993, a comprehensive paper on wind potential in the United States was published (US-W4). This report includes detailed wind maps as well as an assessment of wind energy potential in the U.S. This paper is also available on-line through http://rredc.nrel.gov.

\section{Solar resources}

Continuous measurements of solar radiation in the United States were begun by the National Weather Service in 1951, in a network known as SOLRAD (SOLar RADiation). Until 1975, there were about 60 stations in the SOLRAD network (US-S8). All measured global horizontal solar radiation, although some measured only daily total energy. Because of a host of calibration and instrument problems, the measured data contained numerous errors. Therefore, after an evaluation conducted in the mid-1970s, only 26 stations were deemed suitable for inclusion in a national database of hourly values. The data from these stations, along with modeled values, was used to prepare the SOLar METeorological (SOLMET) database (US-S9) and the Solar Energy Resource Atlas of the United States (US-S10). Estimates of direct normal solar radiations can be found in tables developed by J.W. Clemons (US-S7) and in the Insolation Data Manual and Direct Normal Solar Radiation Data Manual (US-S2).

In 1981, funding became inadequate to support the SOLRAD network, and it gradually decayed until it was shut down in October 1985 for refurbishment. During this time, an improved tracker 
was developed and improved data recording equipment was installed at each station. In January 1988, the network resumed the collection of global horizontal and direct normal data at 27 sites selected for the upgraded network.

Of all the stations that participated in the National Weather Service SOLRAD network from 1951 to 1990, only 16 were active during the entire time the network was operational. As a result, information on long-term variability of solar resources is lacking. For most locations, there are fewer than 10 years of uninterrupted solar radiation data measurements. The short-term temporal characteristics of solar radiation data have been fairly well determined. Most of the data in the United States archives is hourly. Also, 1-minute data was recorded for a number of stations, providing more than adequate information on very short-term characteristics (US-N1).

Using the SOLRAD data (in particular, taking advantage of the higher-quality data collected in more recent years) and a new modeling approach, an updated, comprehensive assessment of solar resources in the United States was published by NREL in 1992 (US-S1). This is known as the National Solar Radiation Data Base (NSRDB). This database is derived from modeled as well as measured data to provide a 30-year (1961-1990) record of hourly global horizontal, direct normal, and diffuse solar resources at 239 stations in the United States. From this data, maps of solar resources have been prepared, and are now widely published. This data is also available on a CDROM that can be obtained from the National Climate Data Center in Asheville, NC. Data and maps are also available through the World Wide Web (US-S3).

Several technical data products have been developed using the NSRDB. Two solar radiation data manuals provide tables of information that can be applied to specific technologies, such as building design and flat-plate and concentrating collectors (US-S5, US-S6). Also, Typical Meteorological Years have been developed using the NSRDB, and are available in US-S4.

Among various reasons why the new NSRDB provides more accurate solar radiation values than the earlier SOLMET database are the following (US-S4):

- $\quad$ The NSRDB used an improved model for estimating values (more than $90 \%$ of the solar radiation data in both databases is modeled).

- The NSRDB offers more measured data, including direct normal radiation.

- $\quad$ The data was gathered using improved instrument calibration methods.

\section{Biomass Resources}

Data for a wide variety of biomass resources can be found on a web site created by NREL. The database is the Biomass Resource Information Center, and is available on http://rredc.nrel.gov. Additional publications on specific resources are described below.

\section{Forest and Agricultural Residues}

Recently, a biomass assessment was conducted for the Tennessee Valley region. A total of 1,110 million tonnes of standing forest biomass was inventoried. The total was subdivided into hardwood and softwood trees (US-B 1). This assessment does not include forest litter, lumber mill waste products, or agricultural biomass, and thus does not represent the total biomass resource base (US-N1). For the entire region, the total biomass of 1,110 million tonnes has an associated sampling error of $2.8 \%$. This assessment also estimated that 17 million tonnes or 0.56 metric 
tonne per acre of oven-dry energy wood (wood that is not designated for other uses) could be harvested in the Tennessee Valley each year (US-B1).

Another approach to biomass assessment is found in the Washington State Biomass Data Book (US-B2). Instead of attempting to inventory the total biomass resource, the authors have inventoried biomass residues and waste products, categorizing the biomass into agricultural, logging and lumber mill residues, MSW, wastes from secondary wood processing facilities, and biogas. Most of the agricultural residues in Washington come from grain harvests. The assessment estimates that 2.5 tons/acre (2.2 metric tons) should be left on dry land farms and 2 tons/acre (1.8 metric tons) on irrigated lands. This report identified several sources of forest residues, but focused on logging residues only. The quantity of forest residues available for energy applications depends on site-specific environmental and economic factors. Generally, mills have used their residues 'very efficiently, which consist of scrap wood, bark, and sawdust. They use it to meet their energy needs and sell the surplus (US-B2).

Both reports use very different techniques and therefore could not be used to compare biomass resources for these regions. The portion of biomass available for energy was estimated only on the basis that there were no competing demands (US-N1).

Various measurement methods of biomass energy are described in great detail in US-N1. The primary problem regarding biomass resource assessment is the lack of information on the accessibility and cost of biomass resources for energy use. Also, in order to obtain an accurate assessment of biomass resources for energy, a determination of the availability of land and water growing energy crops with respect to the demand for food, fiber, and timber that are or might be grown on the same land using the same water, is required. Similarly, there is a need to determine the demand for waste products for other uses (US-N1).

\section{Municipal Solid Waste}

The generation of MSW in the United States increased from 79 tonnes per year in 1960 to over 176 tonnes per year in 1990 (US-B6). At various locations throughout the United States, estimates of the per-capita rate vary from 0.8 to $4.2 \mathrm{~kg}$ per day (US-B3). Other estimates provide smaller ranges, from 1.5 to $2.8 \mathrm{~kg}$ per day (US-B2; US-B4; US-B5). Some of these solid wastes are combustible and are used as a renewable sources of energy in some regions (US-N1). In Washington state, 54 MWe was generated in 1991 (US-B2). MSW is being converted to electricity or steam heat by more than 100 facilities across the member economy (US-B5).

A community of 25,000 people could generate 45 tonnes of MSW per day, which is enough to produce approximately 1MWe continuously (US-B4). However, the actual energy production depends on the composition of waste products. The energy content varies from 2,000 Btu/pound $(4,652 \mathrm{kj} / \mathrm{kg}$ ) for food to $14,000 \mathrm{Btu} /$ pound $(32,564 \mathrm{kj} / \mathrm{kg})$ for plastics (US-B3).

Factors such as population, availability of landfills, the demand for thermal or electrical energy, and the general economy of the area determine the feasibility of using MSW for energy production. The methods used to convert MSW to energy include landfill disposal followed by collecting and burning the resultant methane, mass burning, and separating combustibles from other materials to produce a refuse-derived fuel (RDF). RDF can be converted into electricity through anaerobic digestion, hydrolysis and fermentation, pyrolysis, and cofired burning with another fuel such as natural gas. Among these methods, some are more environmentally desirable, the least of which is mass burning of MSW without separating the combustibles (US-Nl). 
The determination of MSW resources for individual municipalities requires measurements of the MSW at the dump site or the point of generation (US-N1). However, measuring the composition of MSW is a much more costly process. There is also no standard method for collecting such data and no general agreement on the categories to be used to define MSW (US-B7).

\section{Geothermal Resources}

A comprehensive study of the member economy's geothermal resources can be found in an assessment done in 1978 (US-G2).

Geothermal resources occur in a variety of geologic environments, but are most commonly found in volcanically active or fault-dominated regions. Most geothermal resources have been located from observations of surface phenomena, such as geysers, fumaroles, and hot springs (US-N1). For example, the methods used in connection with the discovery of the Desert Peak geothermal field in Nevada are described by Benoit et al. (US-G1).

For electricity production, the most valuable geothermal fields yield naturally occurring steam, not hot or warm water. In the hyperthermal regions of the western United States these types of geothermal basins are rare. There are only three known vapor-dominated systems: the Lassen system in California, the Mud Volcano at Yellowstone, and the Geysers system north of San Francisco. The first two lie within the member economy's National Park systems, and are therefore not exploitable. The Geysers system's energy has been used since the 1960s. This resource can supply $15 \mathrm{PJ} /$ year for 100 years (US-G2 as referenced in US-N2). In contrast, hot water geothermal fields are found in many areas of the United States. Fields that produce water at temperatures higher than $150^{\circ} \mathrm{C}$ provide an estimated $198 \mathrm{PJ}$ of electricity for 100 years. Even though the electricity production from steam and hot water was only 19 PJ in 1979, it represents only a small fraction of the total estimated resource. Also, many fields are yet to be discovered. Further exploration is expected to provide $1183 \mathrm{PJ}$, not including the hot dry rock energy (US-N2).

\section{Hydro Resources}

The major source of United States developed and undeveloped hydropower resource information can be found in documents produced by the Federal Energy Regulatory Commission (FERC) (US-H5).

In order to estimate the hydro resource, the summary tables provided by Moreira and Poole may be used (US-H1). They show the total estimated hydropower resource to range from 36,000 to 44,000 TWh (terawatt-hours; $1 \mathrm{TW}-1,000 \mathrm{MW}$ ). The exploitable potential is estimated at 15,090 TWh. The Worldwatch Institute's estimate of the total resource is 73,000 TWh and the exploitable potential is somewhat higher than that provided by US-H2. The estimated hydropower production is $1,300 \mathrm{TWh}$ (op cit.), or $8.6 \%$ of the smallest exploitable resource estimate. The estimate is subject to vast uncertainties, however. They stem from the fact that these estimates are derived by taking the "energy contained in precipitation falling on the surface of the United States as it drops to the sea, minus water taken off by consumption and lost to evaporation. The mass of the water times the average elevation drop yields the energy potential in the falling water" (US-H3).

To estimate the hydropower resources for a given river basin or catchment area, three sources of information can be used: hydrographic records, which define the rate of flow of water at a certain point within the river basin, measurements or estimates of precipitation falling on the catchment area, and the topographic characteristics of the catchment basin. Hydrographic stations have been in operation in the United States since the late 1800s. There is approximately one station for 
every $1,000 \mathrm{~km}^{2}$ in north America. The density of rain gages is one station per every $1,220 \mathrm{~km}^{2}$ (US-H4).

In complex terrain, rainfall can vary, and because the density of rainfall measurements is often less in mountainous terrain than in flatter country, estimates of the total volume of precipitation over a river basin in mountains can be less certain than in flatter country (US-Nl).

In order to develop a national hydropower survey, an extensive resource assessment program for hydropower resources was initiated in 1991. The program is based upon the computerized Hydroelectric Model, which uses the FERC data as an input and takes into account various legal, institutional, and environmental aspects (US-H6).

The overall North American (including the economies of Canada, the United States, and Mexico) hydro resource is considered to be enormous because of various meteorological and topographical factors: 300 times larger than of the United Kingdom (US-N2). For example, US-N2 lists North American rivers in order of their rates of flow, and shows that the largest is the Mackenzie River at $7340 \mathrm{~m}^{3 /} \mathrm{s}$, which consequently has the largest gross hydro energy potential of $3570 \mathrm{PJ}$ (US-N2). 
Table of References for the United States of America (see key following table for abbreviation and resource codes):

\begin{tabular}{|c|c|c|c|c|c|c|}
\hline Type of Analysis & Wind & Solar & Biomass & Geothermal & Hydro & General \\
\hline $\begin{array}{l}\text { Site-Specific } \\
\text { Analysis }\end{array}$ & US-N2 & & $\begin{array}{l}\text { US-B1 } \\
\text { US-B2 }\end{array}$ & $\begin{array}{l}\text { US-G1 } \\
\text { US-G2 } \\
\text { US-N2 }\end{array}$ & & \\
\hline $\begin{array}{l}\text { Country-Wide } \\
\text { Surveys }\end{array}$ & $\begin{array}{l}\text { US-W4 } \\
\text { US-N1 } \\
\text { US-N2 }\end{array}$ & $\begin{array}{l}\text { US-S1 } \\
\text { US-S2 } \\
\text { US-S4 } \\
\text { US-S7 } \\
\text { US-N1 } \\
\text { US-N2 }\end{array}$ & $\begin{array}{l}\text { US-B3 } \\
\text { US-B6 } \\
\text { US-N1 } \\
\text { US-N2 }\end{array}$ & $\begin{array}{l}\text { US-G2 } \\
\text { US-N1 } \\
\text { US-N2 }\end{array}$ & $\begin{array}{l}\text { US-H3 } \\
\text { US-H5 } \\
\text { US-H6 } \\
\text { US-N1 } \\
\text { US-N2 }\end{array}$ & $\begin{array}{l}\text { US-N1 } \\
\text { US-N2 }\end{array}$ \\
\hline Country-Wide Maps & $\begin{array}{l}\text { US-W1 } \\
\text { US-W2 } \\
\text { US-W3 } \\
\text { US-W4 } \\
\text { US-N2 }\end{array}$ & $\begin{array}{c}\text { US-S3 } \\
\text { US-S10 } \\
\text { US-S11 } \\
\text { US-N2 }\end{array}$ & US-N2 & $\begin{array}{l}\text { US-G2 } \\
\text { US-N2 }\end{array}$ & US-N2 & US-N2 \\
\hline $\begin{array}{l}\text { Modeled Data } \\
\text { Sources }\end{array}$ & US-N1 & $\begin{array}{l}\text { US-S1 } \\
\text { US-S2 } \\
\text { US-S4 } \\
\text { US-S7 }\end{array}$ & & & & \\
\hline $\begin{array}{l}\text { Measured Data } \\
\text { Sources }\end{array}$ & $\begin{array}{l}\text { US-W1 } \\
\text { US-W2 } \\
\text { US-W4 }\end{array}$ & $\begin{array}{c}\text { US-S1 } \\
\text { US-S2 } \\
\text { US-S4 } \\
\text { US-S7 } \\
\text { US-S9 } \\
\text { US-S11 }\end{array}$ & $\begin{array}{l}\text { US-B } \\
\text { US-B4 } \\
\text { US-B5 }\end{array}$ & & $\begin{array}{l}\text { US-H1 } \\
\text { US-H2 } \\
\text { US-N2 }\end{array}$ & \\
\hline $\begin{array}{l}\text { Technology or } \\
\text { Economic } \\
\text { Assessment Only }\end{array}$ & $\begin{array}{l}\text { US-W3 } \\
\text { US-N2 }\end{array}$ & $\begin{array}{l}\text { US-S5 } \\
\text { US-S6 }\end{array}$ & US-B7 & & US-H4 & \\
\hline
\end{tabular}

Key:

$\underline{\text { Abbreviations }}$

United States of America $=$ US
Resources

Wind $=\mathrm{W}$

Solar $=S$

Biomass $=\mathrm{B}$

Geothermal $=\mathrm{G}$

Hydro $=\mathrm{H}$

General $=\mathrm{N}$ 


\section{Appendix A: Bibliography (Economies are presented in same order as in text)}

\section{Australia (AUS)}

\section{Biomass}

1. Godfrey, B. 1995. "Energy from Waste-Options for the Future," in Waste Management and Recycling. Proceedings of the Conference on Waste Management and Recycling, Sydney, Australia, 26-27 June, pp. 1-5. Report no. CONF-9506274. Available from Energy Research and Development Corp., GPO Box 629, Canberra, ACT Australia 2601.

2. Mendelsohn, R. and K. Sweeney. 1994. Biomass in the Energy Cycle Study. Part IMain Report. Report no. ERDC-234, ISBN: 0-642-19103-4. Available from Energy Research and Development Corp., GPO Box 629, Canberra, ACT Australia 2601.

\section{General}

1. Ershevich, V.V. 1992. "Power Generation in Australia," Ehnergokhoziaistvo za Rubezhom (USSR) vol. 1, pp. 22-23.

2. Outhred, H. 1992. "The Role of Renewable Energy Sources and Nuclear Energy in Electricity Generation," in Australia's Greenhouse Policy Seminar, No. 92/8, pp. 83-94. ISBN: 0-85825-569-3. Available from Institution of Engineers, Australia, Barton, ACT (Australia).

3. University of New South Wales. 1995. Seventeenth Annual Report. Energy Research, Development and Information Centre (ERDCI). Sydney, Australia, 101 pages. ISSN: 01578502. Available from ERDIC, University of New South Wales, Sydney, NSW 2052, Australia.

4. Hoy, R.D.; B.K. Smith; P. Van Der Riet; A.D. McCowan; and R. Tyshing. 1997 "Wave Energy Potential of the Victorian Coast," AIJ Australian Office -- FAX, May 05, pp. 1-10.

5. Stevens, M. 1996. "Renewable Energy R\&D and Technology Transfer-Australian Development," in Proceedings of APEC Energy R\&D and Technology Transfer and Renewable Energy Resource Assessment Seminar, Beijing, China, February. pp. 48-54.

\section{Geothermal}

1. Burns, K.L.; R.A. Creelman; N.W. Buckingham; and H.J. Harrington. 1995. "Geothermal Development in Australia," in World Geothermal Congress: Worldwide Utilization of Geothermal Energy. Los Alamos National Laboratory LA-UR-95-775, pp. 18-31.

2. Somerville, M.; D. Wyborn; P. Chopra; S. Rahman; D. Estrella; and T. Van der Meulen. 1994. Hot Dry Rock Feasibility Study. Report no. ERDC-243, ISBN: 0-642-19113. Available from: Energy Research and Development Corp., GPO Box 629, Canberra ACT Australia 2601. 


\section{Hydro}

1. Causon, G.J.; D.E. Clarke; and D.P. Roberts. 1993. "The Environment for Hydro Power in Australia," in Hydropower, Energy and the Environment: Options for Increasing Output and Enhancing Benefits. Paris, France: Organization for Economic Co-Operation and Development, pp. 337-349. ISBN: 92-64-14075-1.

\section{Solar}

1. Bureau of Meteorology. 1992. “Observations and Engineering Plans.” July.

2. Hutchinson, M.F.; T.H. Booth; J.P. McMahon; and H.A. Nix. 1984. "Estimating Monthly Mean Values of Daily Total Radiation for Australia," Solar Energy 32(2), pp. 277-290.

3. Kerr, S. 1994. "Solar Takes a Commercial Route," Australian Environmental Review 9(10), pp. 6-7. November.

4. Morrison, G.L. and A. Litvak. 1988. "Condensed Solar Radiation Data Base for Australia." The University of New South Wales School of Mechanical and Industrial Engineering. Report \#1988/FMT/1. March.

5. Forgan, B.W. 1997. "Bureau of Meteorology/Solar Exposure Monitoring System," AIJ Australian Office-FAX, May 05, pp. 11-16.

\section{Wind}

1. Dear, S. 1990. "Western Australian Wind Atlas," Sunworld 14(2), pp. 53-54.

2. Dear, S.J.; T.J. Lyons; and M.J. Bell. 1991. "Wind Energy Assessment under Strong Mesoscale Forcing," Solar Energy 56(1), pp. 59-62.

3. Lyons, T.J. and M.J. Bell. 1990. "Mesoscale Variations in Available Wind Power Potential," Solar Energy 45(3), pp. 149-166.

4. Morgan, V.T. 1995. "Statistical Distributions of Wind Parameters at Sydney, Australia," Renewable Energy 6(1), pp. 39-47. 


\section{Brunei Darussalam (BD)}

\section{General}

1. The Europa Handbook. 1997. "Brunei Darussalam. Statistical Survey.” Europa Publications Limited, Vol. 1, ISBN 1-85743-033-6.

2. BN/BX: Brunei. 1997. “Geography; Economy.” Available through: http://www.adfa.oz.au/CS/flg/wf93/bx.html.

3. 1997. "Nations of the Commonwealth: Brunei Darussalam," Available through: http://www.tbc.gov.bc.ca/cwgames/country/Brunei/brunei.html.

4. 1997. "Brunei Darussalam; Background Notes for Brunei," Available through: gopher://emailhost.ait.ac.th:70/00.../Background\%20Notes\%20for\%20Brunei.

\section{Hydro}

1. Afshar, Y. and R.W. Kwiatkowski. 1990. "Development of a Major Hydroelectric Project in the Pacific Rim," in Power-Gen '90: 3rd International Power Generation Industries Conferences and Exhibition. Orlando, FL, 4-6 December, pp. 201-208.

\section{Solar}

1. Malik, A.Q. and S. Hjtamam. 1995. "Estimation of Monthly Average Daily Diffuse Radiation for Brunei Darussalam," Renewable Energy 6(4), pp. 425-427.

2. Malik, A.Q. and B.H. Hamid. 1996. "Development of a Solar Cooker in Brunei Darussalam," Renewable Energy 7(4), pp. 419-425.

3. Wernstedt, F.L. 1972. “World Climatic Data," Climatic Data Press, p. 356. 


\section{Canada (CDA)}

\section{Biomass}

1. Alemdag, I.S. and J. Richardson. 1993. Annotated Bibliography of ENFOR Biomass Reports 1979-1990. Report no. CFS/HQ-ST-X-6. Available from PC Petawawa National Forestry Inst., Distribution Centre, P.O. Box 2000, Chalk River, ON, CAN K0J 1 J0.

2. Cochrane-SNC-Lavalin. 1994. Assessment of the Potential Use of Biomass Resources as a Sustainable Energy Source in Saskatchewan. Report no. MIC-95-01809/XAB. Available from NTIS.

3. Duff, S.J.B; J.A. Barclay; E.N. Hogan; and G.S. Carisse. 1992. "Biomass Conversion Technologies: The Research and Development Activities of Energy, Mines and Resources Canada," in Energy from Biomass and Wastes XVI. Proceedings of the Annual Conference on Energy from Biomass and Wastes, Orlando, FL, 2-6 March, pp. 115-137. Report no. CONF-920348. Available from the Institute of Gas Technology, 3424 South State Street, Chicago, IL 60616.

\section{General}

1. British Columbia Energy Council. 1993. Renewable Energy in British Columbia: An Overview. Report No. BCEC-94-02587. Available from PC B.C. Legislative Library, Government Documents Div., Parliament Bldg., Victoria, BC, Canada V8V $1 X 4$.

2. Diener and Associates. 1993. The Potential for Non-Utility Generation in the Province of Ontario. Synthesis Report. Report no. SGDA-CE04621. Available from IPPSO, Box 1087, Station 7, Toronto, ON, CAN M4Y 2 T7.

3. Izsak, G.L.; B.M. Guthrie; and T.L. Birkenheier. 1992. "Non-Conventional Generation Technologies and the Canadian Renewable Energy Program," in Be Part of the Process: Planning Our Electric Future Now, pp. 43-53. Report No. CEA-CE04417. Available from Canadian Electrical Association, One Westmount Square, Ste. 1600, Montreal, PQ, Canada H3Z 2 P9.

4. Saskatchewan Energy Conservation and Development Authority. 1994. Renewable Energy Potential in Saskatchewan: An Assessment of Resources. Report no. MIC-95-04108/XAB. Available from NTIS.

5. Dolenko, A.; R. Godin; D. Hetherington. 1996. "The Current Status -and Technological Development of Renewable Energy in Canada," in Proceedings of APEC Energy R\&D and Technology Transfer and Renewable Energy Resource Assessment Seminar, Beijing, China, February, pp. 48-56.

6. Saskatchewan Energy and Mines. 1994. "Energy Sources and Fuels in Saskatchewan: Prosperity Through Diversity," A Technical Report, December.

7. Environment Canada 1985 "Canadian Weather Trivia Calendar," Minister of Supply and Services Canada. 


\section{Geothermal}

1. Arkay, K. 1993. 1st Springhill Geothermal Energy Conference, Springhill, Nova Scotia, 28-29 October 1992. Report no. GSC/ISPG-2773. Available from PC Geological Survey of Canada, Publications Distribution, 601 Booth Street, Ottawa, ON, CAN K1A 0E8.

2. Ghomshei, M.M.; T.L.S. Brown; and J.M. MacRae. 1992. "Geothermal Prospects in British Columbia: Resource, Market, and Regulatory Aspects," in Transactions, vol. 16, 20th anniversary. Proceedings of Geothermal Resources Council Annual Meeting, San Diego, CA, 4-7 October, pp. 57-63. Available from Geothermal. Resources Council, P.O. Box 1350, Davis, CA 95617.

\section{Hydro}

1. Barnes, M.J.; L. Eden; and C. Vansant. 1991. "Hydropower: Making Its Mark in North America," Hydro Review 10(4), pp. 12-20.

2. Kier, G. 1991. "Aberfeldie Expansion: A Resource Smart Development," in Proceedings of the 10th Canadian Hydrotechnican Conference and Engineering Mechanics Symposium, Vancouver, Canada, 29-31 May. Report no. CSCE-CE04388, ISBN: 0-921303-23-8. Available from Canadian Society for Civil Engineering, 2050 Mansfield St., Suite 700, Montreal, PQ, CAN H3A 1 Z2.

3. Wiebe, P.A. 1994. Electricity '94: A New Energy Order: Home Grown Hydro, the Key to Regional and International Business Expansion. Montreal: Canadian Electrical Association. Report no. MIC-94-06514/XAB. Available from NTIS.

\section{Solar}

1. Canadian Climate Program. 1982. Canadian Climate Normals 1951-1980, vol. 1.

2. Environment Canada and Atmospheric Environment Service. 1978. Solar Radiation Data Analyses for Canada 1967-1976, vol. 1: The Atlantic Provinces.

3. Environment Canada, Atmospheric Environment Service, and The National Research Council of Canada. 1993. Canadian Weather Energy and Engineering Data Sets and Canadian Weather for Energy Calculations. Software Users Manual.

4. Garrison, J.D. 1994. "Evaluation of the Effect of Volcanic Eruption on the Solar Radiation at Six Canadian Stations," in SOLAR '94 Technical Papers, S.M. Burley, M.E. Arden, R. Campbell-Howe, and B. Wilkins-Crowder, eds. Boulder, CO: American Solar Energy Society, pp. 339-343. ISBN: 0-89553-166-6. Available from American Solar Energy Society, 2400 Central Ave., Ste. G-1, Boulder, CO.

5. Garrison, J. and K. Sahami. 1993. "Analysis of Clear Sky Solar Radiation for Seven Canadian Sites," in Proceedings of SOLAR '93. American Society of Mechanical Engineers and American Solar Energy Society joint solar energy conference. Boulder, CO: American Solar Energy Society, pp. 445-450. ISBN: 0-89553-165-8.

6. Hooper, F.C.; C.R. Attwater; A.P. Brunger; J.A. Davies; J.E. Hay; D.C. McKay; and T.K. Won. "The Canadian Solar Radiation Data Base." Presented at the ASHRAE meeting, Detroit. 
7. Morris, R.J.; A.P. Brunger; and D. Thevenard. 1992. "A Solar and Building Energy Digital Resource Atlas for Canada," in Renewable Energy: Technology for Today. Annual Conference of the Solar Energy Society of Canada. Ottawa, ON: Solar Energy Society of Canada Inc., pp. 123-130. Report No. SESC-CE04252. Available from Solar Energy Society of Canada, 420-301 Moodie Drive, Suite 420, Nepean, ON, Canada K2H 9C4.

8. McKay,D.C. andR.D. Morris. 1985. "SolarRadiationDataAnalyses for Canada 1967-1976," A Publication of the Canadian Climate Program, Environment Canada.

\section{Wind}

1. Hughes, L. and S. Scott. 1992. "The Potential for Wind Energy in Atlantic Canada," in Renewable Energy: Technology and the Environment, Proceedings of the 2nd World Renewable Energy Congress, Reading, UK, 13-18 September. New York: Pergamon Press, vol. 3, pp. 1567-1572.

2. Salmon, J. "Wind Energy in Southwest Alberta (WESWA)," in Proceedings of the Ninth Annual National Conference of the Canadian Wind Energy Association. Ottawa, ON: Canadian Wind Energy Association, pp. 263-283. Report No. CANWEA-95-00065. Available from PC CanWEA, Suite 205, 2415 Holly Lane, Ottawa, ON, Canada K1V 7P2. 


\section{Chile (CHL)}

\section{General}

1. Anon. 1994. "Chile: Country Profile," Energy Utilities, September, pp. 36-37.

\section{Solar}

2. Alcayaga, O. 1985. "Solarimetry at the Coast in Atacama Desert, Chile (Antofagasta)," presented at the 77th Miami International Conference on Alternative Energy Sources, 911 December, Miami Beach, FL.

3. Dobosi, Z. and P. Ulriksen. 1970. "Distribution of Global Radiation over Chile," in International Solar Energy Society Conference, 2-6 March, Melbourne, Australia. Victoria, Australia: Australian and New Zealand Section of the Solar Energy Society, pp. $1-6$.

4. Hirschmann, J. 1973. "Records on Solar Radiation in Chile," Solar Energy vol. 14, pp. 129-138.

5. Hirschmann, J.R. 1976. "Mathematical Approximative Equations for Solar Radiation Incidental to a Determined Site," in Proceedings of the Unesco/World Meteorological Organization Symposium, pp. 198-209. 30 August-3 September. Solar Energy Research Institute, Solar Energy Information Center.

6. Sarmiento, P. and F. Lira. "Modeling Monthly Incident Solar Radiation on Inclined Surfaces for Chilean Locations." Technical Note.

\section{Wind}

1. Nelson, V.; M.E. Caldera; and W. Palz. 1984. "Wind Energy Potential and Wind Projects in Latin America," in European Wind Energy Conference 23 October, Hamburg, Germany. London: H.S. Stephens and Associates, pp. 945-950.

2. Ruttlant, J. 1994. Modeling the Day to Day Wind Variability Offshore Central Chile at about 30 deg. South. Order No. DE95606032. Available from OSTI, NTIS.

3. Tironi, E. 1990. "Prospects for Wind Energy Development in Participating Countries," in Wind Energy Applications and Training Symposium, Final Report, p. 10. Report no. CONF- 9009334-Summ. Order No. TI91006703. Available from OSTI; NTIS.

4. $\quad$ Schaefer, J.C.; R. Zuleta. 1993. "Wind Power Opportunities in Chile," Windpower' 93. 


\section{People's Republic of China (PRC)}

\section{Biomass}

1. Perlack, R.D. 1995. "Determination of the Potential Market Size and Opportunities for Biomass-to-Electricity Projects in China," in Proceedings of the Second Biomass Conference of the Americas, Portland, OR, 21-24 August, pp. 49-54. Golden, CO: National Renewable Energy Laboratory. Report no. NREL/CP-200-8098. Available from OSTI.

\section{General}

1. Fengqi, Z. 1994. "Today's Situation and Prospects for China's Electric Power Industry," Power Generation Technology (UK) pp. 27-30. ISSN: 0957-1361.

2. Qui, D. 1990. "The Role of Renewable Energy in Rural Development in China: Achievements and Prospects," in Energy for Rural Development. Proceedings of the Meeting of the United Nations Group of Experts on the Role of New and Renewable Sources of Energy in Integrated Rural Development, Stockholm, Sweden, 22-26 January, pp. 155-174. London: Zed Books Ltd. ISBN: 1-85649-037-8.

3. Wenlien, L. 1991. "The Development of Indigenous Resources for Electricity in China," Power Generation Technology 1990-1991, pp. 41-45.

4. Xuemin, C. 1992. "Tibet: A Mixed Bag of Energy Resources," Modern Power Systems, May, pp. 31-32.

5. Zhen, F. 1994. "Rural Energy Resources: Applications and Consumption in China," Energy Sources, vol. 16, pp. 229-239.

6. Zhenming, Z. and G. Suhua. 1994. "Position of New and Renewable Energy in the Energy System of China," Int. J. Solar Energy, vol. 14, pp. 89-98.

7. "China: Renewable Energy for Electric Power." 1996. Document of the World Bank, Report No. 15592-CHA, September 11.

\section{Geothermal}

1. Ji-Yang, W.; C. Moxing; X. Liang-ping; and P. Zhong-he. 1992. "Geothermal Systems in Continental Area of China," in Water-Rock Ineraction: Proceedings, Park City, UT, 9-23 July, pp. 1371-1374. Report no. CONF-920671-Vol. 2. Available from A.A. Balkema Publishers, Old Post Road, Brookfield, VT 05036.

\section{Solar}

1. Newland, F.J. 1989. "A Study of Solar Radiation Models for the Coastal Region of South China," Solar Energy 43(4), pp. 227-235.

2. Qun, Z. 1994. "Recent Decreasing Trend of Solar Radiation and Its Effect on Summer Monsoon Rainfall of Eastern China," in World Resource Review 6(4), pp. 535-544. ISSN: 1042-8011. 
3. Wenxian, L. and L. Enrong. 1992. "Annual and Seasonal Global Solar Radiation Climates in Yunnan, China," Energy Convers. Mgmt. 33(11), pp. 1021-1029.

4. Yinqiu, M.; Q. Yuliang; and Shixibao. 1994. "Present Status of Project Development of Photovoltaic System in Western China and Strategy for Promoting PV Market in Western China," in Proceedings of ENERGEX '93 vol. 3, pp. 43-49. Report no. CONF-9310173.

5. Guangzhaom, Z.; W. Yu; Y. Luguang; D. Keyun; G. Bao; H. Dexin; L. Hongxun; L. Zhengui; R. Xiang; S. Dinghuan; W. Buxuan; Y. Xiaoming; Z. Fenggi; Z. Yajile; Z. Tieyong (China Solar Energy High-Level Expert Committee) 1995. Prepared on the basis of the country report "Solar Energy in China" for the High-Level Expert Meeting of the World Summit Process in Paris June 1993 with some corrections and new data. Beijing, China.

6. Guang, C.R.; H.J. Jun. 1990. "Present and Future Status of Utilization of Photovoltaics in People's Republic of China," in Energy and the Environment into the 1990s, vol. 1. Proceedings of the First World Renewable Energy Congress, 23-28 September, Reading, UK. Oxford: Pergamon Press, pp. 213-220.

7. Wenxian, L. 1988. “A General Correlation for Estimating the Monthly Average Daily Direct Radiation Incident on a Horizontal Surface in Yunnan Province, China," in Solar Energy 41(1), pp. 1-3

8. Wenxian, L. 1989. "General Correlation for Estimating the Monthly Total and Direct Radiation Incident on Horizontal Surfaces in Yunnan, China," in International Journal of Energy Research, vol. 13, pp. 589-593

9. Yongfen, W. "The Development of Small Wind-Solar Generating Systems in China," in Wind Engineering 19(1), pp. 17-19

10. Bin-zhong, W. 1983. "Solar Energy Resources and Their Classification," Rural Energy Planning in China and Other Developing Countries of Asia, RAO Environment and Energy Paper \#5, 1985, Rome (Technical Papers Presented at the Workshop on Rural Energy Planning in the Developing Countries of Asia, Beijing, April 11-12.

\section{Wind}

1. Abudukelimu, A.; H. Ishitani; K. Yamada; and R. Matsuhashi. 1994. "Evaluation on Energy Production by Utilizing Deserts Effectively and $\mathrm{CO}_{2}$ Reducing Measures." Presented at the Meeting of Japan Society of Energy and Resources, 13-14 April, Osaka, Japan, pp. 39-42.

2. Gongren, X. and D. Huizhu. 1990. "The Development and Prospects of Wind Power Generating in China," in Energy and the Environment into the 1990s, vol. 3. Proceedings of the World Renewable Energy Congress, 23-28 September, Reading, UK. Oxford: Pergamon Press, pp. 1653-1659. ISBN: 0-08-037539-1.

3. Huizhu, D.;X. Gongren; and X. Changjun. 1992. "The Strategic Development Plan of Wind Power Generation in China," in Renewable Energy Technology and the Environment, Proceedings of the 2nd World Renewable Energy Congress, 13-18 September. New York: Pergamon Press, vol. 3, pp. 1684-1688. 
4. Huizhu, D. and J. Twidell. 1988. "Brief Review of Wind Energy Exploitation in China," Wind Eng. 12(5), pp. 292-301.

5. Pengfei, S. 1993. "Activities of the Regional Working Group on Wind Energy (RWGWE) in Asia and the Pacific," in ENERGEX 93:5 International Energy Conference. Taejon, Korea: KIER, pp. 239-247.

6. Yang, M.F. 1988. "Collection and Power Spectrum Analysis of Instantaneous Wind Speed from 134-Meter Height Tower in Xilin-Haote, Nei-Mong, China," in The 8th Miami International Conference on Alternative Energy Sources, vol. 1-2. Coral Gables, FL: Clean Energy Research Institute University of Miami.

7. Zhinan, C. and C. Xiaoyao. 1988. "The Wind Power Resource and Its Development Potential in Fujian Province," Wind Engineering 12(2), pp. 118-124.

8. "Feasibility Study of Small-Scale Wind-PV Hybrid Systems for Individual Households in Inner-Mongolia" 6.12 1996. China-America Cooperation Project, Institute of Policy and Management, Chinese Academy of Science, New Energy Leading Group of Inner-Mongolia Government.

9. “ANNEX 1: Status of Wind Power. I. Wind Resources.” Internal World Bank Report.

10. Pengfei, S. 1996. "Wind Resources in Some Asia \& The Pacific Countries and Wind Power Development in China," in Proceedings of APEC Energy R\&D and Technology Transfer and Renewable Energy Resource Assessment Seminar, Beijing, China, February. pp. 173-187. 


\section{Hong Kong, China (HKC)}

\section{General}

1. Chou, W.L. 1984. "Energy in the ESCAP Region: Policies, Issues, and the Potential for Regional Co-Operation," in Development Papers No. 4. New York: United Nations Sales Section, pp. 37-52.

2. Mackenzie, G.; R. Eastwood; and L. Do. 1993. "Power to the People," World Coal, January, pp. 24-28, 30-34.

\section{Solar}

1. Chung, T.M. 1992. "A Study of Luminous Efficacy of Daylight in Hong Kong," Energy and Buildings vol. 19, pp. 45-50.

2. El-Adawi, M.K.; M.M. El-Niklawi; A.A. Kutub; and G.G. Al-Barakati. 1996. "Estimation of the Hourly Solar Irradiance on a Horizontal Surface," Solar Energy 36(2), pp. 129-134.

3. Leung, C.T. 1980. "The Fluctuation of Solar Irradiance in Hong Kong," Solar Energy vol. 25, pp. 485-494.

4. Yeung, M.R.; P.K. Yuen; A. Dunn; and L.S. Cornish. 1992. "Performance of a Solar-Powered Air Conditioning System in Hong Kong," Solar Energy 48(5), pp. 309319.

5. Lam, J.C.; and D.H. W. Li. 1996 "Study of Solar Radiation Data for Hong Kong," Energy Conversion Management, Vol. 37, No. 3, pp. 343-351.

6. Close, J. 1996. "The Integration of Photovoltaics within High Rise Buildings in the Dense Urban Environments of SE Asia, Consideration of Legislation to Promote It and Maintain Solar Energy Access," Renewable Energy, vol. 8, 1-4, pp. 471-474, May. 


\section{Indonesia (INA)}

\section{Biomass}

1. Choong, E.T.; R. Atmawidjaja; and S.S. Achmadi. 1993. "The Forest Products Industry in Southeast Asia: An Emphasis on Indonesia," Forest Products Journal, May, pp. 44-52.

\section{General}

1. Arismunandar, A. 1993. "The Need for Increased Renewable Energy Use in Indonesia: Growth in Electricity Demand, Remote Island Application and Environmental Concerns," keynote address delivered at the workshop REPSO-INDONESIA, Opportunities for Renewable Energy Development in Indonesia, Jakarta, 17-18 November.

2. Notodisuryo, E.U. and A.J. Surjadi. 1989. "Efforts to Develop and Implement Regional Energy Planning in Indonesia," in 14th Congress of the World Energy Conference. Montreal, 17-22 September, pp. 1-16.

3. Rozali, R. and S. Albright. 1992. "Sustainable Development in Indonesia: A Renewable Energy Perspective," in Renewable Energy: Technology and the Environment. Proceedings of the 2nd World Renewable Energy Congress, Reading, UK, 13-18 September, pp. 2568-2572.

4. Vitale, R.L. 1994. “Indonesian Intricacies," Independent Energies, July-August, pp: 2933.

\section{Geothermal}

1. Ganda, S.; D. Sunaryo; D. Hantono; and T. Tampubolon. 1992. "Exploration Progress of High Enthalpy Geothermal Prospect in Indonesia," in Transactions, vol. 16, 20th anniversary. Proceedings of the Geothermal Resources Council Annual Meeting, San Diego, CA, 4-7 October, pp. 83-88. Report no. CONF-921083. Available from Geothermal Resources Council, 2001 Second Street, Suite 5, PO Box 1350, Davis, CA 95617.

2. Mahon, T.; S. Modjo; and V.T. Radja. 1992. "The Results of a Joint Scientific Study of the Flores Ulumbu Geothermal Area," in Transactions, vol. 16, 20th anniversary. Proceedings of the Geothermal Resources Council Annual Meeting, San Diego, CA, 4-7 October, pp. 97-104. Report no. CONF-921083. Available from Geothermal Resources Council, 2001 Second Street, Suite 5, PO Box 1350, Davis, CA 95617.

3. Aryawijaya, R. 1996 "Status of Geothermal Resource Development and Future Outlook in Indonesia," in Proceedings of APEC Energy R\&D and Technology Transfer and Renewable Energy Resource Assessment Seminar, Beijing, China, February. pp. 214-226.

\section{Solar}

1. Morrison, G.L. and Sudjito. 1992. "Solar Radiation Data for Indonesia," Solar Energy 49(1), pp. 65-76. 


\section{Wind}

1. Flowers, L. 1993. Trip Report to Jakarta, Indonesia. Golden, CO: National Renewable Energy Laboratory. DOE/FTR-94006518.

2. Panggabean, L.M. 1990. "Prospects for Wind Energy Development in Participating Countries: Indonesia," in Wind Energy Applications and Training Symposium, San Francisco, 19-28 September. Order no. TI91006703, available from OSTI, NTIS. 


\section{Japan (JPN)}

\section{General}

1. Kidehashi, T. 1993. "Development of New Energy Sources: Current Status and Challenges," in New Electricity 21: Power Industry Technology and Management Strategies for the Twenty-First Century. Proceedings of the International Energy Agency International Conference on Power Industry Technology and Management Strategies for the 21st Century, Tokyo, Japan, 12-14 May 1992, pp. 449-454. Paris: OECD/IEA. ISBN: 92-64-14073-5.

2. Kidahashi, T. 1994. "Advanced Renewable Energy Technologies in the Future," in IEA International Conference on Technology Responses to Global Environmental Challenges: Energy Collaboration for the 21st Century. Kyoto, Japan, 6-8 November 1991, pp. 461468.

3. Energy and Industrial Technology Development Organization. 1993. Research and Development Plans for FY 1993. Report no. NEDO-OS-9301-1. Order no. DE94791344. Available from OSTI.

4. Miyazawa, K. "Renewable Energy Technology in Japan," in Proceedings of APEC Energy R\&D and Technology Transfer and Renewable Energy Resource Assessment Seminar, Beijing, China, February.

\section{Geothermal}

1. Agency of Industrial Science and Technology. 1992. Japan's Sunshine Project. Report no. ETDE/JP-mf-93768268. Order no. DE93768268. Available from OSTI, NTIS.

2. Ehara, S. 1992. "Study of Thermal Processes beneath Kuju Volcano, Japan: A Step to Volcano Energy Utilization," in Transactions, vol. 16. Proceedings of the Annual Meeting of the Geothermal Resources Council: Restructuring the Geothermal Industry, San Diego, CA, 4-7 October, pp. 153-156. Report no. CONF-921083. Available from Geothermal Resources Council, 2001 Second Street, Suite 5, PO Box 1350, Davis, CA 95617.

3. Hori, Y.; K. Kitano; and H. Kaieda. 1994. "Outline of Ogachi Project for the HDR Geothermal Power In Japan," in Transactions, vol. 18. Proceedings of the 1994 Annual Meeting of the Geothermal Resources Council: Restructuring the Geothermal Industry, Salt Lake City, UT, 2-5 October, pp. 439-443. Report no. CONF-941043. Available from Geothermal Resources Council, 2001 Second Street, Suite 5, PO Box 1350, Davis, CA 95617.

4. New Energy and Industrial Technology Development Organization. 1993. "Development of 10MW-Class Power Plant," in Japan's Sunshine Project, pp. 73-77. Report no. ETDE/ JP-mf-94768086. Order no. DE94768086. Available from OSTI, NTIS.

5. New Energy and Industrial Technology Development Organization. 1993. "Nationwide Geothermal Resources Exploration Project," in Japan's Sunshine Project, pp. 73-77. Report no. ETDE/JP-mf-94768086. Order no. DE94768086. Available from OSTI, NTIS.

6. Tomita, M.; S. Saito; and T. Suzuki. 1994. "Recently Developed Geothermal Power Plants in Japan," in Transactions, vol. 18. Proceedings of the 1994 Annual Meeting of the 
Geothermal Resources Council: Restructuring the Geothermal Industry, Salt Lake City, UT, 2-5 October, pp. 563-568. Report no. CONF-941043. Available from Geothermal Resources Council, 2001 Second Street, Suite 5, PO Box 1350, Davis, CA 95617.

7. Horikoshi, T. "Current Status of R\&D on Geothermal Resource Prospecting Technology in Japan," in Proceedings of APEC Energy R\&D and Technology Transfer and Renewable Energy Resource Assessment Seminar, Beijing, China, February.

\section{Solar}

1. Yoshida, S. and S. Shinoki. 1980. "Monthly Mean Global Solar Radiation Maps for Japan," in Energy Developments in Japan vol. 2. Chicago: Rumford Publishing Company, Inc., pp. 211-251.

2. Yoshida, S. and S. Shinoki. 1982. "Maps of Monthly and Annual Directorate Solar Radiation and Its Year-to-Year Variation Estimated on the Basis of JMA Station Data," Journal of JSES 8(2).

3. Yoshida, S. and S. Shinoki. 1982. "Maps of Monthly and Annual Hours with Sunshine and Its Year-to-Year Variation Modified on the Basis of JMA Station Data," Journal of JSES 8(5).

4. Yoshida, S. and S. Shinoki. 1985. "Detailed Maps of Monthly and Annual Mean Global Solar Radiation Estimated on the Basis of AMeDAS Data," Journal of JSES 11(3).

5. Yoshida, S.; S. Shinoki.; and A. Itagaki. "Solar Radiation Research in the SunshineProject of Japan." Japan Weather Association, Kaiji Center Bldg., Koji-machi 4-5, Chiyodaku, Tokyo 102, Japan.

6. Yoshida, S.; S. Shinoki; and H. Kikuchihara. 1986. "Detailed Maps of Monthly and Annual Mean Diffuse Sky Radiation Estimated on the Basis of AMeDAS Data," Journal of JSES 12(2).

\section{Wind}

1. Abe, K. 1994. "Report on the First All Japan Wind Summit," Furyoku Enerugi (Wind Energy) (Japan) 18(2), pp. 1-4. ISSN: 0387-6217.

2. New Energy Development Organization. 1990. "Development of a Large Wind Power Generation System. Development of a MW-Class Large Wind Power Generation System (Observation of Wind Conditions)," in 1989 NEDO Annual Summary of Studies, pp. 290301. Report no. ETDE/JP-mf-1513221, Order no. DE91513221. Available from OSTI, NTIS.

3. Otsuka, K.; H. Okada; and Y. Miyagawa. 1994. "Study on the Assessment of Wind Power by Three-Dimensional Meso-Scale Meteorological Model. Estimation of Wind Potential of Tsugaru Peninsula in Aomori Prefecture," Obayashi-Gumi Gijutsu Kenkyusho-Ho (Report of the Engineering Research Laboratory Obayashi-Gumi) (Japan) vol. 48, pp. 121-126. ISSN: 0385-9657.

4. Shimizu, Y.; S. Kurokawa; S. Ota; and S. Furuichi. 1988. "Investigation of Wind Energy in the Central Mountainous District of Mie Prefecture (Aoyama Highlands)," Furyoku Enerugi (Japan) 12(1), pp. 14-17. 
5. Shimizu, Y. 1993. "Possibility of Wind Power Generation in Japan," Furyoku Enerugi (Japan) vol. 33, pp. 1-16. ISSN: 0387-6217.

6. Shinohara, M.; M. Ueda; and S. Tada. 1992. "Potential Wind Energy Resources in the Kinki District: Results of Survey," in 1992 Japan Solar Energy Society/Japan Wind Energy Association Joint Conference, pp. 267-270. Report no. CONF-021276. Order no. DE93793955. Available from OSTI, NTIS.

7. Tono, M. and R. Miura. 1993. "Development of Wind Characteristics Map to Evaluate the Wind Energy," Furyoku Enerugi (Japan) 17(1), pp. 17-25. ISSN: 0387-6217.

8. Yaga, M.; M. Fang; and M. Nagai. 1992. "Characteristics of Wind and Wind Energy Resources at Nishihenna Cape of Miyako Island," in Ryukyu Daigaku Kogakubu Kiyo(Japan) vol. 43, pp. 1-8. ISSN: 0389-102X.

9. Yamada, S.; K. Tsuchiya; and N. Inomata. 1992. "Annual Energy Generation at Tappi Wind Park," in Tohoku Denryoku Kabushiki Kaisha Kenkyu Kiho (Japan) vol. 69, pp. 38-45. ISSN: 0285-5496.

10. Matsumiya, H. 1996 "Wind Resource Measurement and Promoting Activities for Wind Energy Development in Japan," in Proceedings of APEC Energy R\&D and Technology Transfer and Renewable Energy Resource Assessment Seminar, Beijing, China, February. 


\section{Republic of Korea (ROK)}

\section{General}

1. 1994. "The Urgency of Oil Conservation: Focus on South Korea," Energy Detente 14(11), pp. 3-7.

2. Johnson, C.; B. Li; and A. Lamke. 1995. "South Korea's Power Surge," World Coal, May, pp. 31-32, 34-37.

3. Sonn. Y.-H. 1993. "Korea: Electricity Deregulation and the Search for Gas," in Proceedings of the Conference on Asian Electricity: The Growing Commercialization of Power Generation, Singapore, 25-26 May, pp. 6.1-6.4. Report no. CONF-9305273. Available from British Library Document Supply Centre, Boston Spa, Wetherby, West Yorks LS23 7BQ.

4. 1997. "Exploring Korea: The Geographical Characteristics," Available through: http://www.kois.go.kr/exploring/landplp/geo.html\#3.

5. 1997. "R\&D Activities on Energy and Resources Technology; Renewable Energy," RaCER Renewable Energy Available through: http://www.racer.or.kr:80/act/act2.html.

6. Jung, Y. 1996. "Scenarios of Future Energy Demand and Carbon Dioxide Emissions in the Republic of Korea," Ambio, Vol. 25, No.4, p. 258

\section{Geothermal}

1. Ahn, J.S. andY.K. Koh. 1993. "Environmental Isotope-Aided Studies on Geothermal Water in the Republic of Korea," in Proceedings of the Final Research Co-ordination Meeting on the Application of Isotope and Geochemical Techniques to Geothermal Exploration in the Middle East, Asia, the Pacific and Africa, Dumaguete City, the Philippines, 12-15 October, pp. 113-125. ISSN: 1011-4289. Available from OSTI, NTIS, INIS.

\section{Solar}

1. Song, J. 1993. "The National Photovoltaic Project in Korea," Energy Sources 15(1), pp. 51-58. ISSN: 0090-8312.

2. Personal Contact: D.H. Eunilkim. Solar Radiation Tables.

3. Song, J. 1996. "Recent Trends in PV Technology R\&D in Korea," in Proceedings of APEC Energy R\&D and Technology Transfer and Renewable Energy Resource Assessment Seminar, Beijing, China, February.

\section{Wind}

1. Kim, K.-H. 1993. "Experience Gained with Wind Energy Utilization in South Korea," Turbomachinery Utilization, pp. 89-101. ISSN: 0178-9414; ISBN: 3-18-148606-X. Duesseldorf, Germany: VDI-Verl. 


\section{Malaysia (MAS)}

\section{General}

1. Dalimin, M.N. 1995. "Renewable Energy Update: Malaysia," Renewable Energy 6(4), pp. $435-439$.

\section{Hydro}

1. Dansie, J. 1994. "Striking the Balance in Malaysia," International Water Power and Construction 46(12), pp. 30-31. ISSN: 0306-400X.

\section{Solar}

1. Chuah, D.G.S. and S.L. Lee. 1981. "Solar Radiation Estimates in Malaysia," Solar Energy 26, pp. 33-40.

2. Chuah, D.G.S. and S.L. Lee. 1982. "Solar Radiation in Peninsular Malaysia-Statistical Presentations,” Energy Convers. Mgmt. vol. 22, pp. 71-84.

3. Othman, M.Y.H.; K. Sopian; B.Yatim; and M.N. Dalimin. 1.993. "Diurnal Pattern of Global Solar Radiation in the Tropics: A Case Study in Malaysia," Renewable Energy 3(6/7), pp. 741-745.

4. Sopian, K. and M.Y.H. Othman. 1992. "Estimates of Monthly Average Daily Global Solar Radiation in Malaysia," Renewable Energy 2(3), pp. 319-325.

5. Zain-Ahmed, A. 1992. "A Model to Estimate Radiation on Horizontal and Inclined Surfaces for Malaysia," in Renewable Energy: Technology and the Environment. Proceedings of the 2nd World Renewable Energy Congress, Reading, UK, 13-18 September, pp. 2494-2498.

6. Zain-Ahmed, A. 1993. "Solar Radiation Estimation in Malaysia," International Energy Conference, Seoul, Energex'93 Proceedings, vol.3 October.

\section{Wind}

1. Exell, R.H.B. and C.T. Fook. 1986. "Wind Energy Potential of Malaysia," Sol. Energy 36(3), pp. 281-289.

2. Sopian, K.; M.Y.H. Othman; and A. Wirsat. 1995. "The Wind Energy Potential of Malaysia," Renewable Energy 6(8), pp. 1005-1016. 


\section{Mexico (MEX)}

\section{General}

1. Corbus, D.; M. Martinez; L. Rodriguez; and J. Mark. 1994. Renewable Energy and Its Potential for Carbon Emissions Reductions in Developing Countries: Methodology for Technology Evaluation. Case Study Application to Mexico. Golden, CO: National Renewable Energy Laboratory. NREL/TP-463-6504, DE94011870.

2. Martinez, M. 1990. "Renewable Energy for Rural Development in Mexico," in Energy for Rural Development. Proceedings of the Meeting of the United Nations Group of Experts on the Role of New and Renewable Sources of Energy in Integrated Rural Development, Stockholm, Sweden, 22-26 January, pp. 219-224. ISBN: 1-85649-037-8.

3. Matsumoto, Y.; A. Urbano; A.M. Martinez; and R. Asomoza. 1994. "Renewable Energy Application Progress in Mexico," Renewable Energy 5(1), pp. 330-332.

\section{Geothermal}

1. Hiriart-LeBert, G. and L.C.A. Gutierrez-Negrin. 1994. "Geothermal Development in Mexico," Transactions vol. 18. Proceedings of the 1994 Annual Meeting of the Geothermal Resources Council: Restructuring the Geothermal Industry, Salt Lake City, UT, 2-5 October, pp. 269-274. Report no. CONF-941043. Available from Geothermal Resources Council, 2001 Second Street, Suite 5, PO Box 1350, Davis, CA 95617.

2. Quijano, L. and R. Sanchez. 1994. "Expansion Possibilities of the Los Azufres Geothermal Field," Transactions vol. 18. Proceedings of the 1994 Annual Meeting of the Geothermal Resources Council: Restructuring the Geothermal Industry, Salt Lake City, UT, 2-5 October, pp. 281-282. Report no. CONF-941043. Available from Geothermal Resources Council, 2001 Second Street, Suite 5, PO Box 1350, Davis, CA 95617.

3. Venegas, S. and J. Alvarez. 1994. "Exploration in the Laguna Salada GeothermalZone B.C., Mexico," in Transactions vol. 18. Proceedings of the 1994 Annual Meeting of the Geothermal Resources Council: Restructuring the Geothermal Industry, Salt Lake City, UT, 2-5 October, pp. 291-295. Report no. CONF-941043. Available from Geothermal Resources Council, 2001 Second Street, Suite 5, PO Box 1350, Davis, CA 95617.

\section{Solar}

1. Herandez, E.; Tejeda, A.; Reyes, S. "Atlas Solar de le Republica Textos Universitarios, Mexicana".

2. Almanza Salgado, R.; R.V. Estrada-Cajigal; A. J. Barrientos. 1992. "Actualizacion de los Mapas de Irradiacion Global Solar en la Republica Mexicana," Series del Instituto de Ingenieria, No. 543, UNAM, Septiembre.

3. Galindo, I.; A. Chavez. 1977. "Estudio del Clima Solar en la Republica Mexicana. I. Radiacion Solar Total," Instituto de Geofisica, UNAM y Direccion General del Servicio Meteorologico Nacional.

4. Estrada-Cajigal R.V. 1994. Direct Normal Irradiation in Mexico Using the DIM Model. Internal Report. 
5. Jauregui, E. 1990. "Aspects of Global and Diffuse Solar Radiation in Mexico City," in II Taller de Radiacion Solar, Instituto de Investigaciones Electricas, 23-25 May, Palmira, Morelos, Mexico.

6. Estrada-Cagigal R.V. "Irradiacion Global Horaria Obtenida de Datos De Satelite," SolarTronic, S.A. DE C.V.

7. Estrada-Cagigal R. V. 1995. “Solar Radiation Data for Mexico," Prepared for NREL under subcontract No. TAH-5-15150-01, August.

8. Estrada, I.G. “MEXICO Atlas de Radiacion Solar," Documentos de Analisis y Prospectiva del Programa Universitario de Energia

9. Estrada-Cagigal R.V. "Metodos de Calculo de la Radiacion Solar," SolarTronic, S.A. De C.V. Av. Morelos Sur No. 1301-E Cuernavaca, Morelos.

10. Estrada-Cagigal R.V. 1993. "Estimates of Available Solar Radiation and Photovoltaic Energy Production for Tilted Surfaces throughout Mexico Based on Satellite Derived Data," SolarTronic, December.

\section{Wind}

1. Schwartz, M.N. and D.L. Elliott. 1995. Mexico Wind Resource Assessment Project. Golden, CO: National Renewable Energy Laboratory, TP-441-7809, DE95009202. 


\section{New Zealand (NZ)}

\section{Biomass}

1. Sims, R.E.H. 1993. "The Opportunities for Woody Biomass Fuels in New Zealand Produced in Association with Land Disposal of Effluent," in Proceedings of the First Biomass Conference of the Americas, vol. 3, Burlington, VT, August 30-September 2, pp. 1640-1644.

2. Sims, R.E.H. 1994. "Electricity Generation from Woody Biomass Fuels Compared with Other Renewable Energy Options," Renewable Energy 5(2), pp. 852-856.

3. Sims, R.E.H.; T. Maiava; and C. Williams. 1993. "Bio Fuels Production-The New Zealand Research Programme," in Proceedings of ENERGEX '93, vol. 3, Seoul, Korea, 18-22 October, pp. 1-12.

\section{General}

1. Yamaguchi, N.D and H.D. Keevill. 1992. New Zealand: Asia-Pacific Energy Series, Country Report. Report no. DOE/IE/10859-T3, Order no. DE92011901. Available from OSTI, NTIS, INIS, GPO Dep.

2. Sims, R.E.H. 1996. “A Sustainable Energy Future for New Zealand," Renewable Energy, Vol. 9, il-4, pp. 1049-1054, September.

\section{Geothermal}

1. Allis, R.G. and H. Hase. 1994. "Volcano-Hydrothermal Energy Research at White Island, New Zealand, in Proceedings of the IEA International Conference on Technology Responses to Global Environmental Challenges: Energy Collaboration for the 21st Century, Kyoto, Japan, 6-8 November, pp. 409-416.

\section{Hydro}

1. Macdonald-Smith, A. 1995. "New Zealand Powers Up," International Water Power and Dam Construction 47(2), pp. 19-20.

\section{Solar}

1. Western, B.E. 1990. “The Estimation of Solar Radiation in New Zealand," Solar Energy Wind 45(3), pp. 121-129.

1. Dawber, K.R.; G.D. Neilson; and D.R.A. Fraser. 1994. "Wind Gust Statistics and Turbulence Studies during Storms at a Wind Generator Site in Central Otago, New Zealand," Renewable Energy 5(1), pp. 730-732.

2. Edwards, P.J. 1990. "Wind Energy Resource Studies in New Zealand," Solar and Wind Technology 7(1), pp. 9-14. ISSN: 0741-983X.

3. Reid, S.J. 1990. "Wind Energy Research in New Zealand," Energy and the Environment: Into the 1990s, vol. 3, CONF 900901, ISBN: 0-08-037539-1. 
4. Reid, S.J. 1992. "New Zealand: Wind Energy Potential," Renewable Energy Technology and the Environment, vol. 3, CONF 920923, ISBN: 0-08-0412785. 


\section{Papua New Guinea (PNG)}

\section{General}

1. Gafiye, G.D. 1990. "Energy Developments at the Appropriate Technology Development Institute, Papua New Guinea," Solar \& Wind Technology 7(1), pp. 73-78.

2. Jones, G.J. 1992. Trip Report to South Pacific: Pacific Island Opportunity Identification Project. Golden, GO: National Renewable Energy Laboratory.

\section{Hydro}

1. Hauck, E. 1991. "Anditale Micro Hydro in the Enga Province Papua New Guinea," in Hydroelectric Power and Hydroelectric Power Plants, vol. 1. Proceedings of the International Conference and Exhibition on Hydroelectric Power and Hydroelectric Power Plants, Nice, France, 12-15 June, pp. 683-699. ISBN: 2-86817-042-0.

2. Kiewiet, W.C. 1991. "Micro Hydro Electrical Installations: An Action Plan for Papua New Guinea," in Hydroelectric Power and Hydroelectric Power Plants, vol. 1. Proceedings of the International Conference and Exhibition on Hydroelectric Power and Hydroelectric Power Plants; Nice, France, 12-15 June, pp. 700-709. ISBN: 2-86817-042-0.

3. Portfors, E.A.; N.A. Morrison; and J. Lampa. 1990. "OK Menga Hydroelectric Project: Papua New Guina," in Transactions of the Engineering and Operating Division of the Canadian Electrical Association, pp. 1-20. Report no. CEA-CE04263, vol. 29. Available from Canadian Electrical Association, One Westmount Square, Suite 1600, Montreal, QB, CAN H3Z 2P9.

\section{Solar}

1. Ahmad, Q.A. 1983. "Solar Radiation at Lae, Papua New Guinea," in Solar World Congress. Proceedings of the Eighth Biennial Congress of the International Solar Energy Society, Perth, 14-19August, pp. 2163-2167.

2. Renné, D.S.; T.A. Ackerman; and W.E. Clements. 1994. "Probe: The Pilot Radiation Observation Experiment," in Eighth Conference on Atmospheric Radiation, Nashville, TN: 23-28 January. Published by the American Meteorological Society, Boston, MA.

3. Yeboah-Amankwah, D. and K. Agyeman. 1990. "Differential Ängstrom Model for Predicting Insolation from Hours of Sunshine," Solar Energy 45(6), pp. 371-377. 


\section{Republic of the Philippines (RP)}

\section{Biomass}

1. Cruz, I.E. 1992. "Agricultural and Forestry Waste Utilization for Energy," Philippine Technology Journal 17(3), pp. 3-27.

2. Perlack, R.D.; L.L. Wright; M.A. Huston; and W.E. Schramm. 1995. Biomass Fuel from Woody Crops for Electric Power Generation. Oak Ridge, TN: Oak Ridge National Laboratory. Report no. ORNL-6871. Available from OSTI, NTIS, GPO Dep.

\section{General}

1. Cannon, E. and A.L. Miranda. 1990. Industry Sector Analysis: The Market for Renewable Energy Resources. Washington, D.C.: International Trade Commission. Report no. PB-93- 145019/XAB. Available from NTIS.

\section{Geothermal}

1. 1994. “Geothermal in the Philippines," Independent Energy pp. 98-99, July/August.

2. Barbier, E. 1990. "Geothermal Energy: Its Role in the Energy Scenario," in Energy and the Environment into the 1990s. Proceedings of the 1st World Renewable Energy Congress, Reading, UK, 23-28 September. Pergamon Press.

3. Mesquite Group. 1992. Leyte 'A' Geothermal Project Optimization: Review of Improved Resource Performance and Power Generation Strategies for the Greater Tongonan Field. Export Trade Information. Report no. PB-95-178554/XAB. Available from NTIS.

4. Mesquite Group. 1995. Mahagnao Geothermal System Resource Assessment Review Report. Export Trade Information (Final). Report no. PB-95-178547/XAB. Available from NTIS.

5. Ogena, M.S. 1992. "Development Case Histories: Tongonan and Palinpinon Geothermal Fields, Philippines," Energy Spectrum (Philippines), 1992 issue, pp. 39-51.

6. Sarmiento, Z.F.; B.G. Aquino; Z.P. Aunzo; N.O. Rodis; and V.S. Saw. 1993. “An Assessment of the Tongonan Geothermal Reservoir, Philippines, at High-Pressure Operating Conditions," Geothermics 22(5-6), pp. 451-466.

7. Sussman, D.; S.P. Javellana; P.J. Benavidez; and Biliman 1993. "Geothermal Development in the Philippines: an Overview," in Geothermics 22(5-6), pp. 353-367.

\section{Hydro}

1. McCandless, D.H. 1993. “Aggressive Development Plans," Independent Energy 77-79, November.

\section{Solar}

1. Zamora, C.G. 1994 "Research and Development Promotion and Commercialization of Solar Photovoltaic (PV) Technology in the Philippines," Workshop-1994 April: Hyderabad; India, pp. 49-60, ISBN 8120409973. 


\section{Singapore (SIN)}

\section{Biomass}

1. Taiganides, E.P. 1992. Pig Waste Management and Recycling: The Singapore Experience. Ottawa, ON: International Development Research Centre. Report no. MIC-93-01985/XAB, ISBN: 0-88936-591-1.

\section{General}

1. Arismunandar, A. and P. Dupuis. 1992. "Energy in ASEAN: An Outlook into the 21st Century," Space Power 11(3-4), pp. 251-264.

\section{Hydro}

1. Afshar, Y. and R.W. Kwiatkowski. 1990. "Development of a Major Hydroelectric Project in the Pacific Rim," in Power-Gen '90: 3rd International Power Generation Industries Conferences and Exhibition. Orlando, FL, 4-6 December, pp. 201-208.

\section{Solar}

1. Goh, T.N. 1979. "Statistical Study of Solar Radiation Information in an Equatorial Region (Singapore)," Solar Energy vol. 22, pp. 105-111.

2. Hawlader, M.N.A. 1984. "Diffuse, Global and Extraterrestrial Solar Radiation for Singapore," International Journal of Ambient Energy 5(1), pp. 31-38.

3. Hawlader, M.N.A.; T.Y. Bong; and W. Mahmood. 1990. "Some Frequently Used Meteorological Data for Singapore," Int. J. Solar Energy vol. 8, pp. 1-11.

4. Rao, K.R. and B.P. Lim. 1978. "Solar Energy Availability at Singapore," in Sun: Mankind's Future Source of Energy. Proceedings of the International Solar Energy Society Congress, New Delhi, India, January. Pergamon Press.

5. Tan, K.J. and T.N. Goh. 1977. "Solar Insolation in an Equatorial Region (Singapore)," Solar Energy vol. 19, pp. 101-103. 


\section{Chinese Taipei (CT)}

\section{Biomass}

1. Chou, C.-H. 1989. "Allelopathic Interaction in a Pasture-Forest Intercropping System," in Proceedings of the International Chemical Congress of Pacific Basin Societies, Honolulu, HI, 17-22 December, p. 65. Report no. CONF-891206.

\section{General}

1. Tzeng, G.-H.; T.-A. Shiau; and C.-Y. Lin. 1992. “Application of Multicriteria Decision Making to the Evaluation of New Energy System Development in Taiwan," Energy 17(10), pp. 983-992.

2. Liu, C.-M. 1991. "Climate and Air-Quality Taiwan Station," in Proceedings of the Asian Workshop, New Delhi, India, 11-15 February, 1991, pp. 130-134. Report no. CONF-9102198. Available from British Library, Document Supply Centre, Boston Spa, Wetherby, West Yorks LS23 7BQ, UK.

3. Chin, T. 1994. "Energy Technology Transfer and Energy Situation in Each Country. Utilization Situation of Solar Energy and Wind Energy in Taiwan," Taiyo Enerugi (Journal of Japan Solar Energy Society) 20(3), pp. 34-36. ISSN: 0388-9564.

\section{Geothermal}

1. Jin, X. 1988. "Relation between the Geotemperature Distribution and the Geotectonics in China," in Exploration and Development of Geothermal Resources. Proceedings of the International Symposium on Geothermal Energy, Kumamoto, Japan, 10-14 November, pp. 570-571. Report no. GRSJ-8901, CONF-881170. Available from NTIS, PC A99/MF A01.

\section{Hydro}

1. Chang, S.C.; H.H. Chen; and I.K. Fong. 1990. "Hydroelectric Generation scheduling with an Effective Differential Dynamic Programming Algorithm," IEEE Transactions on Power Systems 5(3), pp. 737-743.

2. Marier, D. 1988. "Hydro Project Updates," Alternative Sources of Energy, November, pp. 21-26.

\section{Solar}

1. Lin, C. 1992. "The Accomplishment of a Solar Heat Promotion Program in Taiwan," in International Symposium on Energy, Environment and Information Management, pp. 3.43-3.47. Argonne, IL, 15-18 September. Report no. ANL/PROC-77473, Order no. TI93110757. Available from OSTI, NTIS, INIS.

\section{Wind}

1. McNerney, G.; D. Blodgett; J. Croyle; A. Chertok; 1991 "A Wind Diesel System installed on the Taiwan Island of Chi-Mei," 10th ASME Wind Energy Symposium, SED-vol. 11. 


\section{Thailand (THA)}

\section{Biomass}

1. Howe, R. 1991. "Costs and Performance of Equipment for Baling Sugarcane Tops and Leaves," in Proceedings of the European Conference on Biomass for Energy, Industry and Environment, Athens, Greece, 21-27 April, pp. 357-361. London: Elsevier Applied Science. ISBN: 1-85166-730-X.

\section{General}

1. 1993. "Energy and the Economy: Soaring Development in Thailand," Energy Detente 14(15), pp. 1-17.

2. Van Dang, G.; L.B. Minh; and S. Yodmani. 1994. "Key Challenges Facing Thailand in the Context of Global $\mathrm{CO}_{2}$ Emission Abatement," Energy Policy 22(11), pp. 971-980.

3. Foreign and Commonwealth Office, London. 1991. Thailand: The Power Sector. SectorReport. Available from DTI Export Publications, PO Box 55, Stratford-upon-Avon, Warwickshire CV37 9GE, UK.

4. Hennagir, T. 1995. “Indochinese Power Progress," Independent Energy 25(6), pp. 60-65.

5. Sabhasri, S. and P. Wibulswas. 1992. "Thai Energy Sources and Related Environmental Issues," Utilities Policy 20(6), pp. 522-526.

6. Sagetong, P. 1991. "Thailand," in Global Warming: Collaborative Study on Strategies to Limit $\mathrm{CO}_{2}$ Emissions in Asia and Brazil. Proceedings of Workshop for the Collaborative Study on Asia's and Brazil's Contribution to GHG Emissions and Policy Responses for their Minimization, New Delhi, India, 21-22 September, pp. 171-190. Report no. CONF-9109490. Available from Tata McGraw-Hill Publishing Co., Ltd., 4/12 Asaf Ali Road, New Delhi 110 002, India.

7. Salisdisouk, N. "Thailand's Power System: A Rigorous Growth Strategy," Power Generation Technology, pp. 27-28, 30--32, 34. ISSN: 0957-1361.

8. Sheerin, J. 1992 "Energy and Economic Interaction in Thailand," Energy Journal, Vol.13, N1, pp. 145-157.

\section{Hydro}

1. Chullakesa, C. 1991. "Technology Applicable to Thailand's Small Hydro Development," in Proceedings of the International Conference and Exhibition on Hydroelectric Power and Hydroelectric Power Plants, Nice, France, 12-15 June, pp. 178-188. Report no. CONF-9106129. ISBN: 2-86817-042-0.

2. Dansie, J. 1994. "Laos Hydro to Power Thai Economy," International Water Power and Dam Construction 46(3), pp. 18-20.

3. Dansie, J. 1995. "Mixed Reactions to Mekong Mega-Project," International Water PowerLand Dam Construction 47(6), pp. 46-47. 


\section{Solar}

1. Akuffo, F.O. and A. Brew-Hammond. 1993. "The Frequency Distribution of Daily Global Irradiation at Kumasi," Solar Energy 50(2), pp. 145-154.

2. Exell, R.H.B. 1976. "The Fluctuation of Solar Radiation in Thailand," Solar Energy vol. 18, pp. 549-554.

3. Jivacate, C.; S. Mongconvorawan; E. Sinratanapukdee; and W. Limsawatt. 1994. "Performance Evaluation of a 2-Mode PV Grid Connected System in Thailand-Case Study," in 1994 IEEE First World Conference on Photovoltaic Energy Conversion. Conference Record of the Twenty Fourth IEEE Photovoltaic Specialists Conference, vol. 2, Waikoloa, HI, 5-9 December, pp. 2333-2340.

4. Kirtikara, K.; T. Suwannakam; S. Suvarawan; R. Songprakob; and S. Thepa. 1994. "Thailand Natioanl Photovoltaic Water Pumping Programme," in Solar '94: Secrets of the Sun, vol. 2. Proceedings of the Electrical Engineering Congress: Enabling Technologies Developing Industry, Sydney, Australia, 24-30 November, pp. 584-590.

5. Suwannaku, T.; K. Kirtikara; S. Thepa; R. Suwaravan; R. Songprakob; and D. Pongchawee. 1994. "Field Experience with Photovoltaic Pumping Systems," in Solar '94: Secrets of the Sun, vol. 2. Proceedings of the Electrical Engineering Congress: Enabling Technologies Developing Industry, Sydney, Australia, 24-30 November, pp. 591-597.

6. Hirunlabn, J.; Santisirisomboon, J.; Namprakai, P.; 1994. “Assessment of Solar Radiation for Thailand," Presented at an International Workshop: Calculation for Solar Energy Systems on September 29-30, Universite` de Perpignan, France. pp. 1-14.

7. Janjai, S. 1991. "A Model for Computing Daily Diffuse Solar Radiation," in Trends and Issues in the Development and Use of New and Renewable Sources of Energy in the Asia-Pacific Region, Proceedings of Asia Energy'91: the First Asian International Conference on New and Renewable Energy Information on Policy, Planning, Technology and Equipment, 17-20 October, Bangkok, Thailand. V. 2 Economic and Social Commission for Asia and the Pacific, United Nations, New York 1994.

8. Exell, R.H.B. 1976. "The Solar Radiation Climate in Thailand," The Journal of Solar Energy Science and Technology, Vol. 18. No. 4, ISSN 0038-092X.

\section{Wind}

1. Jamkrajang, M. 1984. Feasibility of Utilizing Wind Energy in Thailand, Ph.D. Thesis. Columbia, MO: University of Missouri. Available from University Microfilms Order no. 8500,586 .

2. McNerney, G.; D. Blodgett; J. Croyle; and A. Chertok. 1991. "A Wind Diesel System Installed on the Taiwan Island of Chi-Mei," in SED Vol. 11, 10th ASME Wind Energy Symposium. 


\section{The United States of America (US)}

\section{Biomass}

1. Thomas, J.D, et al. 1986. "Forest Biomass Assessment for the Tennessee Valley Region," Tech. Note B57, TVA/ONRED/L\&ER-86/26, Tennessee Valley Authority, Norris, TN.

2. Deshaye, J.A.; J.D. Kerstetter. 1991. "Washington State Biomass Data Book," WAOENG 9110, Washington State Energy Office, Olympia, WA.

3. OTA. 1989. "Facing America's Trash-What Next for Municipal Solid Waste?" OTA-O-424, U.S. Congress, Office of Technology Assessment, U.S. Government Printing Office, Washington, D.C.

4. Meridian Corporation. 1986. "Waste-To-Energy-A Primer for Utility Decision Makers," Western Area Power Administration, Golden, CO.

5. Goodman, B.J. 1990. "Assessment of Municipal Solid Waste for Energy Production in the Western United States," SERI/TR-231-3622, Solar Energy Research Institute (now NREL), Golden, CO.

6. EPA. 1992. "Characterization of Municipal Solid Waste in the United States: 1992 Update," U.S. Environmental Protection Agency, Washington, DC.

7. Kahn, Z.K.; Sable, E. 1988. "Planning a Program to Determine Physical and Chemical Characteristics of Municipal Solid Waste," Resource Recovery/Cogeneration World, No. 1, pp. 15-18.

\section{General}

1. Maxwell, E.L.; and D.S. Renne'. 1994. "Measures of Renewable Energy Resources," NREL/MP-463-6254, National Renewable Energy Laboratory, Golden, CO, January.

2. Mustoe, J.E.H. 1984. An Atlas of Renewable Energy Resources in the United Kingdom and North America, John Wiley and Sons, New York, 202 pp.

\section{Geothermal}

1. Benoit, W.R.; Hiner, J.E.; Forest, R.T. 1982. "Discovery and Geology of the Desert Peak Geothermal Field: A Case History," Bulletin 97, Nevada Bureau of Mines and Geology, University of Nevada at Reno, Reno, NV.

2. Muffler, 1979. "Assessment of Geothermal Resources of the United States-1978," Geological Survey Circular 790, United States Geological Survey, Arlington, VA.

\section{Hydro}

1. Moreira, J.R.; Poole, A.D. 1993. "Hydropower and Its Constraints," Renewable Energy: Sources for Fuels and Electricity, ed. by Johansson, T.B. et al., Island Press, Washington, DC, pp. 1160.

2. Deudney, D. 1981. "Rivers of Energy: The Hydropower Potential," Worldwatch Paper 44, Worldwatch Institute, Washington, DC. 
3. Meridian Corporation. 1989. "Characterization of U.S. Energy Resources and Reserves," DOE/CE-0279, U.S. Department of Energy, Assistant Secretary Conservation and Renewable Energy, Office of Research and Technology Integration, Washington, DC.

4. UNESCO. 1977. Atlas of World Water Balance, Explanatory Text, The UNESCO Press, Paris, France.

5. FederalEnergy Regulatory Commission. 1988. "HydroelectricPowerResourcesin theUnited States: Developed and Undeveloped," FERC-0070, Washington, DC.

6. Sommers, G.L. 1991. "A Hydropower Program Reappears in the DOE Budget," Hydro Review, pp. 96-99, July.

\section{Solar}

1. Maxwell, E.L.; W.F. Marion; D.R. Myers; M.D. Rymes; S.M. Wilcox. 1992, 1995. National Solar Radiation Data Base 1961-1990, NSRDB, Vol. 1\&2, Technical Report, National Renewable Energy Laboratory, Golden, CO, January.

2. Knapp, C.L.; Stoffel, T.L.; Whitaker, S.D. 1980. "Insolation Data Manual and Direct Normal Solar Radiation Data Manual," SERI/SP-755-789, UC Category 59, 62, 63, Solar Energy Information Data Bank, Solar Energy Research Institute (now NREL), Golden, $\mathrm{CO}$, October. (earlier version of US-S1).

3. National Renewable Energy Laboratory. "Solar Radiation 1961-1990 Maps." Available through Renewable Resource Data Center, http://rredc.nrel.gov.

4. Marion, W.F.; Urban, K. 1995. "User's Manual for TMY2s (Typical Meteorological Years)," Derived from US-S1, NREL/SP-463-7668 DE95004064, National Renewable Energy Laboratory, Golden, CO, June. Available on CD-ROM.

5. Marion, W.F.; Wilcox, S.M. 1995. "Solar Radiation Data Manual for Buildings," NREL/ TP-463-7904 DE95009254, National Renewable Energy Laboratory, Golden, CO, September.

6. Marion, W.F.; and S.M. Wilcox. 1994. "Solar Radiation Data Manual for Flat-Plate and Concentrating Collectors," NREL/TP-463-5607 DE93018229, National Renewable Energy Laboratory, Golden, CO, April.

7. $\quad$ Clemons, J.W. "Direct Normal Radiation Estimates for 248 Locations in U.S.," Results of 'Sun Count"' Computer Simulation for Estimating Direct Insolation, Parabolic through Performance, and Financial Estimates, Luz Engineering Corporation, Birmingham, AL.

8. Hanson, K.; Stoffel, T.L. 1989. "Solar Radiation Monitoring Networks," in R.L. Hulstrom, ed., Solar Resources, The MIT Press, Cambridge, MA, Chap. 4, pp. 143-171.

9. SOLMET Vol. 1. 1978. "User's Manual-Hourly Solar Radiation-Surface Meteorological Observations," TD-9724, National Climatic Data Center, Ashville, NC.

10. SERI, 1981. "Solar Radiation Energy Resource Atlas of the United States," SERI/SP-6421037, Solar Radiation Research Institute (now NREL), Golden, CO. 
11. Kreith, F.; R.E. West, eds. 1997. CRC Handbook of Energy Efficiency, CRC Press, 1113 pp.

\section{Wind}

1. Elliot, D.L.; C.G. Holladay; W.R. Barchet; H.P. Foote; W.F. Sandusky. 1987. "Wind Energy Resource Atlas of the United States," DOE/CH10094-4, DE86004442 UC Category 60, Solar Technical Information Program, Solar Energy Research Institute (now NREL), Golden, CO, March.

2. $\quad$ Elliot, D.L.; and W.R. Barchet. "Wind Energy Resource Atlas, Volumes 1-12," PNL-3195, WERA-1 through WERA-2, Pacific Northwest Laboratory, Richland, WA.

3. De Renzo, D.J., ed. 1979. "Wind Power: Recent Developments," Energy Technology Review, No. 46, Noyes Data Corporation, Park Ridge, NJ, 347 pp.

4. Elliott, D.L.; M.N. Schwartz. 1993. "Wind Energy Potential in the United States," PNL-SA-23109, Pacific Northwest Laboratory (NTIS no. DE94001667), Richland, WA, September, $10 \mathrm{pp}$. 


\section{Southeast Asia Region (SE)}

\section{General}

1. Tasdemiroglu, E. and A. Ileri. 1995. "An Energy Picture of the Asian Developing Countries and Research Imperatives for Energy Development," Renewable Energy 6(8), pp. 925-939.

2. Schaeffer, L. 1994. "Support for Alternative Energy in Asia," Resources, Conservation and Recycling vol. 12, pp. 57-62.

3. Arismunandar, A. and P. Dupuis. 1992. "Energy in ASEAN: An Outlook Into the $21^{\text {st }}$ Century," Space Power vol. 11, 3 and 4, pp. 251-264.

\section{Solar}

1. 1991. "International Solar Irradiation Database; Version 1.0," University of Lowell Program, July 31. 


\section{Appendix B: Summary Content of Bibliography Citations (Listed in same order as in text; specific categories listed in same order as in reference table for each economy)}

\section{Australia (AUS)}

\section{Wind}

AUS-W1

AUS-W2

AUS-W3

AUS-W4

Solar

AUS-S 1

AUS-S2

AUS-S3

AUS-S4

AUS-S5

Abstract only, discusses measurements of wind energy.

Abstract only, comparison of wind energy estimation models.

Abstract only, describes a regional study of mesoscale effects on wind energy.

Characteristics of wind: density, speed, direction, statistical modelling and analysis, graphs, and charts.

General article, discusses achievements in measuring solar radiation and periods of measurements.

Includes three independent incomplete research papers, measurements of solar radiation, methods of estimating components of solar radiation, statistical data, first paper by Hutchinson et al . includes solar maps.

Abstract only, describes a solar centre at the University of New South Wales.

Describes procedure for selecting typical mean year solar radiation and temperature records.

General article, describes solar radiation monitoring network, includes a map of monitoring stations.

\section{Biomass}

AUS-B 1

AUS-B2

Abstract only, describes energy demand, biomass alternatives.

Abstract only, discusses possibilities of waste-energy utilization.

\section{Geothermal}

AUS-G1 Abstract only, describes geothermal projects.

AUS-G2 Abstract only, discusses HDR technology.

\section{Hydro}

AUS-H1

AUS-H2

Abstract only, describes advantages of hydro schemes.

WWW document, describes a hydro project on Ord River.

\section{General}

AUS-N1

AUS-N2

AUS-N3

Abstract only, describes power generation, includes percentages.

Abstract only, cost comparisons of energy alternatives.

AUS-N4 $\quad$ Describes wave energy potential.

AUS-N5 Describes energy supply, percentages.

\section{Brunei Darussalam (BD)}

\section{Solar}

BD-S1 Estimation models for solar radiation. 
BD-S2 Description and technical specifications of a solar cooker.

BD-S3 Measuring stations, location and measurements.

\section{Hydro}

BD-H1 Abstract only, discusses factors involved in developing an international energy project.

\section{General}

BD-N1 General statistical survey.

BD-N2 WWW document, general statistical survey.

BD-N3 WWW document, general statistical survey, includes a map of Brunei.

BD-N4 WWW document, general statistical survey, data on oil production.

\section{Canada (CDA)}

\section{Wind}

CDA-W1 Describes wind energy potential in Atlantic Canada, provides tables of measurements and costs, a map of sample wind sites.

CDA-W2 Abstract only, describes a summary of a survey of the wind energy resources in Alberta.

\section{Solar}

CDA-S 1

CDA-S2

Solar radiation measurement methods and stations, provides coordinates.

Solar radiation measurement methods (in detail) and stations, provides stations location map.

CDA-S3 User's manual for CWEEDS Data CD-ROM.

CDA-S4

CDA-S5

Describes the effects of volcanic eruption on solar radiation measurements.

CDA-S6

Abstract only, describes measurements of solar radiation.

Describes solar radiation measurement database, provides measured data and stations location maps.

CDA-S7 Abstract only, describes a comparison of solar irradiance modeling methods.

CDA-S8 Solar maps only (monthly breakdown).

\section{Biomass}

CDA-B 1

CDA-B2

CDA-B3

Abstract only, describes a bibliography of ENFOR (Energy from Forest) biomass reports.

Abstract only, describes a study of biomass resource in Saskatchewan.

Abstract only, describes a potential for lignocellulosic materials.

\section{Geothermal}

CDA-G1

CDA-G2

\section{Hydro}

CDA-H1

$\mathrm{CDA}-\mathrm{H} 2$

CDA-H3

$\mathrm{CDA}-\mathrm{H} 4$
Abstract only, describes advances in geothermal development in Nova Scotia. Abstract only, describes geothermal resources in British Columbia.

Abstract only, describes Hydro Review Magazine's survey of industry leaders. Abstract only, describes British Columbia's Hydro's Resource Smart program. Abstract only, describes the Canadian hydro energy potential.

WWW document, provides information on geothermal water use. 
Abstract only, describes renewable energy development in British Columbia. assessments. Designed to determine the technical and economic potential for non-utility power generation.

CDA-N3

Abstract only, economic analysis of five renewable energy resources.

CDA-N4

Abstract only, describes a status of renewable energy in Saskatchewan.

CDA-N5

General article, provides data on renewable energy development, percentages.

CDA-N6

Describes in detail energy sources and fuels within Saskatchewan.

CDA-N7 General weather data: air temperature, wind speed, precipitation, etc.

\section{Chile (CHL)}

\section{Wind}

CHL-Wl

CHL-W2

Abstract only, discusses wind energy potential and the state of its development.

CHL-W3

CHL-W4 Abstract only, describes the impact of coastal-low phenomenon on wind cycles. Abstract only, discusses wind energy potential, provides wind speed average, costs.

Evaluates wind energy potential, economic assessment, wind speed tables, graph of average hourly speeds for Calama.

\section{Solar}

CHL-S 1

CHL-S2

CHL-S3

Abstract only, describes measurements and estimation of solar radiation.

Solar radiation data, methods of estimation, tables, maps of global radiation.

Measurements of solar radiation, provides location coordinates of measuring stations, a map of average monthly maximums.

CHL-S4

Modeling methods for estimating solar radiation values, graphs.

CHL-S5

Modeling methods for estimating monthly incident solar radiation for tilted surfaces, tables.

\section{Geothermal}

CHL-Gl WWW document, describes Andean volcanic belt.

General

CHL-Gl Abstract only, describes economic conditions of Chilean utilities.

\section{People's Republic of China (PRC)}

\section{Wind}

PRC-Wl

PRC-W2

PRC-W3

PRC-W4

PRC-W5

PRC-W7

PRC-W8
Abstract only, discusses wind energy opportunities for Xinjiang Uygur Zizhigu region, costs. height.

Wind resource assessment for China, map of wind potential, technology overview. Abstract only, overview of wind technology development.

Abstract only, describes a paper on the objectives and work programme of Regional Working Group on Wind Energy Development and Utilization.

Measuring stations, graphs, wind energy measured data, costs for Fujian Province. General article, a feasibility study of small-scale PV-wind systems in Inner Mongolia Province, measurements of solar and wind energy, technology assessment, costs, tables. 
PRC-W9 General article on wind energy development, wind speed, wind farms, costs.

PRC-W10 General article, discusses wind energy development in Asia/Pacific region, includes wind maps for Fiji, Indonesia, Philippines, Viet Nam, Thailand, Japan, China and India, wind energy measurements, wind farms, technology overview, tables.

\section{Solar}

PRC-S1

Modeling methods for estimating solar radiation for South China, graphs and tables.

PRC-S2

PRC-S3

Abstract only, discusses the effects of aerosols on China's climate.

Climatic characteristics of Yunnan Province, solar radiation measurements tables, modeling methods, histograms, and graphs of solar radiation.

PRC-S4

Abstract only, discusses economic conditions in Western China, PV project.

PRC-S5

General article, includes measured data on solar, wind, biomass, wind, hydro and ocean/tidal resources, economic conditions overview, tables.

PRC-S6 General article, describes energy production and consumption, development of PV, PV technology overview.

PRC-S7 Modelling methods for estimating solar radiation values in Yunnan Province.

PRC-S8 Modelling methods for estimating solar radiation values in Yunnan Province, stations, measurements.

PRC-S9 General article, discusses both solar and wind technologies and hybrid system, measurements of solar radiation and wind energy.

PRC-S10 Modeling methods for estimating solar radiation, measurements by station, solar maps, tables.

Biomass

PRC-B1 Abstract only, market overview for biomass energy.

\section{Geothermal}

PRC-G1 Abstract only, overview of geothermal resource, provides locations.

\section{General}

PRC-N1

PRC-N2

PRC-N3

PRC-N4

PRC-N5

PRC-N6

PRC-N7

Abstract only, overview of energy supply, percentages.

Abstract only, overview of renewable energy development.

Abstract only, describes Chinese energy policy.

Assessment of Tibet's energy resources.

General article, discusses renewable energy sources and their applications, policy options.

General article, discusses various energy sources, policy options, cost comparison. General article, describes litigation, renewable energy sources, provides a table for renewable energies potential.

\section{Hong Kong, China (HKC)}

\section{Solar}

HKC-S1

$\mathrm{HKC}-\mathrm{S} 2$

HKC-S3

HKC-S4

HKC-S5

HKC-S6
Study of luminous efficacy of daylight, includes general climatic overview, charts. Modeling methods for estimating solar radiation, graphs.

Measurements of solar radiation, tables, graphs and charts.

Feasibility study of using solar energy for air conditioning, includes general climatic overview, charts, tables.

Modeling methods for estimating solar radiation, graphs and charts.

General article, discusses the application of PVtechnology, graphs. 


\section{General}

HKC-N1 Abstract only, describes energy production and consumption, percentages.

HKC-N2 Abstract only, describes energy production and consumption, percentages.

\section{Indonesia (INA)}

\section{Wind}

INA-W1 General report, wind development, energy production and consumption, tables, recommendations, wind project review.

INA-W2 Abstract only, wind technology development, percentages.

\section{Solar}

INA-S1

Survey of various regions, solar radiation measurements and map, tables, modeling methods.

\section{Biomass}

INA-B1 Overview of forestry industry and resources, tables, charts, and graphs.

\section{Geothermal}

INA-G1

INA-G2

INA-G3

\section{General}

INA-N2

INA-N2

INA-N4
Abstract only, overview of development of geothermal energy, sites.

Abstract only, overview of development of geothermal energy, sites, plans.

Overview of geothermal resource, development, policy, maps, and charts.

\section{Japan (JPN)}

\section{Wind}

JPN-W1

JPN-W2

JPN-W3

JPN-W4

JPN-W5

JPN-W6

JPN-W7

JPN-W8

JPN-W9

JPN-W10
General article, discusses energy planning and development.

General article, discusses energy demand and development, renewables, percentages.

Abstract only, discusses Indonesia's energy needs.

Abstract only, describes a summit held August 5-6 in Tachikawa-machi, Yamagata Prefecture that dealt with installation of wind power facilities and energy policy. Abstract only, observations of wind characteristics at the Muroto headland and in the Miyako islands applied to simulation model.

Abstract only, describes methods of assessments of wind energy in the region of Tsugaru Peninsula, Aomori Prefecture,

Abstract only, measurements of wind speed and electrical output in Mie Prefecture.

Abstract only, summarizes a paper on current status of wind power generation in Japan, measurements, feasibility study of potential power generation from wind power plants.

Abstract only, describes a study of wind energy potential at Kinki district. Abstract only, describes a creation of wind map, identifies potential sites.

Abstract only, observations of wind characteristics at Nishihenna cape in Miyako Island, measurements.

Abstract only, describes an experimental study of wind energy at Tappi wind park.

General article, describes wind power utilization, installed WTGs in Japan, costs, includes wind atlas of Japan, measurements, tables, test project. 


\section{Solar}

JPN-S1 Solar radiation maps for Japan, modeling methods, graphs, tables, measurements JPN-S2 through JPN-S4 and JPN-S6:

Solar radiation maps (in Japanese).

JPN-S5 Describes in detail the results of solar radiation research, modeling methods, maps, graphs and charts.

\section{Geothermal}

JPN-G1

JPN-G2

JPN-G3

JPN-G4

JPN-G5

JPN-G6

JPN-G7

\section{General}

JPN-N1

JPN-N2

JPN-N2

JPN-N3

JPN-N4
Abstract only, describes a report on geothermal energy studies during FY 1991. Abstract only, describes volcanic energy at central Kyushu. Abstract only, describes HDR geothermal energy production. Abstract only, describes an environmental influence survey of geothermal energy. Abstract only, describes a nationwide geothermal resources exploration project. Abstract only, describes Japan's new geothermal plants. General article, describes current status of R\&D on geothermal resource in Japan, describes surveys, maps.

\section{Republic of Korea (ROK)}

\section{Wind}

ROK-W1 Abstract only, describes wind energy development.

\section{Solar}

ROK-S1

ROK-S2

Abstract only, describes NEDO's role in development of renewable energy, discusses an overview of issues that face Japanese initiatives in the development of new technologies.

ROK-S3 Development of PV technology in Korea, goals and achievements, installed capacity tables, projects.

\section{Geothermal}

ROK-G1 Abstract only, describes geothermal water in Yusung.

ROK-N1 Abstract only, describes energy supply and demand.

ROK-N2 Abstract only, describes energy supply and demand, percentages.

ROK-N3 Abstract only, describes energy supply and demand, use of natural gas, percentages.

ROK-N4 WWW document, geographical characteristics of Korea.

ROK-N5 WWW document, R\&D on energy and technology by stages.

ROK-N6 Describes energy demand scenarios, percentages, emissions, tables, charts. 


\section{Malaysia (MAS)}

Wind

MAS-Wl

MAS-W2

Solar

MAS-Sl

MAS-S2

MAS-S3

MAS-S4

MAS-S5

MAS-S6

Hydro

MAS-Hl

General

MAS-Nl
Abstract only, measurements of wind energy.

Estimates of wind potential, modeling methods, maps, graphs, tables of measurements for principal locations.

Estimates of solar radiation for principal locations, modeling methods, tables, stations locations map, graphs.

Statistical analysis of solar radiation in peninsular Malaysia, modeling methods, map of stations locations, tables of measurements, charts.

Characteristics of solar radiation in Bangi, graphs, charts.

Estimates of solar radiation, modeling methods, tables, graphs.

Estimates of solar radiation, modeling methods, graphs, charts.

Estimations of solar radiation, graphs and charts.

Discusses Malaysian potential for hydroelectric development, proposed projects review.

Sources of energy are discussed, supply and demand, percentages, renewable energy applications, electrical needs.

\section{Mexico (MEX)}

\section{Wind}

MEX-Wl Assessment of wind resource in Mexico, includes maps, graphs, and tables.

\section{Solar}

MEX-S1

MEX-S2

MEX-S3

MEX-S4

MEX-S5

MEX-S6

MEX-S7

Modeling methods for estimation of solar radiation, maps, tables.

Measurements and estimates of solar radiation, map of stations locations, graphs.

Tables of measured solar radiation (in Spanish).

Measurements of solar radiation for various regions of Mexico.

Solar radiation atlas of Mexico (b\&w + color).

Modeling methods for estimation of solar radiation (in Spanish).

Estimates of solar radiation for tilted surfaces, tables, graphs, plus two new reports on solar radiation (both include maps).

\section{Geothermal}

MEX-Gl Abstract only, describes geothermal energy development in Mexico.

MEX-G2 Abstract only, describes the Los Azufres Geothermal Field.

MEX-G3 Abstract only, describes results of deep drilling at the Laguna Salada.

\section{General}

MEX-N1

MEX-N2

MEX-N3

Review of technologies and their applications, costs benefits, charts, tables.

Abstract only, discusses renewable sources of energy for rural Mexico.

Detailed review of installed renewable energy systems. 


\section{New Zealand (NZ)}

Wind

NZ-W1 Statistical assessment of wind energy: gusts and turbulence, map, graphs, and charts.

NZ-W2 Abstract only, describes a wind energy survey.

NZ-W3 Abstract only, describes wind energy research.

NZ-W4 Abstract only, describes New Zealand's wind energy potential.

Solar

NZ-S1 Estimation of solar radiation, modelling methods, graphs, tables.

Biomass

NZ-B1

NZ-B2 Discusses power demand and supply, percentages, biomass energy potential, table.

NZ-B3

Describes energy production, discusses the biomass resource potential, output estimates, chart and table.

Geothermal

NZ-G1 Abstract only, discusses a survey of geothermal resource.

Hydro

NZ-H1 Abstract only, describes the use of hydropower as a power supply.

General

NZ-N1

NZ-N2

Abstract only, describes New Zealand's energy policy.

Energy supply and demand, percentages, renewable energies.

\section{Papua New Guinea (PNG)}

\section{Solar}

PNG-S1 Solar radiation measurements, statistical analysis, modeling methods for estimation, tables.

PNG-S2 Describes the pilot radiation observation experiment at Kavieng.

PNG-S3 Methods of estimating solar radiation, tables, graphs, charts.

\section{Geothermal}

PNG-G1 Study of geothermal gases, maps, measurements.

\section{Hydro}

PNG-H1

PNG-H2

PNG-H3

Abstract only, describes a feasibility study for the micro hydro plant in the Enga Province.

General

PNG-N1

$$
\text { Abstract only, discusses advantages of small hydro technology for the country. }
$$

Abstract only, describes a feasibility study on hydro development in western PNG.

PNG-N2 Trip report, identifies key contacts for renewable energy projects, costs, recommendations, includes general information on three South Pacific island nations. 


\section{The Republic of the Philippines (RP)}

Solar

RP-S1 General article, development aspects of PV technology, projects, costs, policy.

Biomass

RP-B1

RP-B2
Abstract only, describes the waste fuel conversion process.

Abstract only, describes a report on various factors associated with growing wood crops.

\section{Geothermal}

RP-G1

RP-G2

RP-G3

RP-G4

RP-G5

RP-G6

RP-G7

Hydro

RP-H1

General article, describes geothermal development and policy in the Philippines.

Not available.

Abstract only, describes a report on geothermal resources of the greater Tongonan field.

Abstract only, describes a study on geothermal reserves on the island of Leyte.

Abstract only, describes an article on general resource development and history of geothermal development of the Tongonan and Palipinon fields.

Abstract only, describes an evaluation of the Tongonan reservoir.

Abstract only, describes geothermal development in the Philippines.

General

RP-G1 Abstract only, describes a market survey for the renewable energies.

\section{Singapore (SIN)}

\section{Solar}

SIN-S1

SIN-S2

SIN-S3

SIN-S4

SIN-S5

Biomass

SIN-B1

Hydro

SIN-H1

General

SIN-N1
Statistical assessment, modeling methods for solar radiation, tables, charts. Measurements of solar radiation, modeling methods, graphs and charts. Measurements of solar radiation, modeling methods, graphs, tables. General article, measurements of solar radiation, modelling methods, tables, graphs, charts.

Measurements of solar radiation, graphs.

Abstract only, describes biomass recovery from pig waste.

Abstract only, describes a general article on developing a major international energy project.

Abstract only, describes a report on formation of the ASEAN, energy situation. 


\section{Chinese Taipei (CT)}

\section{Wind}

CT-Wl Note on wind-diesel system installed on the island of Chi-Mei.

Solar

CT-S1 Abstract only, overview of solar thermal energy systems development.

Biomass

CT-B l Abstract only, describes efforts to develop certain forest species.

\section{Hydro}

CT-Hl

CT-H2
Abstract only, describes a paper on algorithm designed for solving hydroelectric generation scheduling problem.
Abstract only, describes a report on hydroelectric projects around the world.

\section{Geothermal}

CT-Gl

General

CT-Nl

CT-N2

CT-N3

Abstract only, describes geothermal distribution in China.

\section{Thailand (THA)}

\section{Wind}

THA-Wl
Economic issues and energy policy, technology overview and evaluation.

Abstract only, describes a programme to develop a climate and air-quality station. Abstract only, describes energy supply and demand, percentages, climate.

\section{Solar}

THA-S1

THA-S2

THA-S3

THA-S4

THA-S5

THA-S6

THA-S7

THA-S8

Abstract only, describes a feasibility study of utilizing wind energy for pumping water and providing electricity.

Biomass

THA-Bl

Abstract only, describes results of comparison of statistical methods. Measurements of solar radiation, modeling methods, graphs, charts.

Evaluation of PV grid-connected system, technology description, tables, graphs, charts, pictures.

Abstract only, describes PV technology development, water-pumping applications. Abstract only, describes PV technology development, water-pumping applications. Measurements of solar radiation, modeling methods, tables, graphs.

Modelling methods for estimating solar radiation, graphs, table of comparison between methods.

Measurements of solar radiation, modeling methods, maps, tables, graphs.

\section{Hydro}

THA-Hl

THA-H2

THA-H3

Abstract only, describes results of harvesting equipment modifications, costs.

Abstract only, discusses small-scale hydro systems.

Abstract only, describes Thailand cooperation with Laos on hydro projects. Abstract only, discusses repercussions of damming of the Lower Mekong. 


\section{General}

THA-N1

THA-N2

THA-N3

THA-N4

THA-N5

THA-N6

THA-N7

THA-N8
Abstract only, describes Thailand's economic condition.

Abstract only, describes a study on effects of abatement strategies, percentages.

Abstract only, describes a report on Thailand's power sector.

Abstract only, describes dam projects in South China Sea.

Abstract only, describes an article on alternative energy sources.

Abstract only, describes Thailand's economic conditions.

Abstract only, describes energy generation prospects, percentages.

Describes energy industry, economic conditions, percentages, supply and demand equations, tables, scenarios.

\section{The United States of America (US)}

\section{Wind}

US-W1

US-W2

US-W3

US-W4

\section{Solar}

US-S 1

US-S2

US-S3

US-S4

US-S5

US-S6

US-S7

US-S8

US-S9

US-S 10

US-S 11

\section{Biomass}

US-B1

US-B2

US-B3

US-B4

US-B5

US-B6

US-B7
Comprehensive atlas of the U.S., includes detailed maps, measured data.

Wind data assessment and models, detailed maps.

Wind potential analysis, includes a synthesized map, several studies published.

Comprehensive paper on wind potential, includes detailed maps (similar to US-W1).

Comprehensive solar radiation data, measured and modeled, tables, graphs, charts. Insolation measurements, direct normal radiation measurements, tables.

Detailed solar radiation maps (color).

Typical meteorological year solar radiation values; available on CD-ROM, tables.

Solar radiation values applied to buildings, tables, graphs, charts.

Solar radiation values applied to Flat-Plate and Concentrating Collectors, tables, graphs, charts.

Measured and modeled data, tables.

Describes solar radiation monitoring networks.

Solar radiation measurements, hourly data, tables.

Comprehensive atlas of solar energy resources, maps.

A general book on several sources of renewable energy, includes maps, tables, graphs and charts.

Biomass resource assessment for the Tennessee Valley region.

Biomass resource assessment for the State of Washington.

Comprehensive study of MSW resource and management.

Measurements of biomass energy resource and its potential.

Assessment and estimation of MSW's potential as an energy source.

Describes the MSW resource in the U.S.

Describes the physical and chemical properties of MSW.

\section{Geothermal}

US-G1

Study of geothermal resource at the Desert Peak Geothermal Field.

US-G2 Comprehensive study of geothermal resource in the U.S., measurements, estimations.

\section{Hydro}

US-H1

Assessment of hydropower, estimations, tables. 
US-H2 Estimations of hydropower potential.

US-H3 Methods for estimating the hydro resource.

US-H4 Global assessment of hydro resource, maps, stations location.

US-H5 Comprehensive study of hydroelectric power resources.

US-H6 Describes the budgeting issues of hydroelectric power.

\section{General}

US-N1 A comprehensive study of the major renewable energy sources: measurement methods, development, and resource size, includes extensive bibliography.

US-N2 A comprehensive study of the major renewable energy sources in U.S. and U.K., includes maps, tables, graphs and charts.

\section{Southeast Asia Region (SE) (General Category, information on many APEC economies)}

\section{Solar}

SE-S1

Printout of International Solar Radiation Database, measured data tables for most of APEC countries, detailed listing by site, coordinates.

\section{General}

SE-N1

Overview of energy resources of the developing Asian countries, includes tables of renewable energy potential, supply and demand, consumption, projects, factors involved in R\&D.

SE-N2 Economic and financial issues and renewable energy discussion.

SE-N3 Overview of energy industry in ASEAN, demand and supply, tables, percentages, graphs, charts, scenarios. 
APEC \#98-RE-01.1 